EFEITO DA PRESENÇA DO VÍRUS DO “VIRA-CABEÇA” DO TOMATEIRO E DE
RIBAVIRINA SOBRE A CINÉTICA DE CRESCIMENTO DE PROTOPLASTOS DO
MESÓFILO DE FUMO (Nicotiana tabacum L.) EM CULTIVO DE SUSPENSÃO E SOBRE ISOFORMAS DE PEROXIDASES, SHIQUIMATO DESIDROGENASES E AMILASES.

VERA MARIA QUECINI

Engenheira Agrônoma

Orientador : Prof. Dr. DARCY MARTINS DA SILVA

Dissertação apresentada à Escola Superior de Agricultura "Luiz de Queiroz", da Universidade de São Paulo, para a obtenção do título de Mestre em Agronomia, Área de Concentração : Microbiologia Agrícola.

P I R A C I C A B A

Estado de São Paulo - Brasil

Abril - 1995 


\section{Quecini, Vera Maria}

Q3e Efeito da presença do vírus do "vira-cabeça" do tomateiro e de ribavirina sobre a cinética de crescimento de protoplastos do mesófilo de fumo (Nicotiana tabacum L.) em cultivo de suspensão e sobre isoformas de peroxidases, shiquimato desidrogenases e amilases. Piracicaba, 1995.

134p. ilus.

Diss. (Mestre) - ESALQ

Bibliografia.

1. Inibidor de crescimento 2. Izoenzima vegetal 3. Planta hospedeira - Atividade enzimática 4. Planta hospedeira - Doença Controle químico 5. Protoplasto vegetal - crescimento 6. Viracabeça do tomateiro 7. Vírus fitopatogênico - Inibidor de crescimento I. Escola Superior de Agricultura Luiz de Queiroz, Piracicaba 
EFEITO DA PRESENÇA DO VÍRUS DO “VIRA-CABEÇA" DO TOMATEIRO E DE RIBAVIRINA SOBRE A CINÉTICA DE CRESCIMENTO DE PROTOPLASTOS DO MESÓFILO DE FUMO (Nicotiana tabacum L.) EM CULTIVO DE SUSPENSÃO E SOBRE ISOFORMAS DE PEROXIDASES, SHIQUIMATO DESIDROGENASES E AMILASES.

VERA MARIA QUECINI

Aprovada em 15.05.95

Comissão Julgadora

Prof. Dr. Darcy Martins da Silva ESALQ/USP

Prof. Dr. Luiz Gonzaga do Prado Filho ESALQ/USP

Prof. Dr. Jorge Rezende ESALQ/USP

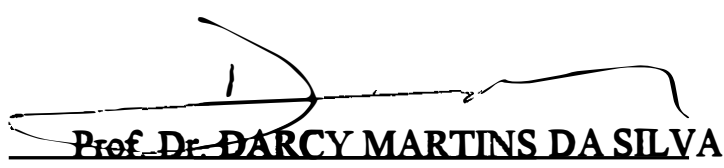

Orientador 
⿶6

Creio, perante a evoluçãa imensa,

Que o homem universal de amanhã vença

O homem particular eu que ontem fui !"

Augusto dos Anjos

Para minha família e amigos

Dedico 


\section{AGRADECIMENTOS}

Às seguintes instituições que possibilitaram a realização deste trabalho :

- Escola Superior de Agricultura "Luiz de Queiroz" da Universidade de

São Paulo,

- Departamento de Química, Setor de Bioquímica da ESALQ /USP e todos os funcionários e professores pelo auxílio e amizade,

- CAPES pela bolsa concedida durante o período de mestrado,

- $\quad$ FAPESP pelo auxílo à pesquisa que possibilitou a execussão do trabalho

prático.

Ao meu orientador Prof. Dr. Darcy Martins da Silva.

Aos meus colegas do laboratório : Flávia T.H. Pacheco, Iracema Y. Horibe, Maria das Graças Ongarelli e Mário Lúcio Lopes.

$\mathrm{E}$, especialmente, aos meus amigos e à minha familila. 


\section{SUMÁRIO}

Página

LISTA DE FIGURAS .................................................................. viii

LISTA DE TABELAS …................................................................. xii

LISTA DE ABREVIATURAS E SÍMBOLOS........................................... xiii

RESUMO …..............................................................................

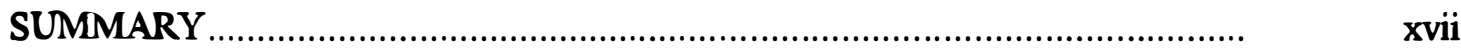

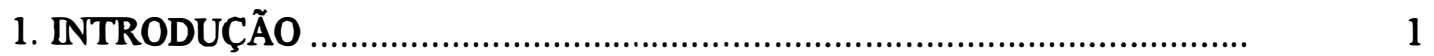

2. REVISÃO DE LITERATURA ….................................................. 4

2.10 vírus do "vira-cabeça" do tomateiro (VVCT)............................... 4

2.1.1 Distribuição Geográfica e Sintomatologia.......................... 4

2.1.2 Morfologia, Morfogênese e Multiplicação........................... 6

2.1.3 Classificação e Caracterização Molecular ......................... 8

2.1.4 Citopatologia e Efeitos da Presença do VVCT sobre o

hospedeiro.

2.1.5 Estratégias de Controle ............................................. 14

2.2 Uso de Protoplastos em Virologia .............................................. 15

2.3 Substâncias Antivirais.............................................................. 22

2.3.1 Substâncias Antivirais e seu Uso................................. 22

2.3.2 Ribavirina ou Virazole ou 1- $\beta$-D-ribofuranosil-1,2,4

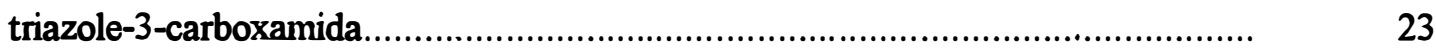

2.4 Cinética de Crescimento de Cultivos de Células em Suspensão........... 26

2.5 Alterações Protéicas devido a Patógenos...................................... 32

2.5.1 Considerações Gerais.................................................... 32 
2.5.2 Peroxidases............................................................... 34

2.5.3 Shiquimato Desidrogenases................................................. 36

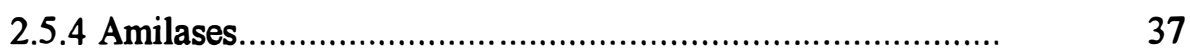

3. MATERIAL E MÉTODOS.....................................................................

3.1 Material Vegetal............................................................................

3.1.1 Hospedeiras Utilizadas.................................................. $\quad 39$

3.1.2 Condições de Manutenção das Hospedeiras.......................... 40

3.2 Inoculação do VVCT em Plantas Hospedeiras...................................... 40

3.3 Aplicação de Ribavirina.....................................................................

3.4 Obtenção e Cultivo de Protoplastos....................................................

3.4.1 Protoplastos do Mesófilo de fumo (Nicotiana tabacum L.).. $\quad 42$

3.4.2 Avaliação da Cinética de Crescimento dos Protoplastos em

Cultivo de Suspensão

3.5 Extração das Proteínas Totais Solúveis da Parte Aérea das Hospedeiras

3.5.1 Proteinas Armazenadas sob Congelamento

3.5.2 Proteinas Cruas.

3.6 Eletroforese das Proteínas Solúveis Totais em Gel de Poliacrilamida (PAGE) e de Poliacrilamida e Amido.

3.7 Coloração das Peroxidases, Shiquimato Desidrogenases e Amilases nos Géis.

3.7.1 Peroxidases. 
3.8 Impressão das Proteínas do Tecido Vegetal em Membranas de Nitrocelulose ("tissue-blot").

3.9 Coloração das Peroxidases, Shiquimato Desidrogenases e Amilases Impressas sobre Membranas de Nitrocelulose.

4.1 Cinética de Crescimento de Protoplastos em Cultivo de Suspensão.....

4.1.1 Método Direto.

4.1.2 Métodos Indiretos.

4.2 Reutilização de Enzimas Líticas na Obtenção de Protoplastos...

4.3 Perfis Eletroforéticos de Peroxidases, Shiquimato Desidrogenases e Amilases

4.3.1 Peroxidases.

4.3.2 Shiquimato Desidrogenases...

4.3.3 Amilases.

4.4 Atividade de Peroxidases, Shiquimato Desidrogenases e Amilases nas Membranas de Nitrocelulose.

4.4.1 Peroxidases.

4.4.2 Shiquimato Desidrogenases.

4.4.3 Amilases.

5.1 Efeito da Presença de VVCT e de Ribavirina sobre a Cinética de Crescimento de Protoplastos em Suspensão in vitro.

5.1.1 Métodos Indiretos.

5.1.2 Método Direto. 
5.2 Efeito da Presença de VVCT e de Ribavirina sobre Isoformas de Peroxidases, Shiquimato Desidrogenases e Amilases........................................ 82

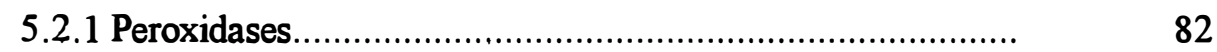

5.2.2 Shiquimato Desidrogenases..................................... 84

5.2.3 Amilases............................................................ 84

5.3 Reutilização de Enzimas Líticas na Obtenção de Protoplastos............. 85

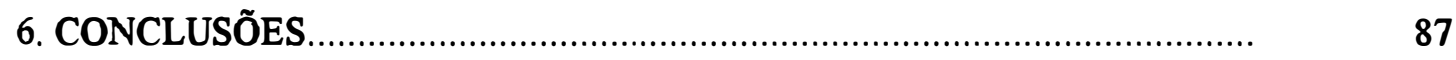

REFERÊNCIAS BIBLIOGRÁFICAS.................................................... 89



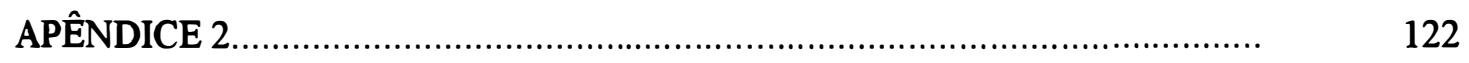

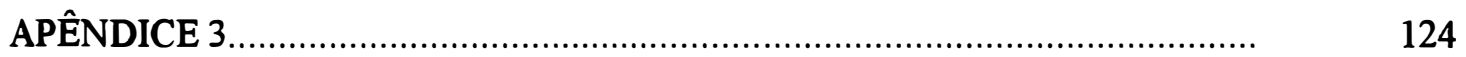




\section{LISTA DE FIGURAS}

Figura

Página

01 - Estrutura e estratégia de expressão gênica do VVCT, segundo RESENDE (1993)

02 - Diagrama esquemático do posicionamento dos frascos erlenmeyer e da posição dos protoplastos (pontos) durante a medida de $\mathbf{W}$

03 - (A) Vista frontal e (B) visa lateral do posicionamento dos erlenmeyers para a leitura do comprimento $\mathbf{W}$ da corda formada pelos protoplastos precipitados. A inclinação constante permite a obtenção da reta de calibração

04 - Curvas de crescimento de protoplastos de mesófilo de Nicotiana tabacum sadios, infectados com VVCT e infectados e tratados com ribavinina em cultivo de suspensão representadas como contagens obtidas pelo método direto

05 - Curvas de crescimento de protoplastos de mesófilo de Nicotiana tabacum sadios, infectados com VVCT e infectados e tratados com ribavirina em cultivo de suspensão, representadas como regressão linear com transformação logarítmica das contagens obtidas pelo método direto

06 - Densidade óptica (descontando-se o valor da dispersão luminosa) do cultivo de protoplastos : sadios (S), doente (D), sadio + ribavirina $(\mathbf{S}+\mathbf{R})$ e doente + ribavinina (D+R) 
07 - Curvas de crescimento de protoplastos de mesófilo de Nicotiana tabacum sadios, infectados com VVCT e infectados e tratados com ribavirina em cultivo de suspensão, representadas como medidas do valor $\mathrm{W}$

08 - Curvas de crescimento de protoplastos de mesófilo de Nicotiana tabacum sadios, infectados com VVCT e infectados e tratados com ribavirina em cultivo de suspensão, representadas como regressão linear das medidas do valor W

09 - Comparação gráfica entre as equações de regressão linear com transformação logarítmica para o material obtido a partir de enzima reutilizada e de não-reutilizada, realizada com base no método direto (contagem ao microscópio óptico)

10 - Comparação gráfica entre as equações de regressão linear para o material obtido a partir de enzima reutilizada e de não-reutilizada, realizada com base no método indireto (medida do valor $\mathrm{W}$ )

11 - (A) Perfil eletroforético em gel de poliacrilamida das isoperoxidases totais solúveis nos extratos de folha de tomate (Lycopersicon esculentum Mill.) e fumo (Nicotiana tabacum L.) e sua representação esquemática (B)

12 - (A) Perfil eletroforético em gel de poliacrilamida das isoperoxidases totais solúveis nos extratos de folha de tomate (Lycopersicon esculentum Mill.) e petúnia (Petunia hybrida Vilm.) e sua representação esquemática (B) 
13 - Perfil eletroforético em gel de poliacrilamida de isoshiquimato desidrogenases totais solúveis nos extratos de folha de tomate (Lycopersicon esculentum Mill.) e petúnia (Petunia hybrida Vilm.)

14 - (A) Perfil eletroforético em gel de poliacrilamida de isoshiquimato desidrogenas solúveis totais nos extratos de folha de tomate (Lycopersicon esculentum Mill.) e fumo (Nicotiana tabacum L.) e sua representação esquemática (B)

15 - (A) Perfil eletroforético em gel de poliacrilamida de isoshiquimato desidrogenas solúveis totais nos extratos de folha de petúnia (Petunia hybrida Vilm.) e sua representação esquemática (B).

16 - Perfil eletroforético em gel de poliacrilamida e amido de isoamilases solúveis totais nos extratos de folha de fumo (Nicotiana tabacum $\mathrm{L}$.)

17 - Perfil eletroforético em gel de poliacrilamida e amido de isoamilases totais solúveis nos extratos de folha de tomate (Lycopersicon esculentum Mill.) e petúnia (Petunia hybrida Vilm.).

18 - "Tissue-blot"em membrana de nitrocelulose (B) de folha de petúnia (Petunia hybrida Vilm.) infectada com VVCT (A) para isoperoxidases

19 - "Tissue-blot"em membrana de nitrocelulose (B) de folha de petúnia (Petunia hybrida Vilm.) sadia (A) para isoperoxidases

20 - "Tissue-blot"em membrana de nitrocelulose (B) de folha de fumo (Nicotiana tabacum L.) infectada com VVCT (A) para isoperoxidases 
21 - "Tissue-blot"em membrana de nitrocelulose (B) de folha de fumo (Nicotiana tabacum $\mathbf{L}$.) sadia (A) para isoperoxidases

22 - "Tissue-blot"em membrana de nitrocelulose (B) de folha de tomate (Lycopersicon esculentum Mill. ) infectada com VVCT (A) para isoperoxidases .

23 - “Tissue-blot"em membrana de nitrocelulose (B) de folha de tomate (Lycopersicon esculentum Mill. ) sadia (A) para isoperoxidases

24 - “Tissue-blot"em membrana de nitrocelulose (B) de folha de petínia (Petunia hybrida Vilm.) infectada com VVCT (A) para isoshiquimato desidrogenases.......

25 - “Tissue-blot"em membrana de nitrocelulose (B) de folha de petúnia (Petunia hybrida Vilm.) sadia (A) para isoshiquimato desidrogenase

26 - "Tissue-blot"em membrana de nitrocelulose (B) de folha de fumo (Nicotiana tabacum L.) infectada com VVCT (A) para isoamilases, reveladas de acordo com procedimento proposto por WAGIH (1992)

27 - "Tissue-blot"em membrana de nitrocelulose (B) de folha de tomate (Lycopersicon esculentum Mill.) infectada com VVCT (A) para isoamilases, reveladas de acordo com procedimento proposto por VALLEJOS (1983) 


\section{LISTA DE TABELAS}

Tabela

Página

01 -Equações de regressão linear com transformação loganitmica, coeficiente de correlação e significância estatística da regressão para 0 crescimento de protoplastos de mesófilo de Nicotiana tabacum em suspensão in vitro, avaliado pelo método direto

02 - Comparação dos contrastes de médias através do teste $\mathrm{F}$ para todos os tratamentos a nível de $95 \%$ de probabilidade, avaliados pelo método direto

03 - Equações de regressão linear, coeficiente de correlação e significância estatística da regressão para o crescimento de protoplastos de mesófilo de Nicotiana tabacum em suspensão in vitro, avaliado pelo método indireto da medida do valor $\mathrm{W}$

04 - Comparação dos contrastes de médias através do teste $\mathrm{F}$ para todos os tratamentos a nível de $95 \%$ de probabilidade, avaliados pelo método indireto da medida do valor $\mathrm{W}$

05 - Comparação entre parâmetros estatísticos para o material obtido a partir de enzima reutilizada e de não-reutilizada, realizada com base no método direto

06 - Comparação entre parâmetros estatísticos para o material obtido a partir de enzima reutilizada e de não-reutilizada, realizada com base no método indireto (medida do valor $\mathrm{W}$ ) 


\section{LISTA DE ABREVIATURAS}

A - adenina nucleotídeo

A - termo independente das equações de regressão estatística (constante)

aa - aminoácido

ANA - ácido naftaleno acético

B - coeficiente de regressão estatística (termo dependente)

6-BAP - 6-benzilamino purina

C - sentido complementar ao RNA viral

$\mathrm{cm}$ - centímetro

$\mathrm{cm}^{2}$ - centímetro quadrado

cv. - cultivar

C.V. - coeficiente de variação estatística

D - Dalton

kD - kilodalton

2,4 D - ácido 2, 4 diclorofenoxiacético

DNA - ácido desoxirribonucléico

EDTA - ácido etilenodiaminotetriacético

g - grama

kg - kilograma

mg - miligrama

$\mu \mathrm{g}$ - micrograma

ng - nanograma 
$g$ - gravidade

GTP - guanosina 5'- monofosfato

h - hora

min. - minuto

s - segundo

HMP - via das hexoses monofosfato

I.C. - intervalo de confiança

L - litro

mL- mililitro

$\mu \mathrm{L}-$ microlitro

$\lambda$ - comprimento de onda

M - molar

$\mathrm{mM}$ - milimolar

m - metro

$$
\begin{aligned}
& \mu \mathrm{m} \text { - micrômetro } \\
& \text { nm - nanômetro }
\end{aligned}
$$

mA - miliampere

2-me - 2-mercaptoetanol

MTT - brometo 3-(14,5-dimetiltiazolil-2-)-2,5-difeniltetrazólio

$\mathrm{N}$ - sentido não-complementar do RNA viral

$\mathrm{NADH}$ - nicotinamida adenina dinucleotídeo reduzida

NADP + - nicotinamida adenina dinucleotídeo fosfato

n - número de dados analisados estatisticamente

n.s. - não-significativo estatisticamente 
nt - nucleotídeo

PAL - fenilalanima-liase

pH - cologarítimo da concentração hidrogeniônica

pi - ponto isoelétrico

PM - peso molecular

PMS - fenazina monossulfato

PVC - acetato de polivinila

q.s.p. - quantidade suficiente para

r - coeficiente de correlação estatística da regressão linear

RNA - ácido ribonucléico

mRNA - ácido ribonucléico mensageiro

tRNA - ácido ribonucléico de transferência

vcRNA - RNA que codifica produto(s) no sentido viral-complementar

vRNA - RNA que codifica produto(s) no sentido viral

RNase - ribonuclease

s - variância estatística da amostra

$s^{2}$ - desvio-padrão estatístico da amostra

SDS - dodecil sufato de sódio

TRIS - N, N, N', N', tetrametil etileno diamina

TSWV - tomato spotted wilt virus

U - uracila nucleotídeo

uv - luz ultravioleta

V - volts

VVCT - vírus do "vira-cabeça" do tomateiro 


\title{
EFEITO DA PRESENÇA DO VÍRUS DO "VIRA-CABEÇA" DO TOMATEIRO E DE \\ RIBAVIRINA SOBRE A CINÉTICA DE CRESCIMENTO DE PROTOPLASTOS DO \\ MESÓFILO DE FUMO (Nicotiana tabacum L.) EM CULTIVO DE SUSPENSÃO E SOBRE \\ ISOFORMAS DE PEROXIDASES, SHIQUIMATO DESIDROGENASES E AMILASES.
}

\author{
AUTORA : VERA MARIA QUECINI \\ ORIENTADOR : Prof. Dr. DARCY MARTINS DA SILVA
}

\section{RESUMO}

O presente trabalho teve como objetivo avaliar o efeito do vírus do "vira-cabeça" do tomateiro e de ribavirina, uma agente antiviral de amplo espectro contra vírus de DNA e RNA, sobre a cinética de crescimento de protoplastos do mesófilo de fumo (Nicotiana tabacum L.) em cultivo de suspensão e sobre formas isoenzimáticas de peroxidases, shiquimato desidrogenases e amilases em hospedeiros que exibem sintomas sistêmicos e hipersensibilidade.

Os métodos direto e indiretos revelaram que o vírus interferiu preferencialmente sobre o número inicial de protoplastos viáveis (inóculo inicial) e a ribavirina teve efeito negativo sobre a velocidade de crescimento do cultivo de protoplastos em suspensão, mostrando que, nestas condições, sua ação não foi seletiva sobre a replicação viral.

A ribavirina não reverteu os perfis eletroforéticos da isoperoxidases e isoshiquamto desidrogenases do material doente tratado aos perfis obtidos para o material sadio. O virus e o tratamento com ribavirina não alteraram o perfil das isoamilases. Estudos in situ mostraram a associação de maior atividade de isoperoxidases aos sintomas cloróticos e necróticos presentes nas folhas. 
EFFECTS OF "VIRA-CABEÇA" VIRUS AND RIBAVIRIN ON THE GROWTH KINETICS

OF TOBACCO (Nicotiana tabacum L.) MESOPHYLL PROTOPLASTS IN SUSPENSION

CULTURE AND ON ISOFORMS OF PEROXIDASE, SHIKIMATE DEHYDROGENASE

AND AMYLASES.

AUTHOR : VERA MARIA QUECINI

ADVISER : Prof. Dr. DARCY MARTINS DA SILVA

\section{SUMMARY}

The actual research work aimed to evaluate the effects of "vira-cabeça" virus (Brazilian tomato spotted wilt virus) and ribavirin, a broad spectnum antiviral against DNA and RNA virus, on the growth kinetics of tobacco (Nicotiana tabacum L.) mesophyll protoplasts in suspension culture and on peroxidase, shikimate dehydrogenase and amylase isozymes from systemic-symptom and hypersensible (local lesion) hosts.

Both direct and indirect methods employed showed the preferential virus action on the initial viable protoplast number (initial inoculum) and also that ribavirin induced a negative effect on the growth rate of the suspension culture, which has proved that under these conditions, its action was not selective to virus replication.

Ribavirin was also unable to revert the electrophoretic isoperoxidase and isoshikimate dehydrogenase profiles from infected and antiviral-treated tissue to those from healthy tissues. Both the virus and ribavirin treatment did not induce any alterations on isoamylase profiles. In situ studie showed the association of higher peroxidase activities to chlorotic and necrotic symptoms on the leaves. 


\section{INTRODUÇÃO}

Um dos principais causadores de prejuizos em hortaliças nas regiões tropicais é, atualmente, o vírus do vira-cabeça do tomateiro (VVCT), conhecido internacionalmente como "Tomato spotted wilt virus - TSWV". A distribuição do VVCT se limitava às regiões tropicais, mas recentemente devido à expansão da área atacada pelo seu principal inseto-vetor (Frankliniella occidentalis, Perg.) este vírus passou a apresentar prejuízos consideráveis também em áreas de clima temperado e subtropical.

O VVCT só recebeu maior atenção quanto à sua classificação e taxonomia mais recentemente, devido ao aumento de pesquisas quanto às suas características moleculares. Assim, até pouco tempo atrás a sua posição taxonômica era muito contraditória. Atualmente, aceita-se que o VVCT seja membro de uma família de vírus animais chamada Bunyaviridae, sendo considerado como pertencente ao grupo dos Tospovirus. Diferentemente dos outros membros da família, o VVCT é transmitido apenas por oito espécies de tripes, principalmente do gênero Frankliniella , e o seu espectro de hospedeiros se limita às plantas, não sendo encontrado em outro tipo de hospedeiro, embora se saiba que ele tem capacidade de se multiplicar no inseto-vetor.

Comparando-se com outros vírus de plantas, este vírus apresenta um dos círculos mais amplos de plantas hospedeiras, sendo que muitas delas são de alto valor econômico e de alta importância comercial.

O uso de substâncias capazes de inibir totalmente ou parcialmente o crescimento e a multiplicação de vírus não tem sido muito estudado para tecidos vegetais, enquanto que em virologia médica e veterinária o papel destas substância já está muito melhor definido. Os efeitos provocados por viricidas ou substâncias antivirais sobre o agente patogênico e até sobre o tecido hospedeiro têm igualmente sido mais estudados para animais do que para vegetais, sendo que células animais em cultivo de suspensão ou monocamadas são um meio fácil e adequado para estes estudos, uma vez que o controle é muito maior e a manipulação muito mais cômoda. 
O uso de protoplastos apresenta muitas vantagens no estudo de vírus vegetais uma vez que dispensa grandes áreas para manutenção do grande número de vasos necessário para a condução de qualquer experimento, o controle do ambiente é muito mais preciso tanto dos componentes quimicos quanto das características físicas do meio $(\mathrm{pH}$, temperatura, pressão osmótica, etc.), não há troca de substâncias que normalmente ocorre em tecidos íntegros, sendo que o protoplasto funciona como uma unidade isolada no cultivo em suspensão , semelhante a uma célula bacteriana.

A presença de um agente patogênico no organismo hospedeiro provoca mudanças notáveis em seu metabolismo como resposta à infeção, sendo que o metabolismo protéico é profundamente afetado. Assim, a maior eficiência do patógeno em colonizar o hospedeiro dependerá dos mecanismos de defesa dos quais a planta pode dispor.

As alterações metabólicas são utilizadas pelas plantas como uma forma de defesa contra o ataque de patógenos, de modo que podem ocorrer alterações na atividade e na quantidade de enzimas do metabolismo primário e secundário, levando à resistência ou reduzindo a susceptibilidade da planta a um dado fitopatógeno.

Existem várias enzimas relacionadas à patogênese, sendo que podemos destacar : a peroxidase, que participa de vários processo metabólicos de grande importância como a oxidação de fenóis e a biossíntese de etileno; as hidrolases, principalmente as ácidas, que tem um papel de osmorregulação em processos de patogênese, destacando-se atualmente as pesquisas referentes às amilases.

Caracteristicamente, além de outras alterações metabólicas, o VVCT provoca a fluorescência das áreas vizinhas às lesões locais de plantas infectadas, isto é devido ao acúmulo de uma substância denomina escopoletina, proveniente de precursores comuns à via biossintética dos aminoácidos aromáticos (via do ácido shiquímico), o que parece indicar alguma perturbação nesta via.

Assim, considerando estes fatores, o presente trabalho tem como objetivos :

1) Estudar os efeitos do vírus do vira-cabeça do tomateiro e de um agente viricida (ribavirina) sobre a cinética de crescimento de protoplastos vegetais em cultivo de suspensão através de dois métodos de avaliação : um envolvendo a contagem direta dos protoplastos e o outro utilizando-se parâmetros indiretos. 
2) Verificar as alterações apresentadas nos perfis de três isoenzimas (peroxidase, amilase e shiquimato desidrogenase) relacionadas à presença do VVCT em hospedeiros com diferentes tipos de. reação à presença do vírus : fumo (Nicotiana tabacum,L.) e tomate (Lycopersicon esculentum, Mill.) de reação sistêmica e petúnia (Petunia hybrida Vilm.) hipersensível (lesão local).

3) Comparar os métodos direto e indireto na avaliação da cinética de crescimento de protoplastos em suspensão, bem como a reutilização das enzimas líticas consumidas na hidrólise enzimática para a liberação dos protoplastos dos tecidos íntegros. 


\section{REVISÃO BIBLIOGRÁFICA}

\subsection{Vírus do "Vira-cabeça" do Tomateiro (VVCT)}

\subsubsection{Distribuição Geográfica e Sintomatologia}

\subsubsection{Distribuição Geográfica}

A doença do "“"vira-cabeça" " do tomateiro foi primeiramente encontrada na Austrália em 1915, mas só posteriormente foi identificada como possuindo um agente causal virótico (FRANCKI \& HATTA, 1981).

Após a descoberta do agente causal desta doença, identificado como TSWV (Tomato Spotted Wilt Virus), começou o seu reconhecimento em várias partes do mundo em diversas culturas de interesse econômico (REDDY et al., 1991).

Incluem-se grupos extensos de plantas como hospedeiros do VVCT, totalizando em tomo de 500 espécies vegetais, englobando dicotiledôneas e monocotiledôneas dentro de aproximadamente 70 familias botânicas (ÁVILA, 1992).

A distribuição do VVCT é cosmopolita, não tendo restrição quanto a clima. Trabalhos atuais mostram a presença deste vínus em hortaliças (RAO et al., 1987; REDDICK et al., 1987; LIMA \& SOUZA, 1988; HALLIWELL \& JOHNSON, 1988; PATTERSON et al., 1989; TRAD et al., 1992; ZIMMER \& HABER, 1992) em locais tão climática e geograficamente distintos quanto Índia, Estados Unidos, Brasil, Espanha e Canadá.

Além de hortaliças o VVCT tem sido um grande problema em culturas de casa de vegetação no Canadá (BROADBENT et al., 1987; MATTEONI et al., 1988), no estado de Oregon nos Estados Unidos (GREEN et al., 1988), em plantas omamentais e orquídeas (GOFFLOT \& VERHOVEN, 1990; HU et al., 1992; HAUSBECK et al., 1992; VAIRA et al., 1992) em regiões tropicais e temperadas. 
Em culturas de campo, também tem sido relatada recentemente a presença do VVCT (IWAKI et al., 1984; HOKAMA \& TOKAHASHI, 1987; JAYASENA et al., 1988; MAOKA \& USUGI, 1991; CULBREATH et al., 1992; VAIRA et al., 1993).

Em condições naturais, os vetores deste vírus são os tripes (Thysanoptera); principalmente Thrips tabacci, Frankliniella schultze, F. occidentalis, F. fusca, Scirtothrips dorsalis, Thrips palmi e T. setosus, que possuem poucos métodos eficientes de controle, assim a presença do vírus em regiões muito distintas climaticamente e afastadas geograficamente é perfeitamente compreensível.

A transmissão do VVCT pelos tripes dá-se de uma maneira circulativa e propagativa. 0 vetor parece ser capaz de adquirir o vírus apenas durante o seu estágio larval e tomar-se infectivo apenas mais futuramente no seu ciclo de vida (RESENDE, 1993). A presença deste vírus pode ser detectada em tripes através de ELISA (Enzyme-Linked Immunosorbent Assay) (CHO et al., 1988).

A multiplicação deste vínus em tripes foi provada por WIJKAMP et al. (1993), em trabalho que estuda as interações dos Tospovirus com seu inseto-vetor.

É importante que se observe a ocorrência do VVCT em uma grande variedade de plantas de alto valor comercial e que requerem grande investimento para sua produção.

A ocorrência de reservatórios naturais deste vírus em plantas daninhas também facilita a disseminação da doença por regiões geograficamente extensas (KOBATAKE et al., 1984; SCHUSTER \& HALLIWELL, 1994).

No Brasil, o VVCT é, atualmente, o vírus de maior importância econômica em hortaliças (ÁVILA, 1992). Estando presente também em solanáceas selvagens que servem como reservatório natural deste patógeno (BARRADAS et al., 1982) e em Capsicum sp. (BOITEUX et al., 1993).

\subsubsection{Sintomatologia}

Em condições experimentais o VVCT é usualmente propagado via transmissão mecânica, o que causa mudanças fenotípicas no vírus, entre elas podemos mencionar o acúmulo de partículas incompletas nas células infectadas, o que leva a uma atenuação dos sintomas nas plantas hospedeiras. 
Esta característica é comum aos vírus de RNA negativo, quanto transmitidos sob alta pressão de inóculo (IE, 1982; VERKLEIJ \& PETERS, 1983; RESENDE, 1993). Assim, os sintomas provocados pelo VVCT podem ser variados de acordo com as condições de transmissão.

As condições ambiente, o hospedeiro e a estirpe do vírus utilizados podem afetar a sintomatologia do VVCT.

Um resumo das respostas sintomatológicas de diversos hospedeiros a sete diferentes estirpes deste vírus é apresentado por ÁVILA (1992), mostrando que há grande variedade nos sintomas devido à estirpe.

Freqüentemente são usados como hospedeiros para diagnose, as plantas que apresentam resposta necrótica localizada ao VVCT, como por exemplo o caupi (Vigna unguiculata (L.) Walp ) e a petúnia (Petunia hybridia Vilm.) (REDDY et al., 1991), também mencionando Nicotiana glutinosa $\mathrm{L}$. como um hospedeiro diferencial. Mais recentemente, BARRADAS \& FERRARI (1992) apresentam as vantagens do uso de Petunia integrifolia var. integrifolia como hospedeira que apresenta sintomas característicos.

Baseando-se em estudos recente (ÁVILA, 1992; RESENDE, 1993) que destacam a grande variabilidade sintomatológica provocada por diferentes estirpes ou por mutantes defectivos do VVCT, parece pouco eficiente o uso de sintomas em hospedeiros diferenciais para a diagnose deste vírus. No entanto, devido às facilidades deste método quando comparado com outros mais minuciosos, entende-se que em condições de campo a sua utilização ainda seja viável.

\subsubsection{Morfologia, Morfogênese e Multiplicação}

\subsubsection{Morfologia}

Os primeiros trabalhos de observações e caracterização das partículas do VVCT ao microscópio eletrônico foram feitos nos anos sessenta. KITAJIMA (1965) analisou seções ultrafinas de material de folha e de raiz infectados e propôs que o espalhamento da infecção se deve à passagem de material infeccioso ou mesmo não-infeccioso pelos plasmodesmatas ao invés da partícula completa, uma vez que esta é maior do que o lúmem da plasmodesma.

Estudos referentes à morfologia das partículas intactas do VVCT também foram realizados por KAMMEN et al. (1966). 
Posteriormente a estes trabalhos, o estudo da morfologia das partículas do VVCT evoluiu muito, sendo que os trabalhos mais significativos estão mencionados em revisão feita por BEST (1968).

As caracterizações da partícula virótica, apresentam-nas como partículas aproximadamente esféricas de $85 \mathrm{~nm}$ a $110 \mathrm{~nm}$ de diâmetro, sendo este valor confirmado por muitas observações (CORNUET, 1987). No entanto, a forma da partícula pode diferir ligeiramente de uma estime a outra (BEST, 1968).

FRANCKI \& HATTA (1981) afirmarn que nem sempre os resultados de "leaf-dip" para a observação de partículas de VVCT são consistentes, uma vez que as partículas envelopadas que saem da célula e se espalham sobre a grade do microscópio eletrônico tendem a se achatar e tomar-se distorcidas.

Exames ao microscópio eletrônico de seções delgadas de tecido foliar infectado revelam que a partícula do virus está associada ao retículo endoplasmático (KITAJMA, 1965; NOGUEIRA \& SILVA, 1982). Sendo que várias partículas do vírus são freqüentemente vistas agrupadas na cistema desta organela.

A presença de inclusões citoplasmática adicionais : material granular densamente corado e feixes de filamentos longos foi apresentada por FRANCKI \& GRIVELL (1970).

KITAJIMA et al.(1992a e b) identificaram agregados de nucleocapsídeos do VVCT que se assemelham a novelos de lã e que podem servir como identificação destes agrupamentos viróticos.

\subsubsection{Morfogênese}

Nos estágios primários da infecção das células com o VVCT, a aparência do vírus ao microscópio eletrônico é de um material eletrodenso presente no citoplasma ( KITAIMA, 1965; MILNE, 1970; FRANCKI \& GRIVELL, 1970).

No interior deste material, as partículas imaturas são envolvidas completamente por envelopes duplos, sendo que a sua formação também pode dar-se por brotamento. Posteriormente, apenas as partículas maduras e já envelopadas são observadas. Estas partículas localizam-se no interior de vesículas ou cisternas individuais, formadas provavelmente pela coalescência do envelope extemo e individual das partículas imatura (MILNE, 1970). 
Os estágios de desenvolvimento das partículas de VVCT a partir de poucos momentos após a infecção até a formação de uma nova partícula madura foram acompanhados em estudo ao microscópio eletrônico realizado por IE (1971).

\subsubsection{Multiplicação}

O mecanismo de multiplicação do VVCT foi inicialmente estudado por BALD (1964, 1966). Posteriormente, estes trabalhos foram complementados por KITAJIMA (1965), mostrando que a síntese do vírus inicia-se no nucléolo e que o RNA e a proteína do vírus são unidos no citoplasma associado ao retículo endoplasmático.

A sintese de RNA viral está localizada no nucléolo e no citoplasma (NOGUEIRA et al., 1972). Sendo que estudos posteriores indicam apenas um sítio especial de biossíntese das partículas no núcleo em associação ao retículo endoplasmático disperso por toda a célula (SILVA \& NOGUEIRA, 1980; NOGUEIRA \& SILVA, 1982).

A expressão das proteínas codificadas pelo material genético deste virus ainda está sendo objeto de estudos (KORMELINK et al., 1994).

\subsubsection{Classificação e Caracterização Molecular}

\subsubsection{Classificação}

A classificação do VVCT sempre foi controvertida, devido às características peculiares apresentadas por este vírus.

MILNE \& FRANCKI (1984) agruparam características moleculares (proteínas e ácido nucléico), físicas e epidemiológicas indicando que o VVCT possuía mais semelhanças do que diferenças com relação à familia Bunyaviridae, de vírus que afetam vertebrados, apesar de apenas se conhecer hospedeiros vegetais deste vírus.

Usando vários tipos de ELISA ("Enzyme-Linked Immunosorbent Assay") e hibridações por "Westem blot", WANG et al. (1992) mostram a semelhança do vírus do "“cira-cabeça"” do tomateiro com os Phlebovirus, também membros da família Bunyaviridae, mas que possuem apenas hospedeiros vertebrados. Atualmente sabe-se também que ele também tem a capacidade de multiplicar-se nos tripes (WUKAMP et al., 1993). 
Até pouco tempo, acreditava-se que o VVCT era o único membro do grupo dos Tospovirus, na familia Bunyaviridae (DAVIES, 1985). Mas atualmente já são conhecidos outros membros deste grupo : TCSV ("tomato chlorotic spot virus"), INSV ("impatiens necrotic spot virus") e GRSV ("groundnut spot virus").

\subsubsection{Caracterização Molecular}

\section{a) $\mathbf{O}$ Ácido Nucléico}

Os estudos inciais sobre a composição e organização do ácido nucléico do VVCT foram conduzidos por KAMMEN et al. (1966), concluindo que este material era RNA. BEST (1968) agrupou dados sobre a composição química deste vírus e concluiu a mesma coísa.

HURK et al. (1977), MOHAMED (1981) e VERKLEIJ et al. (1982) realizaram uma série de estudos posteriores que vieram, coletivamente, a acrescentar mais informações sobre os pesos moleculares e a disposição do RNA deste virus.

Atualmente aceita-se que o genoma do VVCT é constituído de três segmentos de RNA de fita simples, que são denominados :

L RNA ("large RNA") - possui 8897 nucleotídeos, tem polaridade negativa e contém uma única seqüência de leitura aberta (“open reading frame" - ORF) que corresponde a um produto de tradução de $331,5 \mathrm{kD}$, que possivelmente representa a transcritase viral (HAAN et al., 1990; HAAN et al., 1991; KORMELINK et al., 1992 a, b e c).

M RNA ("medium RNA") - possui 4821 nucleotídeos, tem estratégia de codificação "ambisense" e contém duas ORFs. A proteína expressa no sentido viral tem 33,6 kD de peso molecular e é uma proteína não-estrutural, chamada NSm. No sentido complementar ao viral, este segmento codifica uma proteína de $127,4 \mathrm{kD}$ que é o precursor da duas glicoproteínas (G1 e G2) que formam a capa protéica (KORMELINK et al., 1992c).

S RNA ("small RNA") - possui 2916 nucleotídeos e, como o M RNA também tem estratégia de codificação "ambisense" e duas ORFs. A proteína não-estrutural (NSs) de 52,2 kD é codificada no sentido viral e a proteína do mucleocapsídeo é codificada no sentido viralcomplementar (HAAN et al., 1990; HAAN, et al., 1992).

As proteínas codificadas pelas moléculas M e S RNA são expressas através de mRNAs sub-genômicos - transcritos das fitas complementares - e iniciadas por um processo de "capsnatching" (KORMELINK et al., 1992a e b). 
As moléculas S e M RNA terminam muito provavelmente na região central interscistrônica, numa estrutura em grampo ( "RNA hairpin") estável e rica em A-U (HAAN et al., 1990; KORMELINK et al., , 1992c.).

Todos os três RNAs genômicos têm terminais 3' e 5' complementares que podem estar dobrados em uma estrutura estável (tipo "panhandle"), sendo que esta estrutura estaria envolvida na formação de nucleocapsídeos pseudo-circulares (PETERS et al., 1991; HAAN et al., 1991; KORMELINK et al., 1992b).

A organização molecular e a estratégia de codificação do RNA do VVCT estão apresentadas na figura 1.

A presença de segmentos complementares a três moléculas de RNA genôtnico foi identificada por TSUDA et al. (1992) em material isolado de nuclecapsídeos deste vírus, concordando com observações feitas pelos pesquisadores anteriormente mencionados.

RESENDE (1993) caracterizou segmentos defectivos do L RNA que apresentam extensas deleções internas e retém os terminais genômicos deste segmento. MAISS et al. (1991) compararam, por hibridação por "Nothem blot", o RNA de vírus provenientes de isolados brasileiros com de isolados búlgaros, obtendo uma seqüência quase que totalmente idêntica para 0 menor segmento de RNA (S RNA) entre os isolados dos dois países. A única diferença observada foi quanto a uma seqüência intergênica não-traduzida, que tem 81 nucleotídeos a mais no isolado búlgaro do que no brasileiro A seqüência do S RNA de um isolado brasileiro do VVCT foi obtida e comparada com a de outros isolados, revelando semelhança com o INSV ("impatiens necrotic spot virus") (PANG et al., 1993).

Assim, atualmente o RNA de muitas estirpes do VVCT de diferentes partes do mundo estão sendo sequenciadas e analisadas, levando a um maior conhecimento de suas características peculiares entre os vírus de planta.

\section{b) Composição Protęica}

Os primeiros estudos sobre a composição protéica do VVCT foram conduzidos por MOHAMED et al. (1973) e revelaram três proteínas de pesos molecular de $84 \mathrm{kD}, 50 \mathrm{kD}$ e 29 $\mathrm{kD}$, sendo que todas as três mostraram-se como sendo glicoproteínas. Ainda com base neste trabalho, concluíu-se que o vírus teria três camadas circundando o ácido nucléico central. 
Usando preparações de partículas purificadas e desintegradas, TAS et al. (1977) detectaram sete proteínas estruturais, sendo que quatro delas foram identificadas como glicoproteínas.

Em estudo posterior, MOHAMED et al. (1981) detectou a presença de quatro proteínas estruturais com pesos moleculares semelhantes aos valores obtidos por TAS et al. (1977).

Como mencionado anteriormente, está estabelecido que este vírus possui : uma proteína não-estrutural codificada pelo L RNA (331,5 kD); uma glicoproteína precursora das constituintes da capa protéica G1 e G2, de 127,4 kD e uma proteína não-estrutural (NSm) de 33,6 kD codificadas pelo segmento M RNA, no sentido viral complementar e viral, respectivamente; uma proteína estrutural (Ns) de $28,8 \mathrm{kD}$ que é provavelmente a transcritase viral e uma proteína nãoestrutural de 52,4 kD, codificadas pelo S RNA no sentido viral complementar e viral, respectivamente (HAAN et al., 1990, 1992; KORMELINK et al., 1992c).

A expressão e a localização da proteína NSm mostra que esta proteína localiza-se associada a agregados de nucleocapsídeos no citoplasma e em associação íntima com o plasmodesmata, fornecendo evidências de que a NSm é a proteína responsável pelo movimento virótico do VVCT, tomando parte da movimentação de célula a célula dos ribonucleocapsídeos não-envelopados (KORMELINK et al., 1994).

A organização das proteínas e a estratégia de leitura do material genético viral estão esquematizadas na figura 1. 


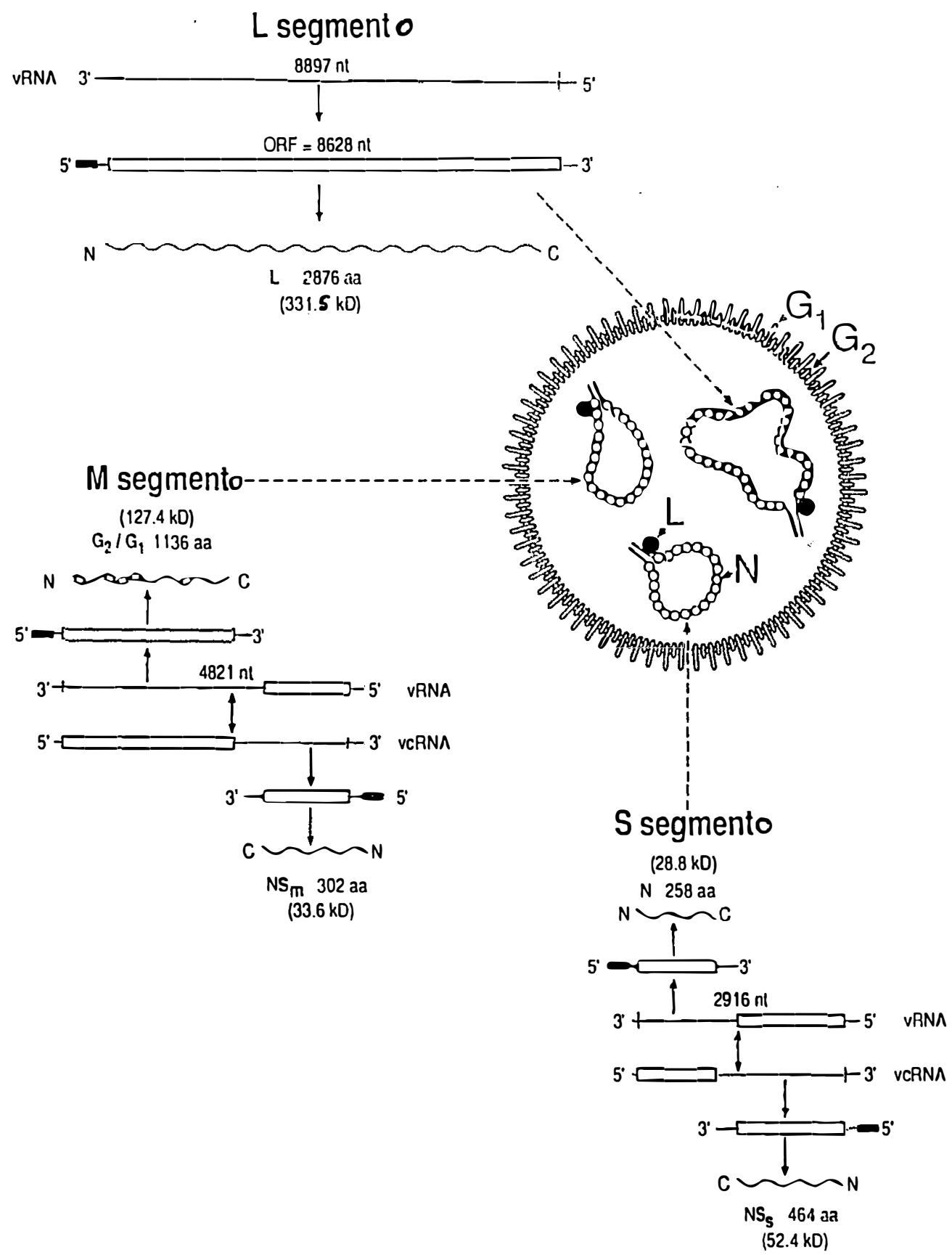

Figura 1 : Estrutura e estratégia de expressão gênica do VVCT, segundo RESENDE (1993). 


\subsubsection{Citopatologia e Efeitos da presença do VVCT sobre o hospedeiro}

BEST (1968) afirmou que os efeitos da infecção com o VVCT são, na realidade, devidos às alterações no metabolismo normal da planta do que propriamente ao acúmulo de núcleoproteína viral. Ocorre o acúmulo de inclusões citoplasmáticas nas células infectadas pelo vírus (KITAJIMA, 1965; FRANCKI \& GRIVELL, 1970). Outras inclusões citoplasmáticas tem forma de feixes longos, que interceptam os agregados de partículas completas e os viroplasmas. No entanto, estas estruturas não são muito comuns e a sua função exata ainda é desconhecida (FRANCKI \& HATTA, 1981).

Este vírus é capaz de invadir todos os órgãos e tecidos vegetativos das plantas hospedeiras sistêmicas, incluindo as células que estão sofrendo mitose (FRANCKI \& GRIVELL, 1970). O tecido anteridial de Tropaeolum majus L. foi observado por IE (1973) e, embora fossem detectadas partículas de VVCT no tecido endotelial, estas não foram encontradas nas células tapetais ou nos grãos de pólen. Houve apenas um trabalho mencionando a transmissão de VVCT por semente, mas em trabalho posterior esta situação não foi confirmada (FRANCKI \& HATTA, 1981). As plantas infectada por VVCT formam quantidade anormais de uma substância fluorescente e solúvel em água, que foi identificada com 6-metóxi, 7-hidróxi 1,2-benzopirona, também chamada escopoletina. (BEST, 1968).

Esta substância pode ser facilmente visualizada em folhas com lesões necróticas observadas sob luz ultravioleta. A presença da escopoletina manifesta-se como uma fluorescência azulada que localiza-se no tecido verde sadio imediatamente adjacente à lesão necrótica. Esta é a área foliar em que o vírus multiplica-se (BEST, 1968). Concluiu-se, através de observações desta fluorescência, que o virus passa das folhas inoculadas para as outras por meio dos feixes vasculares no interior da nervura principal e ao longo das nervuras laterais, até atingir as nervuras menores, só posteriormente é que o vírus atinge o mesófilo foliar.

ANDRAE (1952) mostrou a inibição do ácido indol-acético por sua oxidase é provocada pela escopoletina e, posteriormente FLEET (1961) afirma que esta substância é considerada como um antibiótico A escopoletina também está presente em plantas sadias, mas em menor quantidade. No entanto, observa-se que esta quantidade aumenta quando a planta entra em senescência. 
BEST (1968) sugere que o acúmulo da escopoletina deva-se ao desequilíbrio provocado na homeostase de algumas enzimas devido ao bloqueio provocado pela presença do vírus em uma via metabólica normal. 0 mesmo autor sugeriu que a produção e acúmulo da escopoletina pode ser devido a um número de reações normais envolvendo derivados de fenil propano as quais podem estar relacionadas com a biossíntese do ácido clorogênico, via ácido cafeico, outras reações associadas à biossíntese da tirosina e outras da biossíntese do ácido coniferil, que tem a escopoletina como produto final (BEST, 1968).

HORIBE (1990) mostrou que alterações no perfil eletroforético de ácidos nucléicos totais e proteinas solúveis totais estão associadas à interação vírus-cultivar, sendo que resistentes, tolerantes e susceptíveis tem perfis protéicos e de ácidos nucléicos diferentes, reforçando a idéia das alterações metabólicas provocadas pela presença do vírus.

\subsubsection{Estratégias de Controle}

BEST (1968) citou o uso de variedades resistentes, a redução na influência do insetovetor, a inoculação de estirpes menos virulentas e o parasitismo como métodos de controle do VVCT em sua revisão sobre este patógeno.

O insucesso do uso de variedades resistentes é provavelmente devido ao fato de a maioria dos genes de resistência encontrados serem de resistência vertical, ou seja, só conferem resistência a uma determinada estirpe do vírus.

Além disso, o controle do inseto-vetor também não tem sido muito bem sucedido, o que é agravado pelo fato do VVCT possuir um espectro muito amplo de hospedeiros sendo muitos deles espécies perenes, o que toma inviável a redução de reservatórios naturais, responsáveis pelo aumento do potencial de inóculo (FRANCKI \& HATTA, 1981).

O uso de estirpes mais suaves como proteção contra as mais virulentas não obteve resultados muito encorajadores (BEST, 1968).

FÁZIO et al. (1987) observaram que pulverizações com ácido acetil-salicílico e ácido poliacrílico são capazes de induzir resistência ao VVCT em plantas de fumo, através da síntese de um fator antiviral. Uma redução nos simtomas foi obtida com o uso do agente viricida ribavirina (virazole), além da eliminação de proteínas virais presentes no perfil eletroforético de proteínas solúveis totais em tomateiros comerciais altamente susceptíveis a este vírus (HORIBE, 1990). 
De acordo com GIELEN et al. (1991) para vírus de fita de RNA negativa, a resistência , mais eficiente quando obtida através da transformação do hospedeiro com a proteína do nucleocapsídeo virótico, sendo que a eficiência da adição de resistência às plantas transgênicas também foi alta. Portanto, os dois métodos parecem eficientes na redução de susceptibilidade de hospedeiros ao VVCT.

HAAN et al. (1992) realizaram estudo visando deseṇvolver um método de introdução de genes de resistência a vírus de fita de RNA negativa em plantas. Quanto à resistência, os resultados foram bons quando se introduziu no genoma do hospedeiro o cístron correspondente ao gene da nucleoproteína $\mathbf{N}$. A redução no número de lesões locais e um atraso no aparecimento dos sintomas foi obtido em plantas transgênicas de fumo (Nicotiana tabacum L.) que expressam o gene N de VVCT (KIM et al., 1992).

Genótipos de Capsicum sp. foram avaliados para a resistência a este vírus e a Phytophthora capsici, por BOITEUX et al. (1993), sendo que um deles mostrou resistência adequada a ambos os patógenos - PI 159236. Portanto, percebe-se que as pesquisas mais recente para controle do VVCT têm -se voltado preferencialmente para o uso de substâncias antivirais de amplo espectro de ação e uso de cultivares resistentes obtidos por engenharia genética

\subsection{Uso de Protoplastos em Virologia}

0 termo "protoplasto" ( protos = primeiro, plastos = formado) foi introduzido por Hanstein em 1880 para designar a matéria viva presente no interior das células, mas o significado geral deste termo citológico foi consideravelmente reduzido, pois atualmente usa-se o termo "protoplasto" apenas para ser referir ao resultado da remoção da parede celular .

A adequação ou não do termo é discutida por COCKING (1972). No presente trabalho o termo "protoplasto" será utilizado para designar célula isoladas das quais a parede celular foi removida inteiramente, como é usual.

0 isolamento de protoplastos a partir de tecidos vegetais intactos não tem um procedimento fixo e universal para sua realização, sendo altamente dependente do organismo e das condições em que se deseja eliminar a parede celular (DIXON, 1987). 
Para as células vegetais o procedimento mais utilizado, embora com variações e particularidades para cada espécie, tem sido o da degradação enzimática da parede celular, proposto por COCKING (1960).

0 métodos mecânicos de isolamento de protoplasto não são muito eficientes, pois o número de protoplastos viáveis obtidos é baixo, assim apenas a partir do método enzimático é que o uso de protoplastos e o seu estudo tomou-se mais intenso. As principais vantagens relacionadas ao uso do método enzimático são : (1) o maior número de protoplastos obtidos, (2) a menor alteração osmótica do citoplasma requerida e (3) redução no número de células danificadas (COCKING , 1972).

Nos primeiros experimentos envolvendo protoplastos, SCHENK \& HILDEBRANDT (1969) obtiveram protoplastos viáveis de dezenove plantas superiores utilizando celulases comerciais purificadas, ou seja, que sofreram extração com acetona acidificada, precipitação com etanol, filtração em gel e adsorsão em carvão vegetal. 0 fator limitante para a produção de protoplastos era a disponibilidade de enzimas comerciais adequadas.

Alguns fatores ambientais devem ser cuidadosamente monitorados durante o isolamento e todo o cultivo de protoplasto in vitro :

a)Condições osmóticas - a pressão exercida pela parede celular retirada tem que ser substituida pela pressão osmótica da mistura de isolamento e do meio de cultura para manter a homeostase celular (FOWKE \& CONSTABEL, 1985), sendo que para isto deve-se utilizar compostos químicos mais adequados à espécie com que se trabalha (PEBERDY, 1979).

Segundo GROSSET et al. (1990) protoplastos de fumo cultivados em meio sintético produzem e acumulam proteínas típicas de estresse celular, como aquelas sintetizadas apenas por células de fumo bem adaptadas a elevadas concentrações salinas: as osmotinas. $\mathbf{O}$ que mostra que mesmo com estabilizadores osmóticos os protoplastos se encontram em condição de estresse.

b)Enzimas - a maioria das enzimas líticas presentes nas misturas para obtenção de protoplastos, provém de fungos que crescem em materiais que compõem a parede celular. Estas enzimas são divididas em duas categorias:

b.1) pectinases - que dissolvem a lamela média e separam uma célula da outra e,

b.2) celulase e hemicelulases - que propriamente degradam a parede celular, liberando os protoplastos (FOWKE \& CONSTABEL, 1985). 
Segundo PEBERDY (1979) não se conhece exatamente quais são as enzimas envolvidas nas misturas líticas comerciais para a obtenção de protoplastos viáveis, sabe-se que $\alpha$-glucanase ( $\alpha$-1,3-glucanase), $\beta$-glucanase ( $\beta$-1,3- $\alpha$-1,6 glucanase) e algumas quitinases estão presentes.

Atualmente existem diversas enzimas comerciais adequadas à obtenção de protoplastos, uma lista das mais utilizadas é apresentada por ERIKSSON (1985). Portanto, isto não é mais fator limitante para o processo.

Tem sido observado que misturas enzimáticas altamente puras, com um só tipo de enzima presente, tem eficiência menor quando comparadas às que englobam diferentes tipos de enzimas (PEBERDY, 1979; FOWKE \& CONSTABEL, 1985). A capacidade hidrolítica de fungos nãoindustriais também é motivo de investigações para que seja aumentada a eficiência do processo de obtenção enzimática de protoplastos ( LEAL et al., 1994).

c) Material Vegetal - espera-se que o material do qual os protoplastos serão separados esteja em boas condições fisiológicas, livre do ataque de parasitas e pragas, além de estar preferencialmente livre de produtos químicos indesejáveis. Deve-se dar preferência às células jovens que possuem parede celular mais fina e atividade metabólica mais alta (COCKING, 1960). 0 órgão vegetal a ser utilizado depende do tipo de estudo futuro, sendo que o mais comum , a utilização de mesófilo foliar.

FOWKE \& CONSTABEL (1985) afirmam que altas concentrações de auxina e de aminoácidos, aliadas a baixas concentrações de açúcares, levam a uma maior eficiência na produção de protoplastos. DMITRIEVA et al.(1988) descobriram que altas concentrações de auxinas interferem na duplicação da cromatina de protoplastos de fumo. THEODOROPOULOS et al. (1990) afirmam que diferentes hormônios vegetais, reguladores de crescimento e glutamina não tiveram efeito como agentes aumentadores da sobrevivência de protoplastos, enquanto que extrato de coco provocou aumento significativo na sobrevivência do mesmo material.

d) Purificação dos protoplastos - este procedimento deve ser muito cuidadoso, pois a única separação entre a célula e o meio extemo : a membrana plasmática, se encontra em condição de estresse. Este passo pode ser realizado por centrifugação sob velocidade controlada e em condições osmóticas favoráveis à célula. 
Além destes fatores também deve-se atentar para a luz (não deve ser muito intensa e no caso de plantas mais sensíveis, recomenda-se um gradiente de luz para readaptar os protoplastos após o isolamento), concentração hidrogeniônica, temperatura de cultivo e pressão parcial de oxigênio no meio (PEBERDY, 1979), presença de substância que possam ter efeito inibitório ao crescimento e multiplicação dos protoplastos, como íons amônio (KNNO-OKA et al., 1993).

A viabilidade e a densidade de protoplastos são parâmetros interessantes de serem medidos após o isolamento das células e durante o seu cultivo. Existem diversos métodos para avaliação da viabilidade celular dos protoplastos, como por exemplo, os citados por KANAI \& EDWARDS (1973) que utiliza o corante azul de Evans e FERRARI et al. (1975) usando fenilsafranina. Métodos mais simples como com a utilização de azul de metileno; em que as células vivas, devido ao seu elevado poder redutor, tomam-se amarelas pela redução do corante no seu interior; e a observação direta da ciclose, movimento dos cloroplastos, também são utilizados (FOWKE \& CONSTABEL, 1985).

Como já foi frisado anteriormente, os protoplastos são muito importantes para uma grande quantidade de estudos biológicos e bioquímicos em geral, assim, podemos destacar alguns de seus usos :

a) Regeneração de plantas livres de pragas e patógenos - através de protoplastos enzimaticamente isolados e assepticamente cultivados in vitro até que regenerem um callus e, posteriormente, uma planta completa, pode-se obter mudas totalmente sadias de modo a não introduzir novos patógenos e parasitas no campo.

De uma enorme gama de trabalhos sobre este ponto, pode-se destacar os trabalhos de NAGATA \& TAKEBE (1970) que estudaram o tempo em que protoplastos isolados regeneram a parede celular e iniciam um processo de agrupamento celular, sendo que para isto eles requerem ácidos nucléicos e nucleoproteínas. ULRICH et al. (1980) relatou a diferenciação de células provenientes de protoplastos cultivados em raiz.

A obtenção de plantas completas a partir de protoplastos , um processo delicado e longo, mas que tem sido freqüentemente obtido, como o exemplo relatado por YOU-YING et al. (1985).

b) Fusão de materiais genéticos naturalmente incompatíveis - com a remoção da parede celular, a incompatibilidade entre as células, grandemente reduzida, o que fornece um instrumento de inestimável valor para os estudos e projetos de melhoramento genéticos (POWER et al., 1970). 
Existem muitos trabalhos a este respeito, mas relacioná-los todos fugiria ao objetivo desta revisão, que é apenas fornecer aspectos gerais da utilização de protoplastos enfatizando os estudos referentes a víns. Assim, os trabalhos referidos são apenas exemplos cronológicos de como se conseguiu fundir materiais geneticamente diferentes.

Para melhorar a porcentagem de fusão, WALLIN et al. (1974) utilizaram o polietileno glicol (PEG) e constataram que, realmente, esta substância se mostrou um agente fusogênico eficiente, embora não pudessem esclarecer exatamente o seu modo de ação. BRAR et al.(1979) afirmaram que no procedimento de fusão, as espécies vegetais a serem fundidas e órgãos de que os protoplastos são retirados, também são fatores importantes na eficiência de fusão.

ZIMMERMANN \& SCHEURICH (1981) usaram campo elétrico para aumentar a porcentagem de fusão, sendo que sua conclusão foi que a quebra dielétrica devido à proximidade das células leva a alterações na condutância, permeabilidade e, provavelmente, fluidez da membrana fazendo com que as células se fundam. BATES et al. (1983) construíram e comercializaram o modelo aperfeiçoado de fusão de protoplastos, dando início a uma intensa utilização destes procedimentos em laboratórios do mundo todo.

A eficiência global dos procedimentos de fusão foi progressivamente aumentada : LUCY (1984) mostrou a importância dos íons de cálcio, além de esclarecer as bases bioquímicas da fusão das membranas de protoplastos. TEMPELAAR \& JONES (1985) melhoraram o posicionamento dos eletrodos na câmara de fusão, de modo a elevar a freqüência de protoplastos fundidos.

HALL et al.(1992) sugeriram a radiação ultravioleta como pré-tratamento para células doadoras de material genético em experimentos de hibridação assimétrica de protoplastos vegetais.

c) Microcirurgia para isolamento de organelas - os protoplastos facilitam os estudos de componentes citoesqueléticos e de vesículas circundadas por membranas isolados da célula (FOWKE \& CONSTABEL, 1985).

$\mathbf{O}$ isolamento de núcleos de protoplastos vegetais para preparações nucleares de alta pureza, com baixas impurezas citoplasmáticas e sem agrupamentos dos mesmo, é altamente vantajoso para se obter o material estruturalmente íntegro (SAXEMA et al., 1985).

Ainda com a ajuda desta técnica de microcirurgia, GLUND \& ABEL (1989) estudaram a associação de sistemas vacuolares a retículos endoplasmáticos, num trabalho de grande importância para a fisiologia vegetal e para a citologia. 
Todas estas utilizações dos protoplastos mostram sua importância para a biologia em geral, mas na virologia, o uso de protoplastos tem um papel decisivo (COCKING, 1972; TAKEBE, 1975; SANDER \& MERTES, 1984; WOOD, 1987). O entendimento da infecção virótica das plantas superiores é altamente dependente do conhecimento do processo de infecção em uma célula individual, que é o constitumte básico de um corpo vegetal. Infelizmente até pouco tempo atrás não havia material vegetal adequado para o estudo da infecção a nível celular: materiais como plantas, órgãos e tecidos eram inadequados para este propósito, já que o número de células inicialmente infectadas pela inoculação é extremamente pequeno e o estágio de infecção está aleatoriamente espalhado por todo o material em cultivo.

Nos últimos quinze anos uma grande quantidade de informações sobre vários aspectos da infecção de vírus de planta foi obtida através do uso de protoplastos (SHAW, 1985), possibilitando inclusive a co-infecção de protoplastos de um mesmo hospedeiro com diferentes vírus e viróides ou satélites para que se verifique as interaçōes entre eles (MARCHOUX, 1988).

No entanto, o efeito da presença do víns em um sistema de cultivo de protoplastos nem sempre reflete o que ocorreria em um tecido íntegro, onde há influência muito maior do ambiente e de outras partes da planta.

SIDWELL \& HUFFMANN (1971) desenvolveram sistemas de teste passíveis de reprodução que utilizam-se de pequenas quantidades de substâncias químicas para avaliar a atividade de vírus e interferons. Sendo que afinnaram que os efeitos obtidos foram idênticos aos conseguidos em condições de campo.

OTSUKI et al. (1971) estudaram os efeitos do vírus do mosaico do fumo (TMV Tobamovirus) em tecidos foliares intactos e em protoplastos, ambos de cultivares que exibem resposta necrótica e sistêmica ao vírus.

0 crescimento do víns foi idêntico para os protoplastos e para os tecidos intactos, mas não houve morte celular dos protoplastos por necrose, o que os levou a concluir que o gene da planta que expressa resposta necrótica necessita que haja uma interação entre as células para que o dano provocado pelo vírus se manifeste na forma necrótica. 
Com trabalho semelhante ao anterior, COUTTS (1978) também observou que cultivares que normalmente apresentam resposta necrótica ao ataque de vírus, não tiveram esta característica em seus protoplastos. Sua conclusão foi que para a ocorrência da lesão necrótica o material infectivo precisa passar de uma célula adjacente à outra, de modo que a lesão se forme por perda sucessiva de água das células, sendo que os protoplastos isolados funcionam como uma barreira física para a perda de água, evitando assim a formação da lesão necrótica. As características do transporte de partículas virais de uma célula a outra e sua influência sobre a resistência ou susceptibilidade da planta hospedeira são discutidas por ATABEKOV \& DOROKHOV, 1984.

WELLINK et al. (1993) descobriram a presença de uma proteína codificada pelo vírus do mosaico do caupi (CPMV - Comovirus) que tem um papel essencial no transporte de partículas do vírus de uma célula à outra. Esta e outras proteinas semelhantes podem contribuir para o transporte de partículas viróticas mesmo na ausência de contato direto entre as células.

A expressão de genes clonados do vírus do mosaico do caupi foi menor em protoplastos do que em tecidos íntegros do seu principal hospedeiro (VOS et al., 1988).

AGRAWAL (1989) apresenta uma revisão completa sobre os processos bioquímicos envolvidos na replicação virótica em tecidos vegetais intactos e em protoplastos, mas não discute a questão da resposta necrótica em protoplastos.

Segundo os resultados de YOUNG et al.(1989) a expressão dos sintomas de infecção virótica podem ser melhorados com a adição de polietileno glicol (PEG) ao meio e com o uso de protoplastos de gramíneas. As razões para isto não são elucidadas pelo trabalho, embora alguma hipóteses sejam apresentadas. A ativação específica de alguns genes da planta somente em condições de protoplasto é aventada como uma possibilidade. Além do fato de muitas proteinas sinalizadoras localizam-se no apoplasto e associadas à parede celular, o que impediria ou reduziria a sua ação no caso de protoplastos (LOEBENSTEIN, 1972; BOWLES, 1990; ENYEDI et al., 1992; FARMER \& RYAN,1992).

GERA et al. (1990) notou que uma proteína específica considerada como inibidora da replicação de vírus (IRV), liberada pelos protoplastos de um cultivar de fumo supersensivel quando infectado pelo vírus do mosaico do fumo, o que mostra que mesmo sob a forma de protoplastos as células vegetais têm os genes de proteínas com atividade antiviral ativados na ocasião de sua colonização por vírus. 
Estruturas tubulares, supostamente envolvidas na transferência de vínus de uma célula a outra em tecido sadio, também são formadas em protoplastos, mesmo com a ausência da parede (LENT et al., 1991).

O trabalho de LARKIN et al. (1991) que mostra que um gene que confere resistência à planta integra não tem efeito algum quando presente em protoplastos. ISHIKAWA et al. (1991) que mostram que o vírus do mosaico da abobrinha (CCMV - Cucumovirus) que se replica em protoplastos não promove o acúmulo da sua fita negativa de RNA. Isto sugere que além dos sistemas vegetais de sinalização molecular, a própria replicação virótica é afetada em protoplastos.

WEILAND \& DREHER (1989) observaram que RNA de "turnip yellow mosaic virus" (TYMV - Tymovirus) inserido em protoplastos e tecidos íntegros de seus hospedeiros, teve menor multiplicação em protoplastos do que em tecidos completos. Mais marcadamente ainda, CHEN et al. (1990) obtiveram diferenças no próprio padrão de crescimento do vírus do mosaico do fumo (TMV - Tobamovirus) entre protoplastos e tecidos íntegros de mesófilo foliar, reforçando as observações anteriores.

\section{3 Substâncias Antivirais}

\subsubsection{Substâncias Antivirais e seu Uso}

Substâncias antivirais são aquelas que tem a capacidade de inibir total ou parcialmente a multiplicação de um vírus no tecido hospedeiro. As substância antivirais podem ser induzidas pela presença do patógeno e sintetizadas pelo próprio hospedeiro ou podem ser artificialmente produzidas de maneira exógena.

Em plantas íntegras a resistência contra vírus pode ser atribuída à vários mecanismos : (a) entrada do vírus é dificultada, por exemplo por uma epiderme mais espessa que dificulta a ação do inseto-vetor, (b) o movimento do vírus de uma célula para outra é inibido, (c) o movimento do vírus de uma célula a outra é impedido por um processo de localização - necrose, (d) inibição da disseminação do vírus nos feixes vasculares, (e) a replicação viral é inibida a nível celular. Exceto pelo primeiro aspecto, todas as outras causas podem ser encontradas em experimentos in vitro com o sistema de cultivo de protoplastos (SANDER \& MERTES, 1984). 
Assim, substâncias inibidoras da replicação de vírus (IRV) e substâncias antivirais tem ação semelhante em protoplastos e tecidos íntegros.

SELA (1981) revisou a inibição da multiplicação de vírus a nível celular pela produção de substâncias antivirais, que são produzidas em células infectadas e podem ser translocadas para células vizinhas não infectadas que tomam-se resistentes. Aparentemente estas substâncias agem sobre a replicação do material genético viral.

O uso da actinomicina D como agente antiviral foi revisto por SANDER \& MERTES (1984), sendo que este produto age como inibidor da RNA polimerase - dependente de DNA, impedindo, portanto, a síntese protéica. A especificidade deste produto não é observada e a inibição satisfatória sem prejuízos à célula hospedeira só ocorre quando de sua adição durante ou logo após a inoculação.

Segundo FÁZIO et al.(1987) os ácidos acetil-salicílico e poliacrílico foram capazes de evitar a infecção sistêmica do TMV (vírus do mosaico do fumo - Tobamovirus) e do VVCT quando aplicados anteriormente à inoculação

Atualmente, as pesquisas voltam-se para substâncias antivirais alternativas como própolis (AMOROS et al., 1992), hipoclorito e dicloroisocianurato de sódio (TSIQUAYE \& BARNARD, 1993) e até substâncias detergentes (MARIS, 1986).

O uso da cicloxolona de sódio (CCX) também tem sido testado para diversos vírus : vírus da estomatite vesicular (VSV) (DARGAN et al., 1992a), Adenovirus do tipo 5, Reovirus do tipo 3, Poliovirus do tipo 1, dois Bunyavirus e o vírus da floresta Semliki (SFV) (DARGAN et al., 1992b). Estes autores mostram que o efeito da substância antiviral é função de : (a) redução na quantidade de partículas de vírus produzidas, (b) perda de infectividade relativa e (c) efeito viricida da droga.

BAUER et al. (1993) mostram que a reversão quase completa da infecção de ervilha com o víns do mosaico da alfafa (AMV - Alfamovirus) foi conseguida com a aplicação de 1-( $\alpha$ carboxialquil)-4,5-dimetil 1 imidazol-3 óxido.

\subsubsection{Ribavirina ou Virazole ou 1- $\beta$-D-ribofuranosil-1,2,4- triazole-3-carboxamida}

A ribavirina ( ou virazole ou 1- $\beta$-D-ribofuranosil - 1,2,4-triazole-3-carboxamida) é um antimetabólito, ou seja, uma guanosina análoga que tem o anel das purinas aberto, e portanto, não é funcional quando incorporada ao ácido nucléico, funcionando como inibidor de multiplicação de vírus de DNA e de RNA. 
Esta inibição em sistemas de células animais realiza-se da seguinte maneira : a ribavirina é fosforilada nas células e inibe competitivamente a inosina monofosfato desidrogenase (IMP), interferindo na biossíntese de nucleotídeos guanosina e adenina. (STREETER et al., 1973). Devido a esta redução no "pool" de nucleotídeos, acredita-se que a multiplicação do víns seja inibida.

No entanto, esta explicação não seria suficiente para casos em que se observa uma especifícidade desta substância, como os relatados por ERIKSSON et al., (1977) e GOSWAMI et al. (1979).

BYHAN et al. (1978) estudaram o efeito da ribavirina sobre a síntese do RNA do hospedeiro e do vírus em Nicotiana tabacum L. infectada com o vírus do mosaico do fumo (TMV-Tobamovirus). Neste trabalho, a ribavirina inibiu seletivamente a síntese de RNA viral, sem afetar significativamente a síntese do RNA do hospedeiro.

A vantagem do uso de protoplastos para a avaliação do efeito de ribavirina é que facilita o isolamento de grande quantidade de protoplastos em condições ambientais sempre uniformes e com menos trabalho do que para a manutenção de plantas em casa de vegetação (SANDERS \& MERTES, 1984). Também foi observado na mesma revisão que existem poucos estudos com ribavirina, pois este composto é tóxico e teratogênico ao homem.

Segundo DAWSON \& LOZOYA-SALDANA (1984) a cinética da inibição da multiplicação do TMV (vírus do mosaico do fumo - Tobamovirus) por tratamento com ribavirina envolve tanto a inibição da síntese protéica quanto da síntese de RNA, sendo que o tratamento só se mostrou eficiente quando realizado pouco tempo após a inoculação. Estes autores também sugerem que o mecanismo de inibição da replicação do TMV em plantas ocorre de uma maneira diferente do anteriormente proposto (STREETER et al., 1973) para células animais. Segundo eles, a inibição dá-se em um passo ainda anterior ao início da biossíntese do RNA viral.

FÁZIO et al.(1980a e b) mostraram que o uso de ribavirina é capaz de prevenir a infecção sistêmica de tomateiros pelo VVCT quando aplicada imediatamente após a inoculação e também é capaz de controlar e atrasar esta infecção quando aplicada anteriormente à inoculação com o vírus. Em seus experimentos, verificaram também que o antiviral inibiu a multiplicação do VVCT e retardou a sua translocação no interior das plantas.

O efeito da ribavirina na eliminação do vírus do mosaico da petúnia em cultura de tecidos, foi eficaz promovendo culturas livres deste patógeno, mas foi necessário o uso da ribavirina durante todo o cultivo (AMINUDDIN \& SINGH, 1985). 
Concentrações de ribavirina variando desde $100 \mu \mathrm{g}$ a $200 \mu \mathrm{g}$ por ovo, foram testadas para a eliminação de vírus em ovos embrionados. Observou-se que após 24 a 48 horas do tratamento os embriões sofreram hemorragia e morte e que $o$ antiviral não foi capaz de retardar a multiplicação dos vírus (HUSSAIN \& MUHAMMAD, 1987).

A inibição de Phlebovirus por ribavinina foi observada por SIDWELL et al. (1988). Os Phlebovirus possuem semelhança moleculares, morfológicas e citopatológicas com os Bunyavirus, indicando que o modo de ação é provavelmente igual para ambos.

Células de rim felino infectadas com o víns da periotonite felina infecciosa (FIPV) foram tratadas com ribavirina, sendo que observou-se que a inibição ocorreu de forma dose-dependente e a dose mínima causadora de inibição em células sadia foi $17 \mu \mathrm{g} / \mathrm{mL}$ enquanto que a dose inibitória para o FIPV foi de 2,5 $\mu \mathrm{g} / \mathrm{mL}$ (WEISS \& DOSTROM-RAM, 1989).

No trabalho de LOI et al. (1991) o uso desta substância na concentração de 5 a $15 \mathrm{mg} /$ $\mathrm{L}$ de meio de cultura e de 10 a $40 \mathrm{mg} / \mathrm{L}$ de meio de cultura foi suficiente para a obtenção de callus e cultura de gemas livres de "cymbidium mosaic potexvirus" e "odontoglossum ringspot tobamovirus" para Dendrobium sp.. Semelhantemente, RAJ et al. (1991) relataram a eliminação de Tombusvirus de culturas in vitro de beringela com concentrações de ribavirina entre 100 e 150 mg / L de meio de cultura.

A combinação de ribavirina e 7-tia-8-oxoguanosina (TOGuo) contra o vírus Punta Toro em células animais mostrou um efeito sinérgico entre os dois antivirais, sendo que o TOGuo aumentou o índice terapêutico da ribavirina através de um decréscimo em sua toxicidade e um aumento na sua atividade antiviral (SMEE et al. , 1991).

A eficiência deste agente antiviral em culturas de células de Cymbidium sp. dependeu de três fatores : (a) isolamento acurado do tecido novo, (b) concentração de ribavirina e (c) freqüência de transplante para meio fresco, além disso as aplicações tiveram que ser repetidas por várias sub-culturas sucessivas para que o "odontoglossum ringspot tobamovirus" (ORV) fosse completamente erradicado (TOUSSAINT et al., 1993).

Apesar de sua eficiência contra grande número de vírus, WEISS et al. (1993) atentam para os efeitos toxicológicos da ribavirina em gatos. Dentre os efeitos observados podemos citar :

- 22 a $44 \mathrm{mg}$ de ribavinina / $\mathrm{kg}$ de peso vivo foi suficiente para causar anorexia e perda de peso,

- um terço dos animais usados no experimento sofreu diarréia e/ou torpor nas mucosas intestinais, 
- uma quantidade significativa dos gatos teve trombocitopemia ( redução nas plaquetas),

- todos os animais sofreram uma diminuição significativa nos leucócitos e redução no número de leucócitos circulantes e

- alta freqüência de hipoplasia megacariocítica.

A combinação de ribavinina com interferon de rato (IFN) teve efeito aditivo na inibição do vírus da floresta Semliki (SFV) em cultivo de células $\mathbf{L}$ em monocamadas, sendo que não houve multiplicação significativa do vírus (HARMSEN et al., 1994).

O uso de substâncias antivirais não esta muito difundido, especialmente para sistemas vegetais, onde o conhecimento e os estudos sobre isto ainda são muito deficientes. No entanto, o fato destas substâncias agirem indiscriminadamente sobre a maioria dos virus é uma indicação de que o seu uso pode vir a ser um instrumento valioso para o combate de doenças virais em plantas.

\section{4 Cinética de Crescimento de Cultivos de Células em Suspensão}

Freqüentemente os estudos de cinética de cultivos em suspensão envolvem células integras, quer sejam célula vegetais, animais, bacteriana ou de fungos filamentosos e leveduras. No entanto, de uma forma geral, as leis físicas e químicas que govemam estes processos são as mesmas para o cultivo de protoplastos em suspensão, de modo que tudo que referir-se às células intactas nesta revisão pode ser aplicado ao cultivo de protoplastos em um sistema semelhante.

Quando tratamos de crescimento de células podemos considerar o crescimento individual de cada uma ou o aumento da população, embora esteja claro que o segundo é fumção do primeiro. Essencialmente quando nos referirmos aos cultivos de células em suspensão estaremos falando sobre o crescimento de uma população e não apenas de um indivíduo (MANDELSTAM et al., 1982).

O tempo que um número de organismos em cultura leva para dobrar o seu número nos fomece uma idéia de sua velocidade de multiplicação. Assim, GILISSEN et al. (1983) afirmam que o estado fisiológico de um cultivo está refletido em sua velocidade de crescimento, considerando-se a manutenção de condições ambientais ótimas para o seu desenvolvimento. 
Em um ambiente adequado, populações de células tendem a aumentar exponencialmente com a passagem do tempo. Portanto, é adequado considerar com "ideal" ou "normal" o estado de crescimento exponencial, sendo que outras condições ocorreriam apenas sob circunstâncias excepcionais (MANDELSTAM et al., 1982).

As curvas de crescimento são "plots" do crescimento de uma população, medido direta ou indiretamente, versus o tempo. 0 crescimento da população pode ser medido diretamente através de contagens do número de indivíduos ou através de outros parâmetros como a densidade óptica de uma suspensão de células (PIRT, 1975, NOORDAM, 1982), a massa, o conteúdo de nitrogênio, etc. As curvas características de células em suspensão são compostas por quatro fases :

- Fase lag ou estacionária = fase em que a população de células ainda está se adaptando às condições de cultivo e não atingiu a velocidade máxima de crescimento. Nesta fase não há inibição de crescimento por falta de substrato nem por acúmulo de metabólitos tóxicos.

- Fase log ou exponencial = fase em que o crescimento da população é máximo e não existem restrições ao crescimento. A velocidade de multiplicação das células é muito maior do que a taxa de mortalidade.

- Fase de desaceleração $=$ neste estágio as restrições ao crescimento se manifestam, fazendo com que se igualem a velocidade de multiplicação e de morte das células em cultivo. Esta fase marca o fim do crescimento exponencial de um cultivo e é propriamente uma fase curta por ser de transição.

- Fase terminal ou final = fase em que ocorre a exaustão dos nutrientes presentes no meio, fazendo com que as células cresçam muito mais lentamente. Se a velocidade de mortalidade das células for maior do que a sua multiplicação, o sistema entra na fase do declínio, mas se estas apenas se igualarem a fase estacionária se manterá (MANDELSTAN et al., 1982).

Existem modelos matemáticos que descrevem perfeitamente o comportamento de células em cultivo durante o curso do tempo (SEGEL, 1984). Segundo BARACHO (1985) todos os processos biológicos podem ser expressos através de fórmulas ou equações, tomando a biologia uma ciência precisa. 
O cultivo de células em suspensão é adequado ao modelo de um cultivo em batelada alimentada, ou seja, um sistema de cultura fechado que contém uma quantidade inicial de nutriente que posteriormente pode ser aumentada sem retirada de biomassa ou produto, contém também uma quantidade inicial de inóculo. Este tipo de cultivo passa pelas fases anteriormente mencionadas (STANBURY \& WHITAKER, 1986).

A fase exponencial pode ser descrita matematicamente da seguinte forma :

$$
\mathrm{dx} / \mathrm{dt}=\mu \mathrm{x}
$$

onde : $\mathbf{x}=$ concentração de células presente no cultivo

$t=$ tempo

$\mu=$ velocidade específica de crescimento (dada na mesma unidade do tempo, elevada a -1)

Se integrarmos a equação (1) teremos :

$$
x_{t}=x_{0} \mathrm{e}^{\mu t}
$$

onde : $x_{0}=$ concentração inicial de células no cultivo quando $t=0$

$x_{t}=a$ concentração de células após o intervalo de tempo $t$

$\mathrm{e}=$ base de logaritmos naturais (neperianos)

Aplicando logaritmos naturais na equação (2) obteremos :

$$
\ln \mathrm{x}_{\mathrm{t}}=\ln \mathrm{x}_{0}+\mu_{\mathrm{t}}
$$

Assim, um "plot" do logaritmo natural da concentração de células pelo tempo, dará origem a uma linha reta em que a inclinação será igual a $\mu$. A equação (2) prevê que o crescimento continuará indefinidamente, no entanto, o crescimento provoca o consumo de nutrientes e a excreção de metabólitos celulares : eventos que influenciam o crescimento do organismo. Assim, após um certo tempo a velocidade de crescimento da cultura diminui até que o crescimento cesse. A cessação do crescimento pode ser devida à deplecção de nutrientes essenciais do meio (limitaçōes de substrato), ao acúmulo de produtos autotóxicos do próprio organismo no meio (limitação por toxina) ou por uma combinação de ambos (STANBURY \& WHITAKER, 1986).

YOSHIDA et al. (1973) introduriram um novo termo para descrever culturas em batelada que são contínua ou seqüencialmente alimentadas com meio sem a remoção de fluido da cultura : batelada alimentada ("fed-batch culture").

Sob estas condições o volume da cultura aumenta com o tempo e suas características de cinética de crescimento foram resumidas e discutidas por PIRT \& KUROWSKI (1970); PIRT (1975) e STANFORD \& WHITAKER (1986) . 
Consideremos uma cultura em batelada na qual o crescimento está limitado pela concentração de um dos substratos; a concentração celular em qualquer ponto no tempo pode ser descrita por :

$$
x_{t}=x_{0}+Y\left(S_{R}-s\right)
$$

onde : $x_{t}=$ concentração de células após o tempot

$x_{0}=$ concentração inicial de células no tempo $t=0$

$\mathrm{Y}=$ fator de produtividade ( constante sem dimensão)

$\mathrm{S}_{\mathrm{R}}=$ concentração inicial de substrato

$s=$ concentração residual de substrato

A concentração final de células produzidas quando $s=0$ pode ser descrita como $x_{\max } e$, uma vez que $\mathrm{x}_{0}$ é muito pequeno quando comparado a $\mathrm{x}_{\max }$ teremos :

$$
\mathrm{x}_{\max }=\mathrm{YS}_{\mathrm{R}}
$$

Se, a um tempo em que $x=x_{\max }$ alimenta-se com meio fresco o cultivo de modo que a taxa de diluição é menor do que $\mu_{\max }$, virtualmente todo o substrato será consumido com a mesma velocidade em que ele entra na cultura, assim :

$$
\mathrm{FS}_{\mathrm{R}}=\mu \mathrm{X} / \mathrm{Y}
$$

onde : $F=$ velocidade de fluxo da alimentação do meio

$\mathrm{X}=$ total de células presentes na cultura, que é descrito por $\mathrm{X}=\mathrm{xV}$, sendo $\mathrm{V}$ o volume do recipiente que contém a cultura no tempo $t$.

A partir da equação (6), pode-se concluir que a entrada de substrato é igualada pelo consumo de substrato pelas células. Assim, $(\mathrm{ds} / \mathrm{dt})=0$. Embora a quantidade total de células na cultura $(X)$ aumente com o tempo, a concentração de células $(x)$ permanece virtualmente constante, ou seja,$(\mathrm{dx} / \mathrm{dt})=0 \mathrm{e}$, portanto, $\mu=\mathrm{D}$ (taxa de diluição).

Esta situação é chamada de quasi-homeostase. À medida que o tempo passa, a taxa de diluição diminui à proporção que o volume aumenta e $\mathrm{D}$ será dado pela equação :

$$
D=F /\left(V_{0}+F_{t}\right)
$$

onde : $V_{0}=$ volume original do cultivo.

Assim, de acordo com a cinética de Monod, o substrato residual deve diminuir a medida que $D$ diminui, resultando em um aumento na concentração celular. No entanto, para a maior variação de $\mu$ em que as culturas de batelada alimentada operam, $S_{R}$ será muito maior do que $K$, de modo que para todos os propósitos práticos, as mudanças na concentração do substrato 
residual serão extremamente pequenas e podem ser consideradas como iguais a zero. Assim, uma vez que $D$ é menor do que $\mu_{\max }$ e $\mathrm{K}$ é muito menor do que $S_{R}$, um estado de quasi-homeostase é atingido. $\mathbf{O}$ estado de quasi-homeostase é diferente de um estado de homeostase porque no primeiro o valor de $\mu$ não é constante e decresce com o tempo nas culturas em batelada alimentada.

Segundo STANBURY \& WHITAKER (1986) a principal vantagem do sistema de cultivo em batelada alimentada é que a concentração residual do substrato é mantida baixa, de modo que a remoção de efeitos repressivos e a manutenção das condições ótimas da cultura são facilmente realizáveis. Este tipo de cultivo também evita os efeitos tóxicos de componentes do meio.

Existem vários fatores que afetam o crescimento de células em cultura de batelada alimentada, entre eles destacamos :

- afinidade do organismo pela fonte de Carbono, Nitrogênio e Fósforo, entre outros nutrientes essenciais,

- temperatura do cultivo,

- pressão osmótica / concentração de sais,

$-\mathrm{pHe}$

- condições de aeração (MANDELSTAM et al., 1982).

Assim, uma vez que estas variáveis sejam mantidas em seu ponto ótimo para um dado sistema, o crescimento celular será o máximo e o único fator com influência será a condição fisiológica das células em cultivo.

As curvas de crescimento são processos complexos na Natureza, mas podem ser expressas matematicamente uma vez que leve-se em consideração as considerações propostas por SEGEL (1984) : (1) encontrar o estado de quasi-homeostase, (2) examinar a sua estabilidade, (3) fazer conjecturas sobre o seu comportamento qualitativo e (4) comparar as conjecturas com simulações realizadas na prática.

Existem inúmeros métodos de avaliar-se o crescimento de cultivos de células em suspensão, como :

- Contagem direta das células ou medida do seu volume,

- Peso fresco ou peso seco da biomassa produrida,

- Quantificação das proteínas celulares e

- Medidas de densidade óptica de amostras do meio. 
No entanto, este métodos apresentam muitas desvantagens, listadas por GILISSEN et al. (1983) :

- Presença de agregados de células na suspensão,

- Aderência das células ao vidro do recipiente que as contém,

- Tempo despendido com estes métodos, uma vez que requerem grande período de tempo disponivel para sua realização,

- Destruição das células presentes no cultivo e

- Perturbação do crescimento pela retirada de alíquotas para serem avaliadas.

Assim, este autores propõem altemativamente, um método de avaliação de crescimento de cultivos de células em suspensão que baseia-se na medição indireta do volume de células presentes através de uma reta de calibração. Os autores afirmam que este método é preciso, prático, rápido e não-destrutivo.

EVEREAT et al. (1989) usaram a cinética de expressão de produtos da fase "eclipse" da infecção de células HeLa com Poliovirus para avaliar a evolução da infecção e, conseqüentemente o estado infeccioso do cultivo.

A cinética da replicação do virus da febre hemorrágica da Criméia-Congo (CCHF) foi estudada por GONZALEZ et al. (1991) em carrapatos observando-se que quanto maior a quantidade de material viral presente nos carrapatos o estado físiológico geral das células foi pior.

Usando plantas integras, TAVANTZIS (1991) observou que o estágio de desenvolvimento da planta influencia o transporte de vínus no seu interior, assim deve-se observar o estágio de desenvolvimento na obtenção de protoplastos para cultivo em suspensão, de modo que o seu comportamento com relação à presença do vírus seja uniforme.

LU et al. (1992) conseguiram uma alta correlação $(\tau=0,957)$ entre o número de células infectadas com o virus HIV-1 ("Human Immunodeficiency Virus type 1") em uma amostra de sangue humano e o tempo em que esta amostra produz $1 \mathrm{ng}$ da proteína viral p24gag por $\mathrm{mL}$ de meio. $\mathbf{O}$ método desenvolvido por estes pesquisadores proporciona uma avaliação da prognose de indivíduos infectados com HIV-1.

A cinética de associação de um inibidor da transcritase reversa do HIV-1 mostra que o modelo mais adequado para esta condição é o equilíbrio dinâmico de Briggs-Haldane, que não pressupõe um equilibrio rápido entre a enzima e o seu substrato (ALTHAUS et al., 1994). 
SAKAGUCHI et al.(1993) tentaram correlacionar o nível de proteína prion (PrP) com a infectividade na doença de Creutzfeld-Jakob, mas observaram que apenas em alguns órgãos o aumento do acúmulo de PrP correspondeu a um aumento no nível de infectividade.

Tentando relacionar a produção de vírus em células animais com a expressão do epítope, OBI \& McCULLOUGH (1993) observaram que isto é viável para o "rinderpest virus", mas que os resultados não representaram fielmente o estado físiológico do cultivo.

A maioria dos estudos sobre cinética de crescimento de cultivos de células em suspensão in vitro envolve célula animais, sendo que estas investigações são raramente feitas em cultivos vegetais. Mas mesmo nestes casos, percebe-se que, parâmetro diretos como o número ou volume de células viáveis presentes e parâmetros indiretos como a velocidade máxima de crescimento ou a velocidade relativa de crescimento para um dado tempo, refletem bem as condições fisiológicas do cultivo.

\subsection{Alterações Protéicas devido a Patógenos}

\subsubsection{Considerações Gerais}

O contato das plantas com o ambiente é muito grande, uma vez que são sedentárias, portanto elas tem que possuir respostas rápidas aos estímulos externos para que possam sobreviver. Assim, quando em presença de um agente patogênico as plantas tem que contar com vias biossintéticas e metabólicas alternativas. 0 metabolismo das proteínas tem um papel essencial na proteção das plantas contra as situações de estresse biótico e abiótico.

As variações eletroforéticas de enzimas são muito úteis como instrumento de pesquisa por serem uma marca natural facilmente detectável e por serem o produto direto da atividade do gene, possibilitando uma análise da ação gênica na presposta a um processo de infecção (SHAW, 1965).

As proteínas envolvidas na resistência induzida e na localização (resposta hipersensível) aos vírus, bem como o seu papel nestas ocasiões e suas vias metabólicas de biossíntese, foram revistas por LOEBENSTEIN (1972). Neste trabalho é mencionado também o acúmulo de 
escopoletina, na infecção por determinados vírus, embora o seu papel na infecção não seja discutido.

A função das moléculas-sinalizadoras na indução de determinadas enzimas, alterando a expressão de determinadas vias metabólicas, foi discutida por LAMB et al. (1989).

As proteínas relacionadas à defesa de plantas, com enfoque especial para a defesa em caso de estresse abiótico, estão revistas quanto à sua ativação, classificação quanto ao modo de ação, biossíntese e função na presença de um patógeno, em trabalho publicado por BOWLES (1990).

As alterações causadas por patógenos podem ser visualizadas in situ através da impressão de proteínas foliares em membranas de nitrocelulose, como o que foi feito por HSU \& LAWSON (1991) para deteç̧ão do VVCT em folhas de Impatiens sp. 0 emprego desta técnica para observação da atividades de isoenzimas tem como vantagem a análise do que está ocorrendo na própria folha, sem que a sua estrutura seja prejudicada.

Os genes vegetais envolvidos na resistência aos vírus estão apresentados por DUMAS et al. (1990). A correlação entre a resistência da planta ao vírus e a produção de proteínas relacionadas à patogênese, mostra a importância do fator genético (YALPANI et al., 1993).

ENYEDI et al. (1992) e FARMER \& RYAN (1992) discutem as funções e os tipos de moléculas-sinalizadoras que têm a capacidade de induzir a síntese de proteínas relacionadas à patogênese e outras proteínas também associadas à presença de patógenos mas de menor peso molecular - fitoalexinas.

CUTT \& KLESSIG (1992) realizaram uma revisão sobre as proteína relacionadas à patogênese. Enquanto que as suas características foram confirmadas em observações feitas com diversos hospedeiros (SEHGAL, 1992; YOSHIKAWA et al., 1992).

O estudo de proteínas de estresse ou relacionadas à patogênese freqüentemente são feitos utilizando-se tecidos íntegros ao invés de protoplastos e isto possivelmente é devido ao papel essencial do apoplasto nas estratégias de defesa da planta, (BOWLES, 1990) e também devido à associação de moléculas sinalizadoras e proteínas de defesa à parede celular (LOEBENSTEIN, 1972; WAGIH \& COUTTS, 1981).

Além disso, protoplastos vegetais em condições ideais de cultivo em suspensão e sem contato com patógenos, sintetizam e acumulam proteínas associadas à patogênese. Segundo GROSSET et al. (1990), isto pode estar relacionado ao processo de obtenção dos protoplastos, uma vez que fragmentos da parede celular tem a capacidade de induzir algumas proteínas 
relacionadas à patogênese (LAMB et al., 1989) ou à presença de hormônios vegetais como 2,4 D (ácido 2,4 diclorofenolacético) e ANA (ácido naftaleno acético), que reduzem a resistência de protoplastos às infecções virais (BELL, 1981).

Existem diversos trabalhos atuais que relatam a indução de quitinase em plantas devido à presença de patógenos, uma vez que estas enzimas tem alta capacidade hidrolítica (METRAUX et al., 1990; INBAR \& CHET, 1991; LINDEGREN et al., 1991). O mesmo ocorre com outras hidrolases como xilanase (LOTAN \& FLUHR, 1990), $\beta$-1,3-endo e exoglucanase (SOCK et al., 1990) e ribonucleases (SHARMA \& CHAWLA, 1989).

No entanto, existem semelhanças entre condições de estresse abiótico e estresse provocado por patógenos, pois muitas proteínas relacionadas à patogênese são comuns ou tem características semelhantes às encontradas sob estresse ambiental (BOL et al., 1993; YALPANI et al., 1994).

\subsubsection{Peroxidases}

Há muito tempo é conhecido que a presença de patógenos em um corpo vegetal é responsável por alterações nas quantidades e na atividade de peroxidases. Alterações semelhantes são observadas em condições de estresses abiớticos, uma vez que possam estar relacionadas com sua indução por etileno ou ácido acetil-salicílico (LOEBENSTEIN, 1972; COUTTS, 1978; BELL, 1981).

A peroxidase (E.C. 1.11.1.7.) é uma enzima constitutiva responsável pela catálise de um grande número de reações na planta. São responsáveis pela oxidação de muitos compostos fenólicos e outros tipos. As principais funções das isoformas desta enzima nos processos de estresse são :

- Biossíntese de lignina e suberina,

-Oxidação de compostos aromáticos produzidos pela via HMP,

-Oxidação de NADH e

-Eliminação do peróxido de hidrogênio formado por outras reações (LOEBENSTEIN, 1972; BOWLES, 1990).

Embora não conheça-se exatamente o seu papel, observa-se uma associação entre as peroxidases e a resposta de hipersenbilidade das plantas aos vírus, sendo que observa-se um 
acúmulo desta enzima nos tecidos verdes imediatamente adjacentes ao tecido necrosado (LOEBENSTEIN, 1972; BELL, 1981; BOWLES, 1990).

A combinação entre as peroxidases, haletos e peróxido de hidrogênio foi apresentada por BELDING \& KLEBANOFF (1971) como um sistema viricida eficiente e capaz de contribuir para a defesa do organismo contra estes fitopatógenos. 0 sistema peroxidase-peróxido de hidrogênio também mostrou efeito antiviral significativo, porém menor do que com o haleto presente.

A detecção destas enzimas pode ser feita por métodos quantitativos e qualitativos, além dos métodos histoquímicos que avaliam a atividade da peroxidase in vivo. Alguns destes métodos, bem como avaliações quanto a sua eficiência encontram-se em LUSSO (1989).

Comparando o estresse provocado por vírus com outros estresse não-biológicos, WAGIH \& COUTTS (1981), concluíram que alterações na condição da água em certos locais da célula, quer sejam causadas por patógenos quer não, levam a estresses microambientais que desencadeiam a síntese ou degradação das proteínas. Sendo que a peroxidase sofre alterações quantitativas e qualitativas em ambos os casos (WAGIH \& COUTTS, 1982 b e c; WAGIH \& COUTTS, 1982a).

WAGIH et al. (1983) observaram que ocorriam alterações no metabolismo protéico tanto devido ao ataque por patógenos, quanto devido ao estresse osmótico e afimaram que as reações ocorridas são universais e qualquer associação com a resistência induzida nas plantas foi acidental. No entanto, o aumento na atividade das peroxidases causado pelo estresse hídrico não foi tão intenso quanto o causado pela presença de vírus em tecido de caupi e de cucurbitáceas. Assim, o aumento na atividade das peroxidase foi maior para lesões necróticas provocadas pelo vírus, e em ordem decrescente pelo estresse osmótico, pelo excesso de água e pela abrasão mecânica (WAGIH \& COUTTS ,1982b).

Além disso, pelo padrão de isoenzimas analisado, observou-se que o perfil de isoperoxidases foi diferente para tecido plasmolisado por estresse osmótico do tecido com lesões necróticas provocadas por vírus. De um modo global, as células do tecido infectado passaram de um estado redutor para um estado oxidativo (WAGIH \& COUTTS, 1982c).

Portanto, a associação das peroxidases com processos patogênicos em células vegetais está perfeitamente estabelecida (CLARE et al., 1966; LUSSO, 1989; SHERIF et al., 1989; COUTTS \& WAGIH, 1982a e b), embora não se saibas se representam uma resposta específica ao processo de infecção (BRUCE \& WEST, 1989; REIMERS et al., 1992) ou não-specífica 
(SEEVERS et al., 1971; BIREKA et al., 1975; CZECH-KOSLOWSKA \& KRZYWANSKI, 1984; LAGRIMINI \& ROTHSTEIN, 1987; MALOLEPSZA \& URBANEK, 1994).

\subsubsection{Shiquimato Desidrogenase}

Esta é uma enzima-chave na biossíntese dos aminoácidos aromáticos, pois catalisa a redução do ácido deidroshiquímico, usando trifosfopirimidina como coenzima, a ácido shiquímco, que é o precursor da fenilalanima e tirosina (BALINSKY \& DAVIES, 1961a, b e c).

Entre as características da shiquimato desidrogenase (E.C. 1.1.1.25) podemos citar :

- São específicas para trifosfonucleotídeos

- pH ótimo situa-se ao redor de 10,00

- Não requer nenhum íon multivalente para sua ativação

- Os compostos inibidores agem principalmente de maneira competitiva (YANIV \& GILWARD, 1955).

Existem poucos trabalhos que referem-se diretamente à shiquimato desidrogenase como enzima associada a processo patogênicos ou de estresse em plantas. No entanto, a presença de compostos fenólicos e o acúmulo de escopoletina indicam que a via do ácido shiquímico possa estar sendo afetada sob estas condições (LOEBENSTEIN, 1972; BELL, 1981; LAMB et al., 1989; BOWLES, 1990; ENYEDI et al., 1992; FARMER \& RYAN, 1992).

A formação de escopoletina em tecidos infectados com VVCT, pode interferir nas reações normais que envolvem os derivados de fenil-propano, levando a alterações em diversas reações que envolvem a tirosina e a fenilalanina, alterando também a atividade de alguma enzima da via do ácido shiquimico (BEST, 1968). Em folhas atacadas por fungos patogênicos observouse um aumento na quantidade de fenilalanina, sendo que este aminoácido também foi encontrado em maior concentrą̧ão nas lesões quando comparadas ao tecido adjacente (BHASKARAN et al., 1974).

Em lesões geneticamente induzidas, pela presença do gene lls homozigoto recessivo, observa-se que ocorre acúmulo de fenilpropanóides, principalmente dos ácidos caféico e ferúlico, semelhantemente ao que ocorre por infecções patogênicas, indicando alterações bioquímicas nesta via metabólica na expressão dos sintomas (OBANNI et al., 1994). 
Por ser uma isoenzima de fácil deteç̧ão, a shiquimato desidrogenase tem sido muito usada como marcador molecular em estudos genéticos visando o melhoramento (ROSEMBERG et al., 1987; GRENECHE et al., 1991; HASHEMI et al., 1991; WESTPHAL \& WRICKE, 1991).

A atividade e a quantidade da fenilalanina-liase (PAL) são freqüentemente alteradas em processos de patogênese, sendo que a fenilalanina é o precursor de flavonóides, isoflavonóides e fitoalexinas (LAMB et al., 1989; BOWLES, 1990), mas observou-se também aumentos semelhantes nas concentraçōes de deidroshiquimato hidroliase e de shiquimato : NADP oxidorredutase (URITANI, 1971), indicando que a biossíntes dos aminoácidos aromáticos sofre alterações nestas situações.

No meio usado para uma cultura de callus de Papaver somniferum $\mathrm{L}$. foi adicionado um elicitor preparado a partir do micélio de Botrytis cinerea, e atividade específica da shiquimato desidrogenase e da PAL (fenilalanina liase) foram avaliadas. Observou-se que a quantidade de shiquimato desidrogenase não foi alterada, no entamto, não avaliou-se a presença de isoformas. (NADASKA \& ENDELSKI, 1991).

Portanto, pode haver alguma alteração na via do ácido shiquímico em casos de estresse biótico e abiótico, mas não obteve-se resultado satisfatório até o momento e as pesquisas referentes à shiquimato desidrogenase e sob estas condições não são freqüentes.

\subsubsection{Amilases}

As amilases (E.C. 3.2.1.1.) são encontradas em diversas partes das plantas, inclusive no mesófilo, e tem a função de hidrolisar o amido. Os dois principais tipos são $\alpha$-amilase e $\beta$-amilase, sendo esta classificação devido ao tipo de ligações que tem a capacidade de hidrolisar.

A caracterização das $\alpha$-amilase foi feita por SCHWIMMER \& BALLS (1949) e a da $\beta$ amilase por BALLS et al. (1948), sendo que entre suas características encontramos que o ion $\mathrm{Ca}^{+}$ tem a capacidade de aumentar sua atividade e a $\alpha$-amilase é mais resistente do que a $\beta$-amilase.

A associação das amilases com estados patogênicos em planta é relativamente antiga, uma vez que lesões locais não vistas a olho nu causadas pelo vírus do mosaico do fumo (TMV Tobamovirus) em folhas de abóbora, eram chamadas de "lesões de amido", pois podiam apenas ser observadas quando a folha era descolorada e tratada com iodo (LOEBENSTEIN, 1972). 0 
aumento no consumo de carboidratos em tecidos doentes, indicando uma maior atividade amilotítica também foi verificado (URITANI, 1981).

No entanto, BELL (1981) menciona vários trabalhos que relatam o acúmulo de amido nas células vizinhas às lesões necróticas, particularmente nos cloroplastos e nas bainhas vasculares.

$\mathrm{Na}$ formação de lesões locais em tecidos vegetais, também há um acúmulo de amido, sendo que a quantidade de açúcares (principalmente pentosess) é muito maior do que no tecido sadio, provocando um alteração na condição osmótica das células, formando estresses microambientais. Assim o papel das amilases em uma situação de ataque por patógeno seria hidrolisar 0 amido acumulado, neutralizando o efeito do gradiente osmótico (WAGIH \& COUTTS, 1982a).

Muitas semelhanças são observadas entre as amilase e outras proteínas relacionadas à patogênese : (1) localização apoplástica, (2) ponto isoelétrico ácido (pi $\cong 4,5)$, (3) alta resistência à ação de proteases, (4) baixa expressão em folhas sadias, (5) o mesmo padrão cinético de indução e (6) também podem ser induzidas por estresse hídrico, hormônios vegetais e senescência, sendo que as únicas diferenças observadas são que as amilases induzidas por vírus são menos abundantes e tem atividade enzimática altamente específica (HEITZ et al., 1991).

WAGIH (1992) observou alterações quantitativas e qualitativas nas isoenzimas amilase em cotilédones de abóbora infectados com vírus capaz de provocar reação necrótica. Estas alterações também foram observadas quando o material foi exposto a estresse abiótico. 0 autor afirma que o aumento na atividade da amilase resulta em acúmulo de açúcares, provenientes da hidrólise do amido, nas regiões afetadas.

Portanto, embora ainda não se saiba exatamente a função, o acúmulo de amido e de amilase ocorre freqüentemente em ataques por patógenos e mesmo em condições de estresse ambiental. 


\section{MATERIAL E MÉTODOS}

\subsection{Material Vegetal}

\subsubsection{Hospedeiros Utilizados}

Os trabalhos experimentais foram realizados nas instalações do Departamento de Química, setor de Bioquímica da ESALQ/USP em Piracicaba, de novembro de 1992 até novembro de 1994.

Foram utilizados vários hospedeiros durante o trabalho, sendo que suas respostas à presença do VVCT variaram desde aqueles que apresentam sintomas sistêmicos (altamente susceptível) até hipersensível (resistente).

O inóculo foi mantido em plantas de fumo (Nicotiana tabacum L.) do cultivar "Turkish NN", com sementes provenientes de material multiplicado no próprio laboratório. Este material foi utilizado para a referida função pois apresenta freqüentemente altos títulos de vírus e mostrase resistente ao vírus do mosaico do fumo -TMV (COSTA \& SILVA, 1989). O material exibe reação sensível ao VVCT, apresentando sintomas sistêmicos característicos.

Para a obtenção de protoplastos foram utilizadas apenas as plantas de fumo, pois, as demais hospedeiras cultivadas apresentam problemas para a manutenção em cultura de suspensão na forma de protoplastos.

Também utilizou-se plantas de tomate (Lycopersicum esculentum Mill.) do grupo Santa Cruz, cultivar comercial "Kada" (AGROCERES), que mostra-se altamente susceptivel apresentando sintomas sistêmicos. A petúnia (Petunia hybrida Vilm.) do cultivar comercial hybrida (AGROCERES) foi usada como hospedeira exibindo resposta hipersensivel ao VVCT, pois quando inoculada, o vírus não tem a capacidade de provocar sintomas sistêmicos, causando apenas lesões necróticas típicas. 
Para certificar-se de que o vírus não havia sofrido nenhuma contaminação durante os experimentos, urna vez por mês foram inoculadas plantas de feijão (Phaseoulus vulgaris L. cv. "manteiga") e caupi (Vigna unguiculata (L.) Walp. cv. "fradinho") que são consideradas hospedeiras diferenciais do VVCT.

\subsubsection{Condições de Manutenção dos Hospedeiros}

O material vegetal foi mantido em casa-de-vegetação sob condições ambiente de luminosidade e temperatura (média anual de $21,5^{\circ} \mathrm{C}$, sendo as médias 29 e $14^{\circ} \mathrm{C}$, nos meses mais quentes e nos mais frios, respectivamente).

Foram utilizadas sementeiras rasas contendo húmus e solo de textura arenosa na proporção $1: 3$. As plantas de fumo foram transplantadas das sementeiras 4 a 6 semanas após a semeadura, as plantas de tomate 3 a 5 semanas e as plantas de petúnia de 6 a 8 semanas. 0 feijão e o caupi não foram semeados em sementeiras, mas diretamente nos vasos idênticos às outras plantas. Foram colocadas 8 sementes de feijão ou caupi por vaso e após a emergência foi realizado o desbaste para 4 plantas por vaso.

As plântulas foram plantadas em vasos com capacidade para $2 \mathrm{~L}$, contendo solo de textura mista e húmus na proporção $3: 2$, tendo sido previamente adubados (15 dias antes do plantio) com N : P : K (10:10:10) e Nitrocálcio.

A densidade de plantio do fumo e do tomate foi de 2 plantas viáveis por vaso, para petúnia de 1 planta viável por vaso e para o feijão e caupi 4 plantas viáveis por vaso, conforme anteriormente mencionado.

O material vegetal foi irrigado 2 vezes por dia, uma vez no início da manhã e outra no final da tarde, durante os períodos de verão e apenas uma vez por dia no invemo.

Para tentar evitar uma elevação na temperatura, durante o verão, os vasos permaneceram cobertos por tela "Sombrite", com 60 \% de sombreamento e resistente a raios uv (Equipesca).

\subsection{Inoculação do VVCT na plantas hospedeiras}

Folhas com sintomas cloróticos, necróticos e sistêmicos nítidos foram retiradas das plantas usadas como fonte de inóculo e maceradas em almofariz refrigerado a $4^{\circ} \mathrm{C}$, em um recipiente contendo gelo para manter a temperatura baixa. 
Esta maceração foi feita em presença de tampão fosfato $110 \mathrm{mM}$ com sulfito de sódio 7 $\mathrm{mM}$ como agente antioxidante e pH 7,2. $\mathrm{O}$ tampão também foi mantido a $4^{\circ} \mathrm{C}$ até o momento da maceração. $\mathbf{O}$ extrato vegetal assim obtido foi filtrado em duas camadas de tecido e mantido a $4^{\circ} \mathrm{C}$ até o momento da inoculação, sendo que esta deveria ser realizada o mais rápido possível.

Plantas com 2 a 4 semanas (tomate), 4 a 6 semanas (fumo e petúnia) após transplante foram inoculadas mecanicamente com VVCT. Foram inoculadas duas folhas opostas por planta, usando carborundo (mesh 500) como agente abrasivo e o extrato vegetal resfriado como inóculo de vírus. Três minutos após a inoculação as folhas foram intensamente lavadas com água destilada.

As inoculações foram preferencialmente realizadas nos períodos de temperaturas mais amenas do dia, e durante o verão, logo após a inoculação as plantas foram mantidas, por um dia, sob proteção da luz solar direta, permanecendo sob a bancada de sustentação dos vasos. 0 material vegetal sadio também foi inoculado com tampão sem a presença do VVCT.

\subsection{Aplicação de Ribavirina}

Das plantas inoculadas, uma parte foi separada para receber tratamento com ribavirina. Foram mantidos períodos de 15 minutos até 1 hora desde a inoculação com VVCT até a aplicação da ribavirina.

A ribavirina (Intemational Chemical and Nuclear Corporation - ICN Pharmaceutics, Irvine, Califomia, através de ICN Produtos Farmaceuticos Ltda., Rio de Janeiro) foi diluída em água destilada até a concentração $250 \mu \mathrm{g} / \mathrm{mL}$, que foi posteriormente aplicada nas folhas através de pulverizações, sendo que cada planta recebeu um volume aproximado de $20 \mathrm{~mL}$. As plantas pulverizadas foram mantidas sob proteção da luz solar direta (sob a bancada) e especialmente, afastadas das demais para evitar que a ribavirina entrasse em contato com as outras plantas.

A pulverização com ribavirina não se restringiu às folhas inoculadas, de modo que a planta toda foi pulverizada indistintamente. Estas plantas foram destinadas à obtenção de proteínas solúveis para análise dos perfis isoenzimáticos.

Os cultivos de protoplastos em suspensão receberam, a partir do primeiro dia, $150 \mathrm{mg}$ de ribavirina / $\mathrm{mL}$ de meio de cultura, sendo que a concentração foi alterada com o tempo, pois o material recebeu meio fresco a intervalos constantes de dois dias, sendo que a concentração final de ribavirina foi $1,67 \mathrm{mg} / \mathrm{mL}$. 


\subsection{Obtenção e Cultivo de Protoplastos}

\subsubsection{Protoplastos do mesófilo de fumo (Nicotiana tabacum L.)}

As soluções e meios utilizados, quando diferentes dos propostos por MURASHIGE \& SKOOG (1962), estão listados no Apêndice 1.

Os protoplastos foram obtidos através do método enzimático proposto por COCKING (1960), sendo que algumas alterações foram realizadas no procedimento, conforme mencionado a seguir.

As folhas foram retiradas das plantas e sofreram atamento com hipoclorito de cálcio $4 \%$ (Pool Tract pureza 65\%, marca Gemco ) por 3 a 5 minutos para sua assepsia superficial. Para as repetições foram escolhidos materiais vegetais com características fisiológicas, morfológicas e de distribuição e intensidade de sintomas idênticas, procurando-se reduzir ao máximo a influência do resíduo na análise estatística.

O material foi finamente cortado em tiras sob condições assépticas, em câmara de fluxo laminar previamente desinfetada com formaldeído e hipoclorito de sódio comercial, e imerso na solução de enzimas lítica dissolvidas em meio de maceração, que havia sido anteriormente esterilizada por filtração a vácuo em filtro de nitrocelulose com poros de $0,22 \mu \mathrm{m}$ de diâmetro, a fim de evitar contaminação por microrganismos em geral.

O material vegetal permaneceu na solução de maceração com as enzimas líticas por um período múnimo de 16 horas dependendo das enzimas lítica serem reutilizadas ou não, sendo que iluminação e altas temperaturas foram evitadas neste intervalo de tempo.

A solução de enzimas líticas, após o período de maceração e quando do isolamento dos protoplastos, foi filtrada conforme procedimento anterior e mantida a $-20^{\circ} \mathrm{C}$ para reutilização em outros processos de protoplastização.

Posteriormente, o macerado foi transferido para tubos de centrífuga autoclavados, sob condições assépticas em câmara de fluxo laminar. 0 líquido foi centrifugado por 1 a 3 minutos, a $100 \mathrm{x} \mathrm{g}$. 0 sobrenadante foi retirado e o mesmo procedimento foi repetido. $\mathrm{O}$ sobrenadante desta última centrifugação contendo os protoplastos viáveis foi incubado em tubos de ensaio autoclavados com $5 \mathrm{~mL}$ de meio de cultura. 
Os tubos permaneceram no escuro e foram mantidos sob agitação constante, de modo a melhorar a aeração do cultivo e evitar a formação de agregados de protoplastos. A suspensão foi conduzida como uma batelada alimentada, pois a intervalos de 2 dias os cultivos recebiam volumes progressivamente maiores de meio fresco.

Os cultivos conduzidos como bateladas alimentadas duraram, em média, 19 dias, sem que houvesse a presença de microrganismos contaminantes, mas no material tratado com ribavirina foi necessária a adição de antibiótico para prevenir a contaminação do meio por leveduras. 0 antibiótico usado foi nistatina ( Ducto Indústria Farmaceutica Ltda., Anápolis, Goiás), sendo que o efeito da presença do antibiótico na concentração utilizada ( $20 \mu \mathrm{L} / \mathrm{mL}$ de meio) não afetou significativamente o desenvolvimento dos protoplastos como observado em teste preliminar.

\subsubsection{Avaliação da cinética de crescimento dos protoplastos em cultivo de suspensão}

\section{a) Método Direto}

Pelo método direto, foram retiradas alíquotas de $2 \mathrm{~mL}$ dos cultivos em suspensão, sob condições assépticas em câmara de fluxo laminar. Estas alíquotas foram tratadas com azul de metileno por 5 minutos para que os protoplastos viáveis pudessem ser reconhecidos devido a sua coloração amarela indicando maior poder redutor das células viáveis quando comparando-se com as células morta que permanecem azuis, e contados em Câmara de Neubauer ao microscópio óptico.

Levando-se em consideração as dimensões da Câmara de Neubauer e as diluições do cultivo durante o passar do tempo, foi obtido o número de protoplastos viáveis presentes em intervalos de dois em dois dias durante o experimento.

Cada contagem foi repetida quatro vezes a fim de obter-se um valor mais seguro para cada observação, sendo que os valores associados ao tempo de cultivo tiveram mais onze repetições para o material tratado com ribavirina e sete para o material não-tratado. Este procedimento, estatisticamente recomendado visou reduzir os efeitos do resíduo sobre a análise dos dados. 


\section{b) Métodos Indiretos}

\section{b.1) Densidade Óptica}

Um método indireto para avaliação do crescimento dos protoplastos em cultivo em suspensão foi a medida da densidade óptica de alíquotas, retiradas do cultivo a 2 dias de intervalo de tempo, em espectrofotômetro a um comprimento de onda conhecido $(\lambda=490 \mathrm{~nm})$. De modo que a medida que a quantidade de protoplastos presentes no cultivo aumentava, o correspondente ocorreria com a densidade óptica da alíquota, possibilitando a obtenção de uma curva de crescimento semelhantemente ao método anterior.

\section{b.2) Medida da Corda (W)}

Esse método indireto foi proposto por GILISSEN et al. (1983), sendo que a quantidade de protoplastos presentes no cultivo foi avaliada a partir do Volume de Células Precipitadas (VCP) que foi obtido indiretamente por uma relação entre este valor e o comprimento da corda formada pelos protoplastos precipitados (W) quando o recipiente de cultivo é inclinado de acordo com uma reta de calibração.

Mantendo-se constantes os valores de $\mathbf{h}$ e $\mathbf{m}$ do esquema, a inclinação do frasco também será constante em função dos ângulos do triângulo retângulo formado, o que nos dará uma calibração precisa e passível de repetição toda vez que quisermos alguma medida de $\mathbf{W}$.

A equivalência entre W e VCP é dada pela equação :

$$
\log \mathrm{VCP}=\mathrm{A}+\mathrm{BW}
$$

onde : $A=$ ponto onde a equação de regressão intercepta o eixo y (termo independente)

B = é o ângulo de inclinação da equação de regressão

Os valores de a e b são calculados estatisticamente por fórmulas de regressão linear.

Biologicamente, o valor de $\mathbf{A}$ é equivalente ao inóculo inicial $\left(\mathrm{x}_{0}\right)$ presente em um cultivo de protoplastos em suspensão no momento em que o tempo é igual a zero $(t=0)$ e o valor de $B$ eqüivale a velocidade de crescimento dos protoplastos. 
A taxa de aumento de biomassa por unidade de tempo $\left(\mathrm{RGR}_{\mathrm{t}}\right)$ do cultivo também pode ser obtida através da equação :

$$
\mathrm{RGR}_{\mathrm{t}}=\mathrm{b} \mathrm{d} / \mathrm{dt} \mathrm{W}_{\mathrm{t}}
$$

eqüivalentemente, se incorporarmos (1) em (2) temos :

$$
\mathrm{RGR}_{\mathrm{t}}=\mathrm{d} / \mathrm{dt} \log \mathrm{W}_{\mathrm{t}}
$$

onde : $\mathrm{W}_{\mathrm{t}}=$ comprimento da corda formada pelos protoplastos quando o frasco é inclinado de acordo com uma dada calibração em um tempo $t$ do cultivo.

A figura 2 ilustra esquematicamente o procedimento para a obtenção de $\mathbf{W}$ e a figura 3 mostra o posicionamento dos frascos erlenmeyers para as leituras.

$\mathbf{O}$ valor de $\mathbf{W}$ foi medido com paquímetro, sendo que cada medida teve quatro repetições.
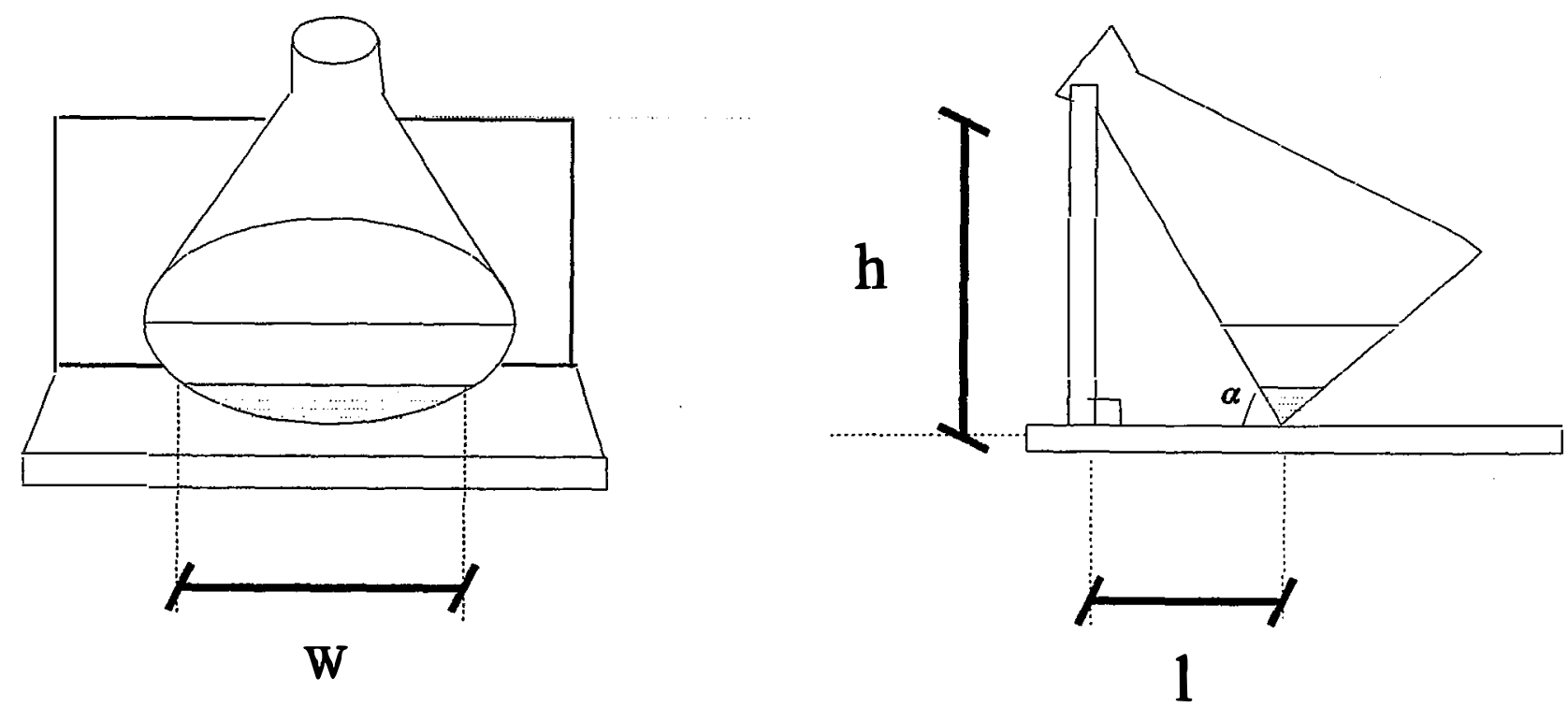

Figura 2 : Diagrama esquemático do posicionamento dos frascos erlenmeyer e da posição dos protoplastos (pontos) durante a medida de $\mathbf{W}$. Os valores de $\mathbf{l}$ e h são constantes da reta de calibração. 

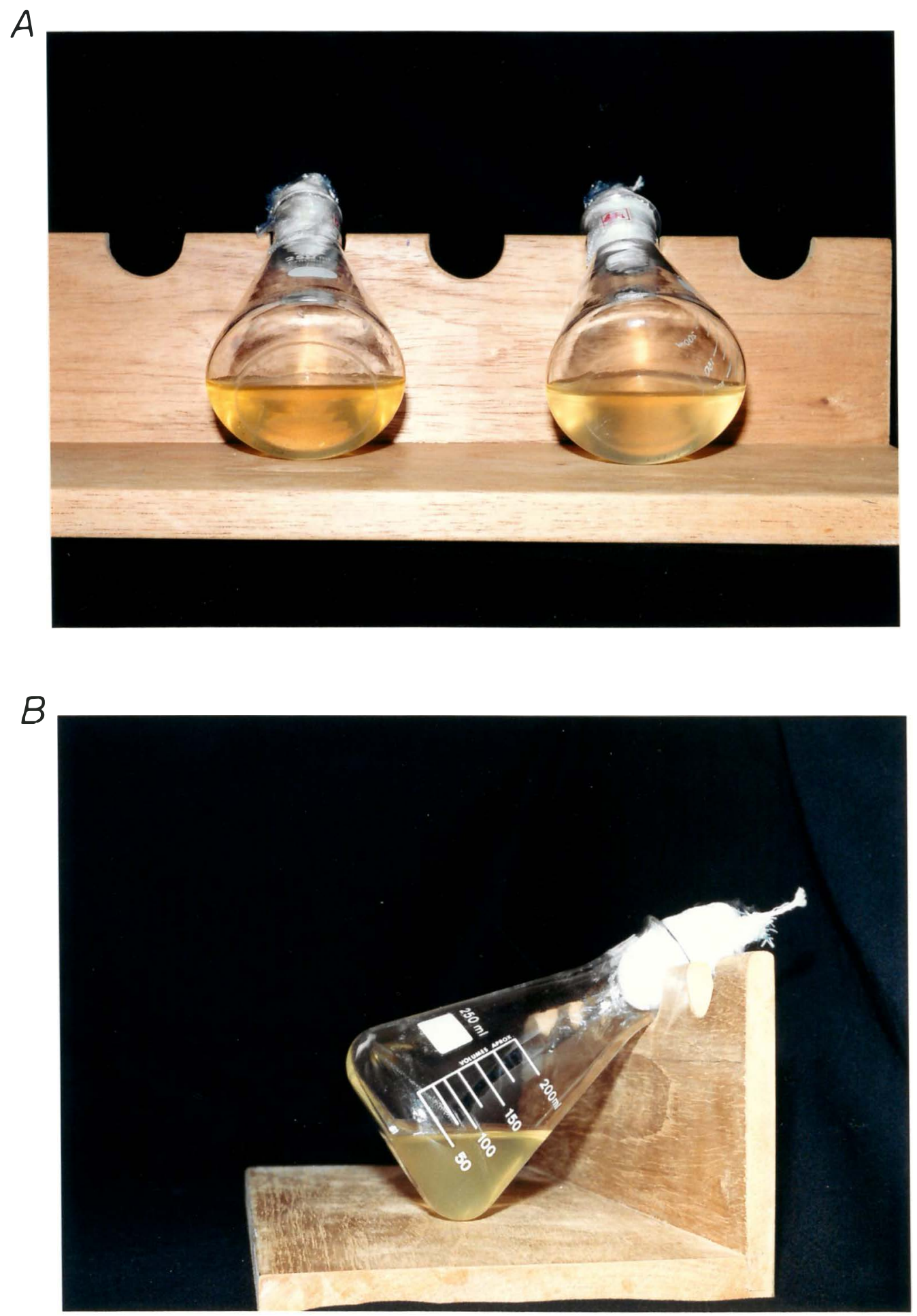

Figura 3 : (A) Vista frontal e (B) vista lateral do posicionamento dos erlenmeyeres para a leitura do comprimento $\mathbf{W}$ da corda formada pelos protoplastos precipitados. A inclinação constante permite a obtenção da reta de calibração. 


\subsection{Extração das Proteínas Totais Solúveis da Parte Aérea dos Hospedeiros}

\subsubsection{Proteínas armazenadas sob congelamento}

As proteínas solúveis totais foram extraídas de folhas dos três hospedeiros : fumo, tomate e petúnia, com o período médio de 3 a 4 semanas após a inoculação. 0 mesmo procedimento foi seguido para as folhas dos hospedeiros sadios, infectados com VVCT e infectados e tratados com ribavirina. No caso de petúnia (hipersensibilidade ao vírus) foram utilizadas apenas as folhas com lesões necróticas locais, uma vez que não apresenta sintomas sistêmicos por todo o corpo do vegetal.

Uma quantidade de $2 \mathrm{~g}$ de folhas com sintomas característico para cada hospedeiro foi destacada e triturada em almofariz com excesso de nitrogênio líquido $\left(\mathrm{N}_{2}\right)$. O pó resultante foi tratado com acetona resfriada a $-20^{\circ} \mathrm{C}$ para a remoção de pigmentos. A acetona foi evaporada das amostras e obteve-se um pó que foi solubilizado no tampão de extração contendo TRIS-HCl (Apêndice 2). 0 material homogeneizado foi centrifugado por 90 minutos a $4000 \times \mathrm{g}$ em rotor mantido a $-20^{\circ} \mathrm{C}$ por 12 horas.

Após a centrifugação, o precipitado foi descartado e o sobrenadante contendo as proteínas solúveis foi mantido em congelador a $-20^{\circ} \mathrm{C}$ até o momento de sua utilização. Este procedimento de extração foi usado para a obtenção dos perfis eletroforéticos das isoformas de peroxidases e de shiquimato desidrogenases.

\subsubsection{Proteínas Cruas}

As proteínas usadas para avaliação das isoformas de amilases não puderam ser congeladas para utilização posterior, pois ocorre perda de atividade destas isoenzimas devido a alterações conformacionais na molécula. Os critérios para escolha do material vegetal a sofrer extração foram os mesmos mencionados no item precedente.

Utilizou-se, portanto, o método proposto por WAGIH (1992) com algumas modificações : a homogeneização do tecido vegetal com o tampão de extração utilizado no presente trabalho foi na proporção de $1: 2$ (relação peso/volume), visando uma maior solubilização das proteínas presentes no tecido. Os homogenatos foram centrifugados a $4500 \times \mathrm{g}$ por 2 horas em rotor mantido a $-20^{\circ} \mathrm{C}$ por 12 horas. 


\subsection{Eletroforese das proteínas solúveis totais em gel de poliacrilamida (PAGE) e de poliacrilamida e amido}

Amostras de proteinas solúveis totais de folha dos hospedeiros infectados ou não $\mathrm{e}$ tratados ou não com ribavirina, foram submetidas a eletroforese em gel de poliacrilamida em sistema descontínuo não-desnaturante (LAEMMLI, 1970).

O sistema foi constituido por dois géis : o gel de resolução contendo $12 \%$ de poliacrilamida para as isoenzimas de peroxidases e shiquimato desidrogenases e contendo $10 \%$ de poliacrilamida $+0,1 \%$ de amido solúvel para as isoamilases e o gel de empacotamento ('stacking gel") contendo $6 \%$ de poliacrilamida para géis de resolução com $12 \%$ de poliacrilamida e sem amido e contendo $4 \%$ de poliacrilamida para os géis de resolução contendo $10 \%$ de poliacrilamida e $0,1 \%$ de amido.

As amostras de proteína foram quantificadas pelo método de BRADFORD (1976), usando padrão de albumina do soro bovino. As amostras foram aplicadas a concentrações constantes e iguais a $15 \mathrm{mg}$ de proteína/ $\mathrm{mL}$, ou seja, aproximadamente $25 \mu \mathrm{g} /$ canaleta.

As eletroforeses foram conduzidas em placa vertical, a $150 \mathrm{~V}(50 \mathrm{~mA})$ por uma hora e meia

Cada gel foi corado de acordo com os procedimentos indicados para a isoenzima que estava sendo analisada.

Os pesos moleculares das proteinas resolvidas pela eletroforese foram calculados através do uso de um padrão de peso molecular que foi corrido sob as mesmas condições.

\subsection{Coloração das Peroxidases, Shiquimato Desidrogenases e Amilases nos géis}

\subsubsection{Peroxidases}

A coloração para estas isoenzimas foi feita de acordo com o procedimento proposto por HAMMERSCHMIDT et al. (1982) e modificado por ALFENAS et al. (1987).

Após a corrida, o gel foi incubado a $30^{\circ} \mathrm{C}$ em uma solução contendo : $O$-dianisidina di$\mathrm{HCl}$, tampão acetato a $0,1 \mathrm{M}$ e pH 4,5 e $\mathrm{H}_{2} \mathrm{O}_{2} 3 \%$. Para cada $20 \mathrm{~cm}^{2}$ de gel foram usados 100 $\mathrm{mL}$ de solução. 
Aproximadamente após 30 minutos de incubação as bandas aparecem, portanto a solução reveladora com o substrato pode ser descartada e o gel fixado com uma solução aquosa de glicerol a $10 \%$.

\subsubsection{Shiquimato Desidrogenases}

0 procedimento mais eficiente para a coloração das isoformas desta enzima, foi o proposto por VALLEJOS (1983).

De acordo com esta metodologia, logo após a corrida o gel é incubado no escuro a $30^{\circ} \mathrm{C}$ por um intervalo de 30 a 60 minutos em uma solução contendo : ácido shiquímico, NADP ${ }^{+}$, MTT e PMS dissolvidos em TRIS-HCl 0,1 M e pH 7,5. Foram usados $100 \mu \mathrm{L}$ de solução para $20 \mathrm{~cm}^{2}$ de gel.

Após o surgimento das bandas a solução reveladora é descartada e o gel fixado com fixativo PAGE, contendo etanol, ácido acético, glicerol e água na proporção $10: 4: 2: 8$, em volume.

\subsubsection{Amilases}

0 material corrido em gel com $0,1 \%$ de amido solúvel, foi corado de acordo com a metodologia de WAGIH (1992).

0 gel foi incubado em solução aquosa de ácido acético a $7 \%$ contendo $0,006 \mathrm{M} \mathrm{de} \mathrm{NaCl}$, a temperatura ambiente por 30 minutos. Depois disto, a solução ácida foi descartada e o gel intensamente lavado em água destilada e deionizada. A seguir o gel foi colocado em $50 \mathrm{ml}$ de solução de Iodo $2 \%$ e KI $6 \%$ (1 : 1, em relação volume/volume).

As bandas surgiram claras no fundo escuro (azul) do gel, devido a esta ser uma coloração negativa.

0 gel foi posteriormente fixado em solução aquosa de glicerol a $10 \%$. 


\subsection{Impressão das Proteínas do Tecido Vegetal em Membranas de Nitrocelulose (“tissue-blot")}

Folhas apresentando sintomas cloróticos, necróticos e/ou sistêmicos distintos foram mantidas sob temperatura de $-20^{\circ} \mathrm{C}$, envolvidas em filme de PVC, durante 4 horas. Este procedimento provoca o rompimento das células pela formação lenta de grandes cristais de gelo no seu interior, facilitando a liberação das proteínas.

Após o período de congelamento, as folhas foram mantidas à temperatura ambiente por 5 minutos para descongelar, sendo em seguida colocadas sobre as membranas. Os "blots" em membranas de nitrocelulose com poros de $45 \mu \mathrm{m}$ de diâmetro ( Sigma para Biologia Molecular, $33 \mathrm{~cm} \times 3 \mathrm{~m}$ ), foram feitos de acordo com HSU \& LAWSON (1991), mas sem a necessidade de seccionar o tecido, pois a liberação das proteínas foi facilitada pelo processo de descongelamento.

O tempo de impressão foi variável, de acordo com o material vegetal utilizado em função da suculência da folha a ser impressa. Para follhas com textura lisa e maior suculência, como petúnia e fumo, 1 a 1,5 minutos sob pressão intensa ( $\cong 500 \mathrm{kgf}$ ) e constante foi suficiente, enquanto que para o material com textura mais irregular e menor suculência, 2 a 3 minutos sob as mesmas condições foram indicados.

As impressões nas membranas foram visualizadas sob luz ultravioleta, e quando foi possível a observação dos detalhes e da textura presentes na folha in vivo no "blot", a impressão foi considerada adequada. Caso contrário, o material foi inutilizado e o procedimento repetido.

A fixação das proteínas vegetais nas membranas foi feita a temperatura ambiente por 15 a 30 minutos. Não houve a necessidade de fixação em estufa com temperaturas mais elevadas, mas recomenda-se manter as membranas protegidas por tampas de placas de Petri de vidro ou simplesmente cobertas com papel filtro, evitando o contacto das proteinas fixadas com o ambiente e impedindo que a membrana sofra colorações indesejáveis devido a sujeira que possam interferir posteriormente na interpretação dos "blots". 


\subsection{Coloração das Peroxidases, Shiquimato Desidrogenases e Amilases Impressas sobre Membranas de Nitrocelulose}

Os procedimentos para a coloração das isoformas de peroxidases e shiquimato desidrogenases impressas sobre membranas de nitrocelulose, foram idênticos aos utilizados para os géis, sendo que a única diferença foi que a quantidade de solução contendo o substrato foi de 100 a $200 \mu \mathrm{L}$ por $\mathrm{cm}^{2}$ de membrana, para evitar que o excesso de solução pudesse "lavar" as proteinas da superficie da membrana.

Para as isoenzimas da amilase, o procedimento foi diverso do utilizado para géis, uma vez que este não foi eficiente para as condições de "blots" em membrana de nitrocelulose, sendo o procedimento baseado em WAGIH (1992) com as alterações mencionadas a seguir.

Após a fixação na membrana, o material para as amilases foi incubado por duas horas a temperatura constante de $30^{\circ} \mathrm{C}$ em uma solução $7 \%$ de ácido acético contendo $0,2 \mathrm{M}$ de $\mathrm{CaCl}_{2}$, na proporção de 100 a $200 \mu \mathrm{L}$ por $\mathrm{cm}^{2}$ de membrana. Posteriormente, o excesso de solução foi retirado colocando-se a membrana sobre uma camada de "papel-chupão" ou sobre 4 camadas de papel de filtro comum. Depois de seca, a membrana foi mergulhada por 15 minutos em uma solução de amido a $0,5 \%$ e mantida, por mais 15 minutos, sobre uma superficie lisa e nãoabsorvente para drenar o excesso de amido.

A membrana já drenada foi, então, imersa em solução de Iodo $2 \%$ e KI $6 \%$ (1 : 1, em relação de volume/volume), de modo que as zonas de atividade da amilase aparecessem mais claras sobre o fundo azul da membrana (coloração negativa).

Quando um excesso de amido sobre a membrana foi observado, esta foi gentilmente lavada em água destilada e deionizada até que o excesso foi removido e a atividade das isoformas da amilase pôde ser visualizado.

Além do procedimento anteriormente mencionado, também foi testado o método proposto por VALLEJOS (1983). 


\section{RESULTADOS}

\subsection{Cinética de Crescimento de Protoplastos em Cultivo de Suspensão}

\subsubsection{Método Direto}

A avaliação da cinética de crescimento dos protoplastos em cultivo de suspensão pelo método direto, ou seja, contagem de protoplastos viáveis ao microscópio óptico, mostrou que o padrão de crescimento deste material segue uma curva bacteriana de crescimento, sendo distinta a presença de uma "fase lag" no início, seguida de uma fase de crescimento exponencial ("fase log") e posteriormente uma fase final com tendência à estabilidade ou ao declínio (figura 4).

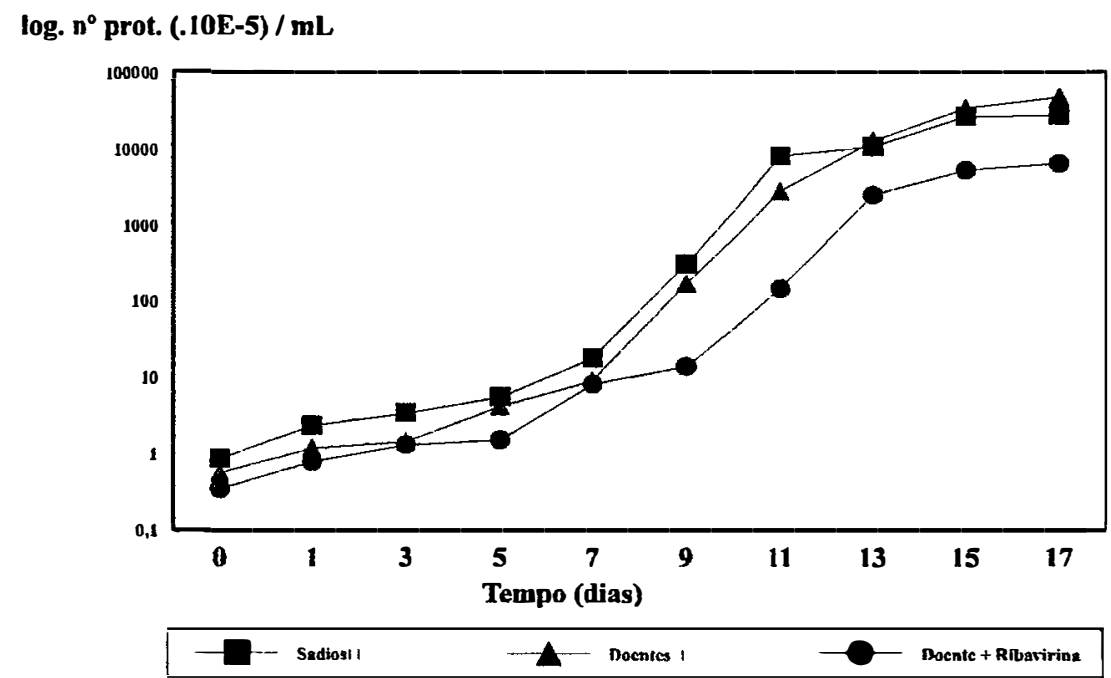

Figura 4 - Curvas de crescimento de protoplastos de mesófilo de Nicotiana tabacum sadios e infectados com VVCT e infectados e tratados com ribavirina em cultivo de suspensão, representadas como contagens obtidas pelo método direto. 
Os dados foram analisados de acordo com análise de variância para efeito dos tratamentos e análise de variância para efeito da regressão logarítmica, através do teste estatístico de $\mathrm{F}$, aos níveis de probabilidade $\mathrm{P}>95 \%$ e $\mathrm{P}>99 \%$ para todos os contrastes testados.

Todos os materiais testados apresentaram alta correlação quando usou-se uma regressão linear com transformação logarítmica para expressar o seu crescimento em suspensão, considerando-se a medida do tempo em dias como o valor de $\mathrm{x}$ e o número de protoplastos presentes na suspensão como o valor de y. Matematicamente, a equação de regressão utilizada foi $\log \mathrm{y}=\mathbf{A}+\mathbf{B x}$, onde as constantes A e B representam : o terno independente, ou seja o ponto onde o gráfico corta o eixo y, e a tangente do ângulo horizontal da reta, respectivamente. Nenhum outro tipo de regressão mostrou efeito significativo para os dados analisados.

Não se observou efeito significativo da interação entre os tratamentos (presença do vírus e tratamento com ribavirina) aos níveis de $\mathbf{P}<0,05$ e $\mathbf{P}<0,01$. A significância da regressão foi alta, concordando com o coeficiente de correlação que foi em todos os casos superior a $96 \%$, como apresentado na tabela 1.

Tabela 1 : Equações de regressão logaritmica, coeficientes de correlação e significância estatística da regressão para o crescimento de protoplastos de mesófilo de Nicotiana tabacum L. em suspensão cultivados in vitro.

\begin{tabular}{|c|c|c|c|}
\hline Material & Equação de Regressão & Coef. de Correlação (r) & Significância Estatística \\
\hline Sadio & $\log \mathrm{y}=-5,455+0,310 \mathrm{x}$ & 0,9698 & $*$ \\
\hline Sadio + Ribavinina & $\log \mathrm{y}=-5,894+0,265 \mathrm{x}$ & 0,9785 & $*$ \\
\hline Doente & $\log \mathrm{y}=-5,757+0,334 \mathrm{x}$ & 0,9835 & $*$ \\
\hline Doente + Ribavinina & $\log \mathrm{y}=-5,895+0,271 \mathrm{x}$ & 0,9642 & $*$ \\
\hline
\end{tabular}

A significância estatística da correlação foi avaliada pelo teste $F$ e as equações assinaladas por $\left(^{*}\right)$ indicam significância estatística para $P<0,05$, o sinal $\left(^{* *}\right)$ indica alta significância, nível de probabilidade $P<0,01$.

As regressões logarítmicas dos contrastes de média estatisticamente significativos estão apresentadas na figura 5 . 
log. $\mathrm{n}^{0}$ prot. (.10E-5) / mL

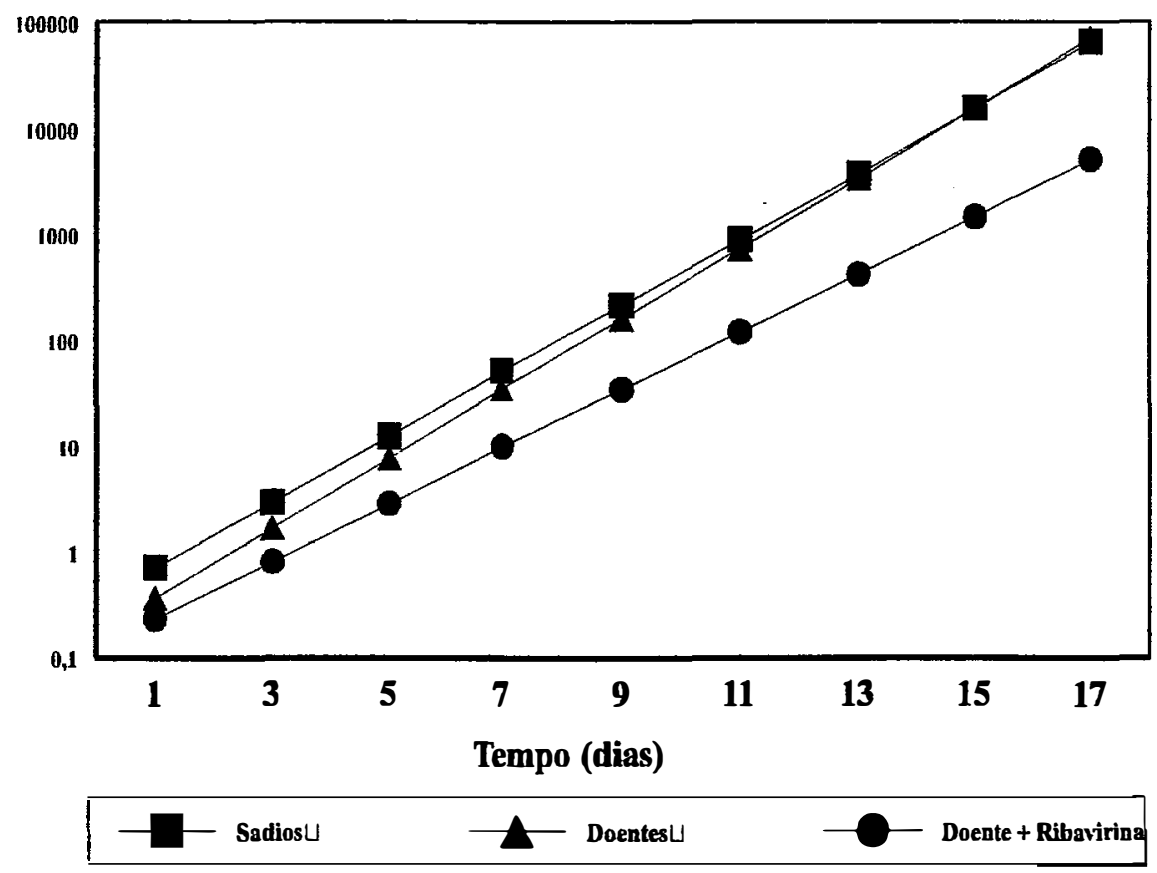

Figura 5 - Curvas de crescimento de protoplastos de mesófilo de Nicotiana tabacum sadios e infectados com VVCT e tratados com ribavirina em cultivo de suspensão, representado como regressão linear com transformação logarítmica.

O contraste de médias entre os materiais Sadios (S), Doentes (D), Sadios + Ribavirina (SR) e Doente + Ribavirina (DR) mostrou que houve diferença estatística significativa, ao nível de $\mathrm{P}<0,05$, entre o material sadio e o doente e entre o sadio e o doente tratado com ribavirina, como demonstra a tabela 2. As médias do material sadio foram consideradas como o parâmetro normal para o crescimento de protoplastos em suspensão, uma vez que as condições proporcionadas foram mantidas constantes e foram consideradas como ideais. 
Tabela 2 : Comparação dos contrastes de médias através do teste $\mathrm{F}$ para todos os tratamentos a nível de $95 \%$ de probabilidade.

\begin{tabular}{|c|c|}
\hline Contraste de Médias & Significância $(\mathbf{P}<\mathbf{0 , 0 5})$ \\
\hline Sadio x Doente & $*$ \\
\hline Sadio x Sadio com Ribavinina & $*$ \\
\hline Sadio x Doente com Ribavinina & n.s. \\
\hline Doente x Sadio com Ribavirina & n.s. \\
\hline Doente x Doente com Ribavirina & n.s. \\
\hline Sadio com Ribavirina x Doente com Ribavinina & \\
\hline
\end{tabular}

Os contrastes, comparados através do teste $F$, marcados com $\left(^{*}\right)$ indicam significância estatística ao nível de probabilidade mencionado, enquanto que os contrastes assinalados com (n.s.) indicam inexistência de significância estatística para o mesmo nível de probabilidade.

As diferenças significativas entre o contraste de médias $S \times D$ e $S \times D R$, estão representadas na figura 5 .

Os valores dos intervalos de confiança para cada média aos níveis de $95 \%$ e $99 \%$ de probabilidade estão listados no Apêndice 3 , juntamente com os valores da variância e desviopadrão dos experimento total.

\subsubsection{Métodos Indiretos}

\subsubsection{Densidade Óptica}

Os dados obtidos a partir das densidades ópticas do cultivo, lida em espectrofotômetro a um comprimento de onda conhecido $(\lambda=490 \mathrm{~nm})$ e descontando-se a dispersão de luz (NOORDAM, 1973), foram analisados semelhantemente aos anteriores.

Não observou-se nenhum efeito significativo quanto aos tratamentos utilizados, tanto a nível de $\mathrm{P}>0,05$ quanto a $\mathrm{P}>0,01$, além disso não obteve-se nenhum efeito significativo, aos mesmos níveis de probabilidade, para nenhum tipo de regressão testada : linear, logaritmica, logaritmica neperiana e quadrática. 
A tendência dos pontos de densidade óptica representada graficamente contra o tempo está apresentada na figura 6.

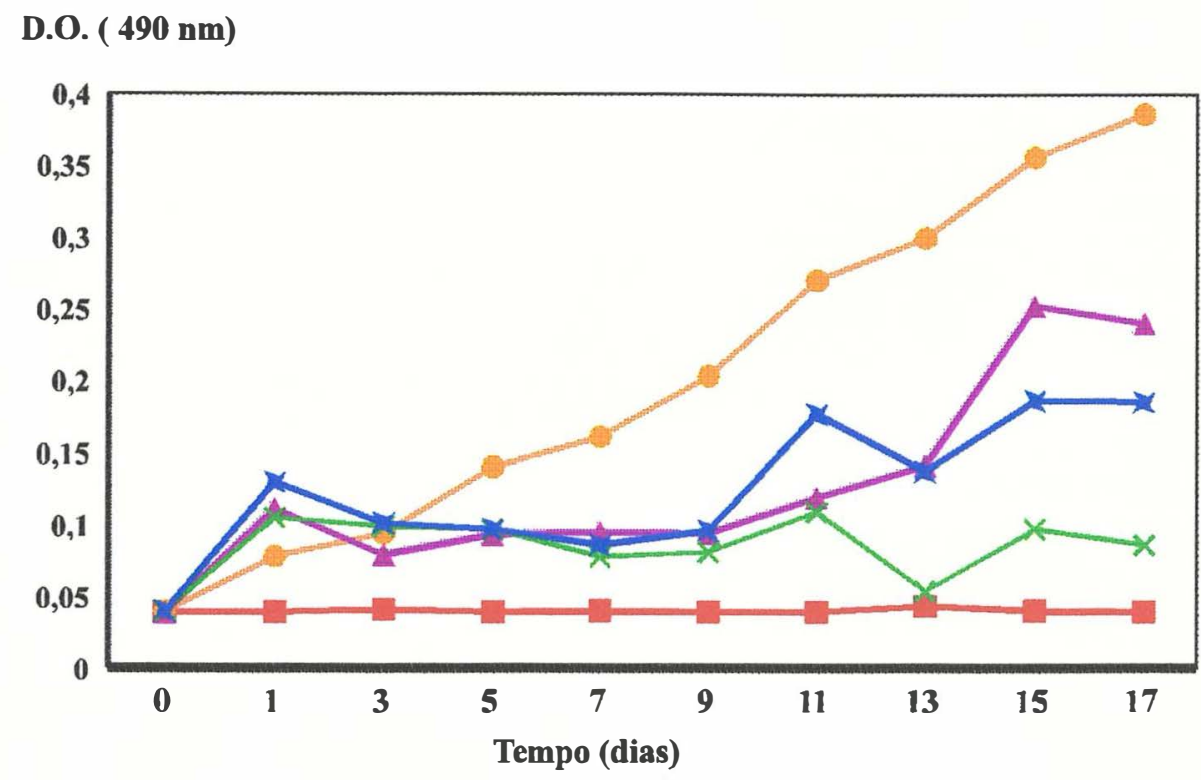

- Meio $-\mathrm{S} \quad-\mathbf{t}+\mathbf{R} \rightarrow \mathbf{D} \rightarrow \mathrm{D}+\mathrm{R}$

Figura 6- Curvas de densidade óptica (descontando-se o valor da dispersão luminosa) dos tratamentos : sadio (S), doente (D), sadio + ribavirina $(\mathrm{S}+\mathrm{R})$ e doente + ribavirina $(\mathrm{D}+$ R) no tempo, dado em dias.

A variância total do experimento total também atingiu um valor maior do que o recomendado para o número de repetições usadas e para o número de tratamentos testados, aumentando a influência do resíduo no experimento. A análise estatística, juntamente com os dados das leituras estão apresentados no Apêndice 3 (tabela 10).

\subsubsection{Medida do Comprimento da Corda (W)}

Os dados foram analisado estatisticamente como os anteriores. Também foi possível observar-se que o aumento do valor de $\mathrm{W}$ relacionou-se à passagem do tempo de forma linear.

A correlação linear entre o aumento de W (valor y) e o tempo (valor $x$ ) foi alta ( $r>90 \%$ ) para todos os contrastes testados. 
As outras correlações testadas, ou seja, logarítmica, logarítmica neperiana e quadrática, não foram significativas ao nível de $P<0,05$, mostrando que a equação linear descreveu bem 0 fenômeno ( tabela 3).

Tabela 3 : Equações de regressão linear, coeficientes de correlação e significância estatística da regressão para o crescimento de protoplastos de mesófilo de Nicotiana tabacum L. em suspensão cultivados in vitro.

\begin{tabular}{|c|c|c|c|}
\hline Material & Equação de Regressão & Coef. de Correlação (r) & Significância Estatística \\
\hline Sadio & $\mathrm{y}=0,6175+0,3503 \mathrm{x}$ & 0,9852 & $*$ \\
\hline Sadio + Ribavinina & $\mathrm{y}=2,6151+0,1862 \mathrm{x}$ & 0,9336 & $* *$ \\
\hline Doente & $\mathrm{y}=-0,3094+0,3925 \mathrm{x}$ & 0,9844 & $*$ \\
\hline Doente + Ribavirina & $\mathrm{y}=2,2414+0,1783 \mathrm{x}$ & 0,9469 & \\
\hline
\end{tabular}

A significância estatística da regressão foi avaliada pelo teste $F$ e as equações assinaladas por $\left(^{*}\right)$ indicam significância estatística para $\mathrm{P}<0,05$, o sinal $\left({ }^{* *}\right)$ indica alta significância, nível de probabilidade $\mathrm{P}<0,01$.

A representação gráfica do aumento do valor de $\mathrm{W}$ com o passar do tempo utilizando-se valores médios foi próxima a uma reta, como pode-se observar na figura 7.

Os resultados das análises estatísticas deste método indireto foram equivalentes aos obtidos para o método direto, que envolve a contagem de protoplastos em cultivo ao microscópio óptico, apesar do primeiro considerar apenas os protoplastos viáveis.

Os valores dos intervalos de confiança para cada média aos níveis de $95 \%$ e $99 \%$ de probabilidade estão listados no Apêndice 3, juntamente com os valores da variância e desviopadrão dos experimento total.

Não se observou interação entre os tratamentos (presença do vírus e tratamento com ribavirina) aos níveis de $\mathrm{P}<0,05$ e $\mathrm{P}<0,01$ de probabilidade, sendo considerados independentes.

Quanto aos contrastes de médias, os únicos contrastes significativos ao nível de $\mathrm{P}<0,05$ foram do material sadio com o doente, e do material sadio com o doente tratado com ribavirina, como mostra a tabela 4 . 


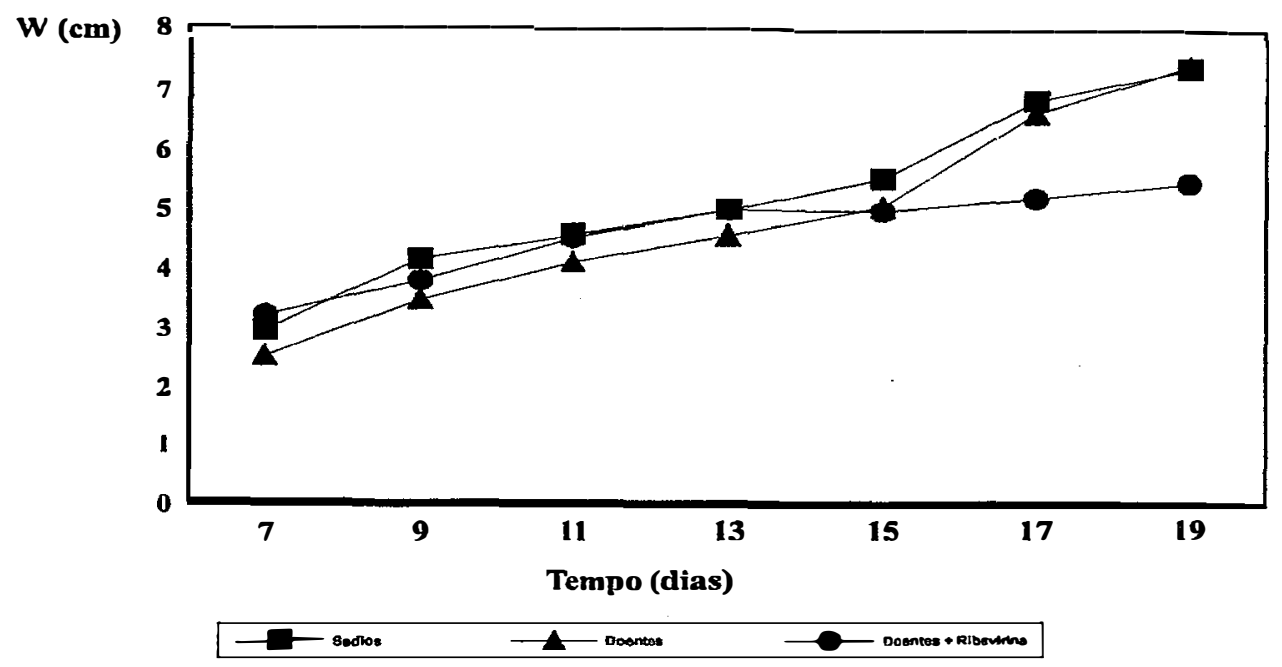

Figura 7 - Curvas de crescimento de protoplastos de mesófilo de Nicotiana tabacum sadios e infectados com VVCT e infectados e tratados com ribavirina em cultivo de suspensão, representado como medida do valor de $\mathrm{W}$.

Tabela 4 : Comparação dos contrastes de médias através do teste $\mathrm{F}$ para todos os tratamentos a nível de $95 \%$ de probabilidade.

\begin{tabular}{|c|c|}
\hline Contraste de Médias & Significância (P < 0,05) \\
\hline Sadio x Doente & $*$ \\
\hline Sadio x Sadio com Ribavirina & n.s. \\
\hline Sadio x Doente com Ribavirina & n.s. \\
\hline Doente x Sadio com Ribavirina & n.s. \\
\hline Doente x Doente com Ribavirina & n.s. \\
\hline Sadio com Ribavirina x Doente com Ribavirina & \\
\hline
\end{tabular}

Os contrastes, comparados através do teste $\mathrm{F}$, marcados com $\left(^{*}\right)$ indicam significância estatística ao nível de probabilidade mencionado, enquanto que os contrastes assinalados com (n.s.) indicam inexistência de significância estatística para o mesmo nivel de probabilidade. 
Comparando-se com o controle sadio os contrastes entre os materiais doente e doente tratado com ribavirina, apresentaram diferenças estatisticamente significativas, sendo que ao nível de $99 \%$ de probabilidade todos os contrastes testados foram estatisticamente idênticos. Assim, tanto o efeito da presença do VVCT quanto do tratamento com ribavirina não alteraram o crescimento dos protoplastos quando comparados com o material sadio a este nível de probabilidade.

Ao nível de $95 \%$ de probabilidade, a presença do VVCT e o tratamento com ribavirina afetaram o padrão de crescimento dos protoplastos quando comparados com o material sadio, sendo que a cada um correspondeu ao padrão de crescimento representado pela respectiva equação de regressão.

Graficamente em forma de regressão linear, os efeitos dos tratamentos testados e significantes estatisticamente podem ser vistos na figura 8 .



Figura 8 - Curvas de crescimento de protoplastos de mesófilo de Nicotiana tabacum sadios, infectados com VVCT e infectados e tratados com ribavirina em cultivo de suspensão, representado como regressão linear das medidas do valor de $\mathrm{W}$ 


\subsection{Reutilização de Enzima Líticas na Obtenção de Protoplastos}

A obtenção de protoplastos de mesófilo de fumo a partir de enzima líticas anteriormente usadas para o mesmo propósito não provocou alteração na cinética de crescimento dos mesmos em cultivo de suspensão.

Não se observou diferença estatística significativa entre a enzima reutilizada por uma vez ( $R$ ) e a utilizada pela primeira vez (referida como não-reutilizada - nR) em nenhum dos métodos utilizados, como se pode perceber pelas tabelas 5 e 6 e pelas figuras 9 e 10 .

Tabela 5 : Comparação entre parâmetros estatísticos para material obtido a partir de enzima reutilizada e de não-reutilizada, realizada com base no método direto (contagem com Câmara de Neubauer).

\begin{tabular}{|c|c|c|}
\hline \multicolumn{2}{|c|}{ Enzima reutilizada (R) } & Enzima não-reutilizada (nR) \\
\hline eq. de regressão & $\log y=-5,1233+0,2536 x$ & $\log \mathbf{y}=-5,4559+0,3099 x$ \\
\hline coef. correl. (r) & 0,9972 & 0,9698 \\
\hline $\mathbf{s}$ & 2,0730 & 1,8740 \\
\hline $\mathbf{s}^{2}$ & 4,2970 & 3,5119 \\
\hline $\mathbf{n}$ & $7 \times 11$ & $7 \times 11$ \\
\hline sign. regressão & $*$ & $*$ \\
\hline sign. (r) $\mathbf{x}(\mathbf{n r})$ & n.s. & n.s. \\
\hline
\end{tabular}


$\log . \mathrm{n}^{0}$ prot. $(.10 \mathrm{E}-5) / \mathrm{mL}$

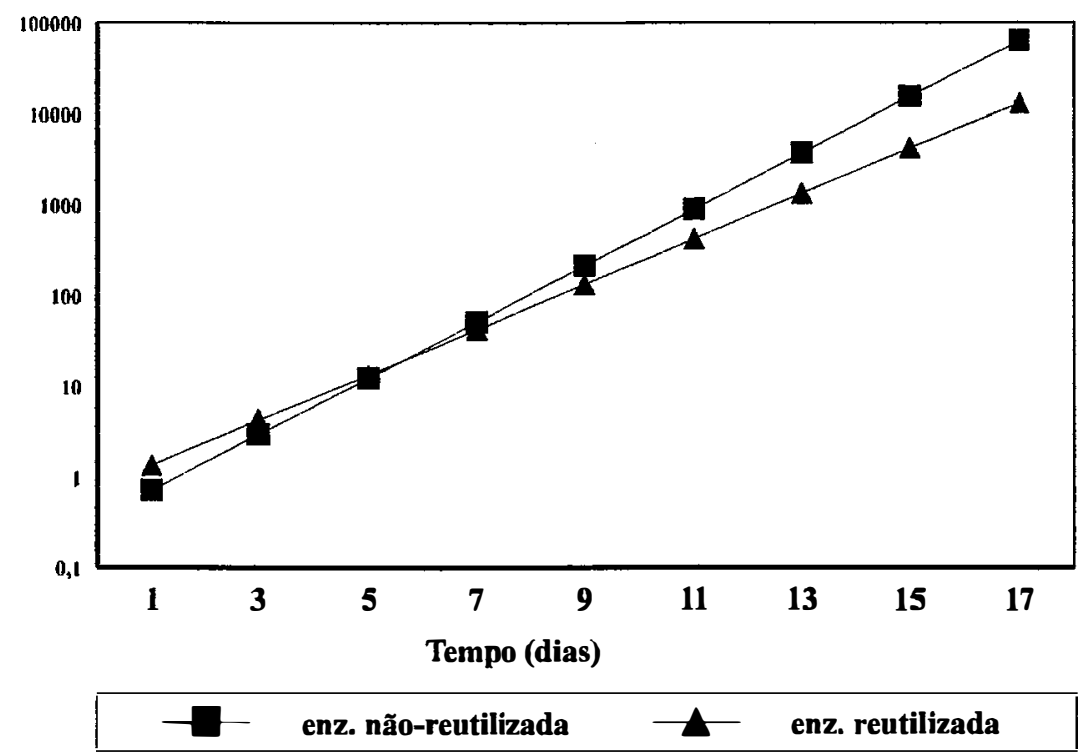

Figura 9 Comparação gráfica entre as equações de regressão linear com transformação logarítmica para material obtido a partir de enzima reutilizada e não-reutilizada, realizada com base no método direto (contagem com Câmara de Neubauer).

Tabela 6 : Comparação entre parâmetros estatísticos para material obtido a partir de enzima reutilizada e não-reutilizada, realizada com base no método indireto (medida do valor de W ).

\begin{tabular}{|c|c|c|}
\hline & Enzima reutilizada (R) & Enzima não-reutilizada (nR) \\
\hline eq. de regressão & $\mathrm{y}=1,246+0,254 \mathrm{x}$ & $\mathrm{y}=0,617+0,350 \mathrm{x}$ \\
\hline coef. correl. (r) & 0,911014763 & 0,985233125 \\
\hline $\mathbf{s}$ & 1,486659759 & 1,536020034 \\
\hline $\mathbf{s}^{2}$ & 2,210157238 & 2,35935700 \\
\hline $\mathbf{n}$ & $7 \times 7$ & $7 \times 7$ \\
\hline sign. regressão & $*$ & n.s. \\
\hline sign. (r) $\mathbf{x}(\mathbf{n r})$ & n.s. & $*$ \\
\hline
\end{tabular}




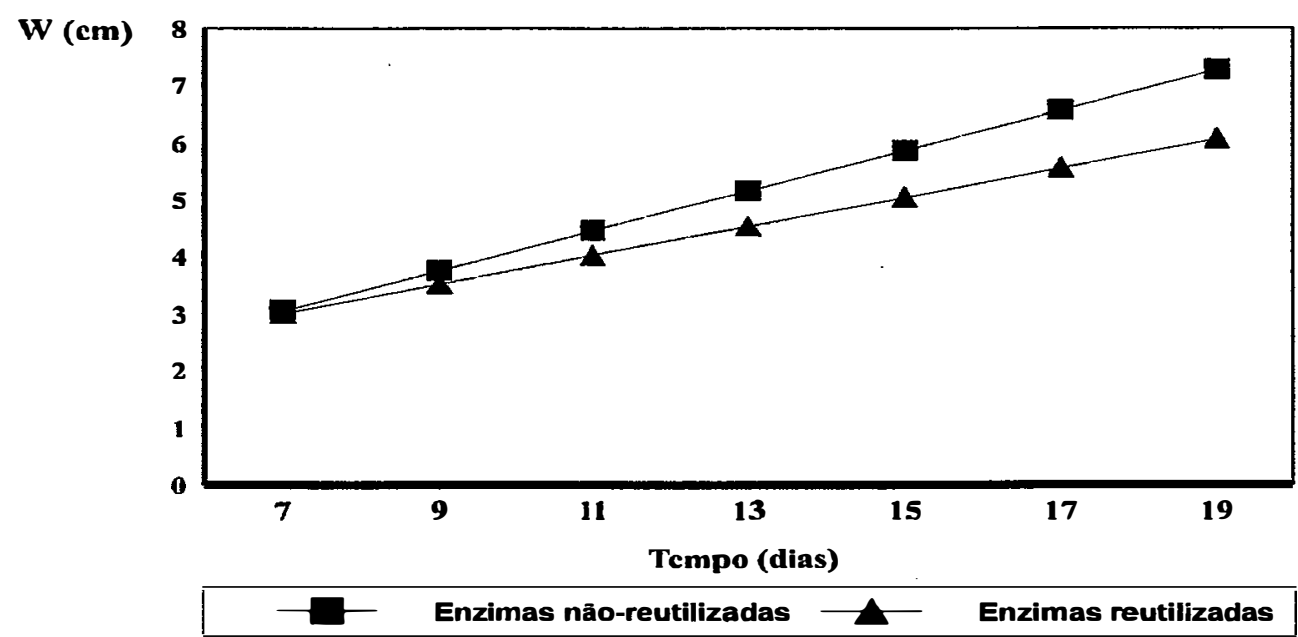

Figura 10 : Comparação gráfica entre as equações de regressão logarítmica para material obtido a partir de enzima reutilizada e não-reutilizada, realizada com base no método indireto (medida do valor $\mathrm{W}$ ).

\subsection{Perfis eletroforéticos de Peroxidases, Shiquimato Desidrogenases e Amilases}

\subsubsection{Peroxidases}

O material proveniente de tomate doente e doente tratado com ribavirina (figura 1le 12) e o material de fumo doente (figura 11) possuem uma banda de atividade de isoperoxidases de peso molecular de $64 \mathrm{kD}$, sendo que esta mesma banda se apresenta como uma região difusa no material de fumo doente tratado com ribavirina (figura 11) e de tomate sadio (figura 12). Uma banda com o mesmo peso molecular ocorre para os três tratamentos em petúnia (figura 12).

O material doente de fumo apresenta o mesmo padrão de bandas, tanto para o material tratado com ribavirina quanto para o material apenas inoculado com o VVCT. O mesmo pode ser observado para o material proveniente de tomate com os mesmos tratamentos.

0 tomate doente e tratado com ribavirina apresentou 3 bandas nítidas de ação da peroxidase, de $32 \mathrm{kD}$ e $15,7 \mathrm{kD}$; além daquela de peso molecular mais elevado anteriormente mencionada (figura 11). Estas bandas formam uma zona de coloração mais intensa no gel, sendo que na figura 12 pode-se visualizar uma banda intermediária ( $24 \mathrm{kD})$. 
As proteínas provenientes do fumo, de folhas inoculadas com o VVCT, apresentaram uma banda de $64 \mathrm{kD}$, indicativa da atividade de peroxidases, tanto para o material só inoculado quanto para o material inoculado e tratado com ribavirina, sendo que neste último apresenta-se como uma zona difusa de coloração no gel (figura 11).

Além da anteriormente mencionada, o fumo apresentou bandas nítidas e distintas e de peso molecular calculado igual a $16,5 \mathrm{kD}$ (figura 11 ), coincidindo com as observadas e petúnia (figura 12).

A petúnia apresentou padrão semelhante de bandas de atividade das isoperoxidases para todos os tratamentos, ou seja, sadio (S), infectado com VVCT (D) e doente tratado com ribavirina (R), estando presente uma banda mais nítida de $64 \mathrm{kD}$ que igualmente ocorreu nas outras hospedeiras. Quando comparado ao das outras hospedeiras, ambas sistêmicas, observa-se que o perfil de isoperoxidases da petúnia, hospedeira hipersensível, apresenta bandas mais nítidas e em maior quantidade, como visto na figura 12 . Os pesos moleculares calculados para as três isoformas foram $36 \mathrm{kD}, 27,1 \mathrm{kD}, 23,8 \mathrm{kD}$ e $16,5 \mathrm{kD}$, em ordem decrescente. 


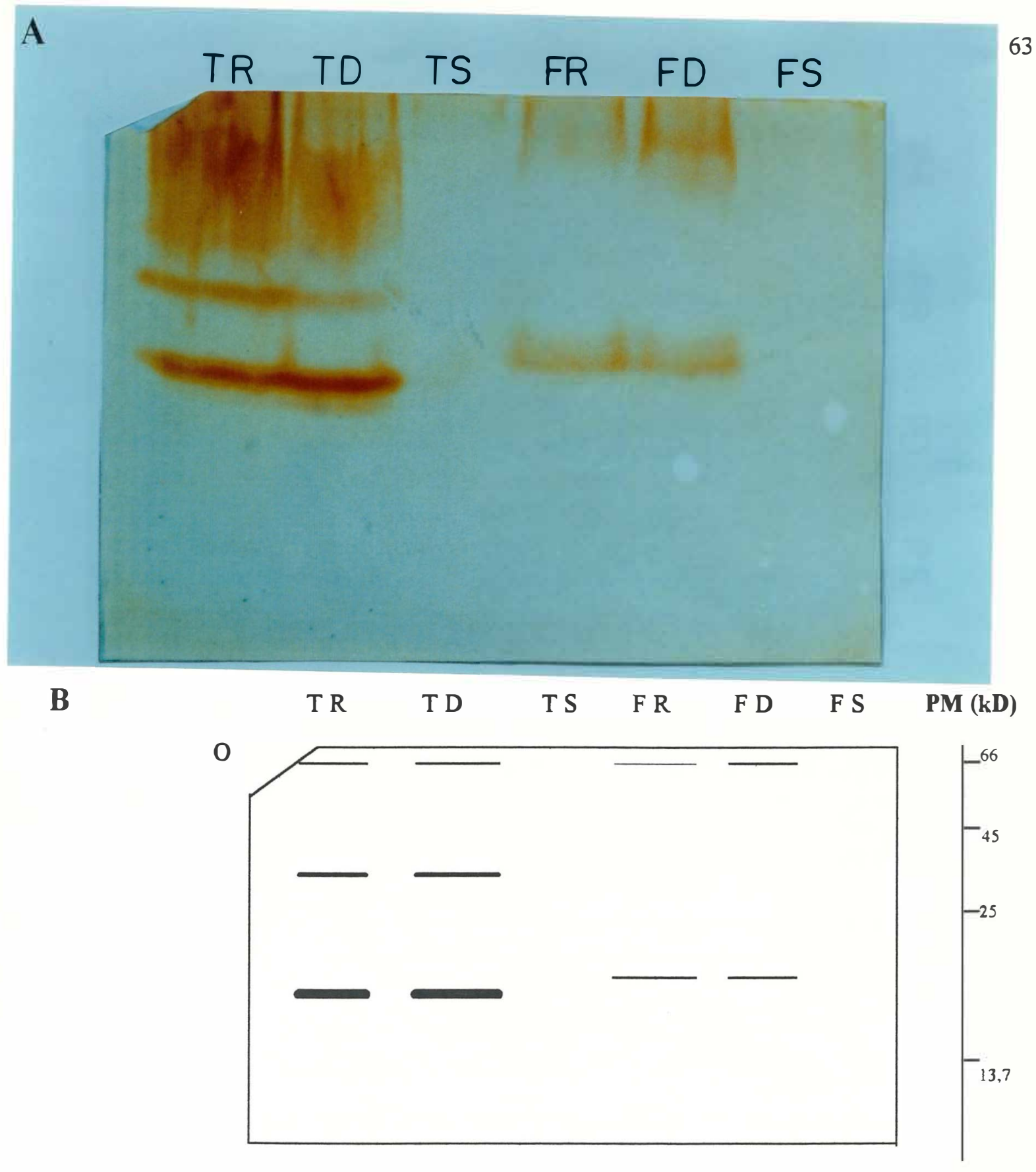

Figura 11 - (A) Perfis eletroforéticos em gel de poliacrilamida das isoperoxidases solúveis totais nos extratos de folha de tomate (Lycopersicon esculentum Mill.) e fumo (Nicotiana tabacum L.) e sua representação esquemática (B). TS - tomate sadio, TD - tomate infectado com VVCT, TR - tomate infectado e tratado com ribavirina, FS - fumo sadio, FD - fumo infectado com VVCT e FR - fumo infectado e tratado com ribavirina. O PM referencial está indicado ao lado. $\mathbf{O}$ indica a origem da eletroforese. 

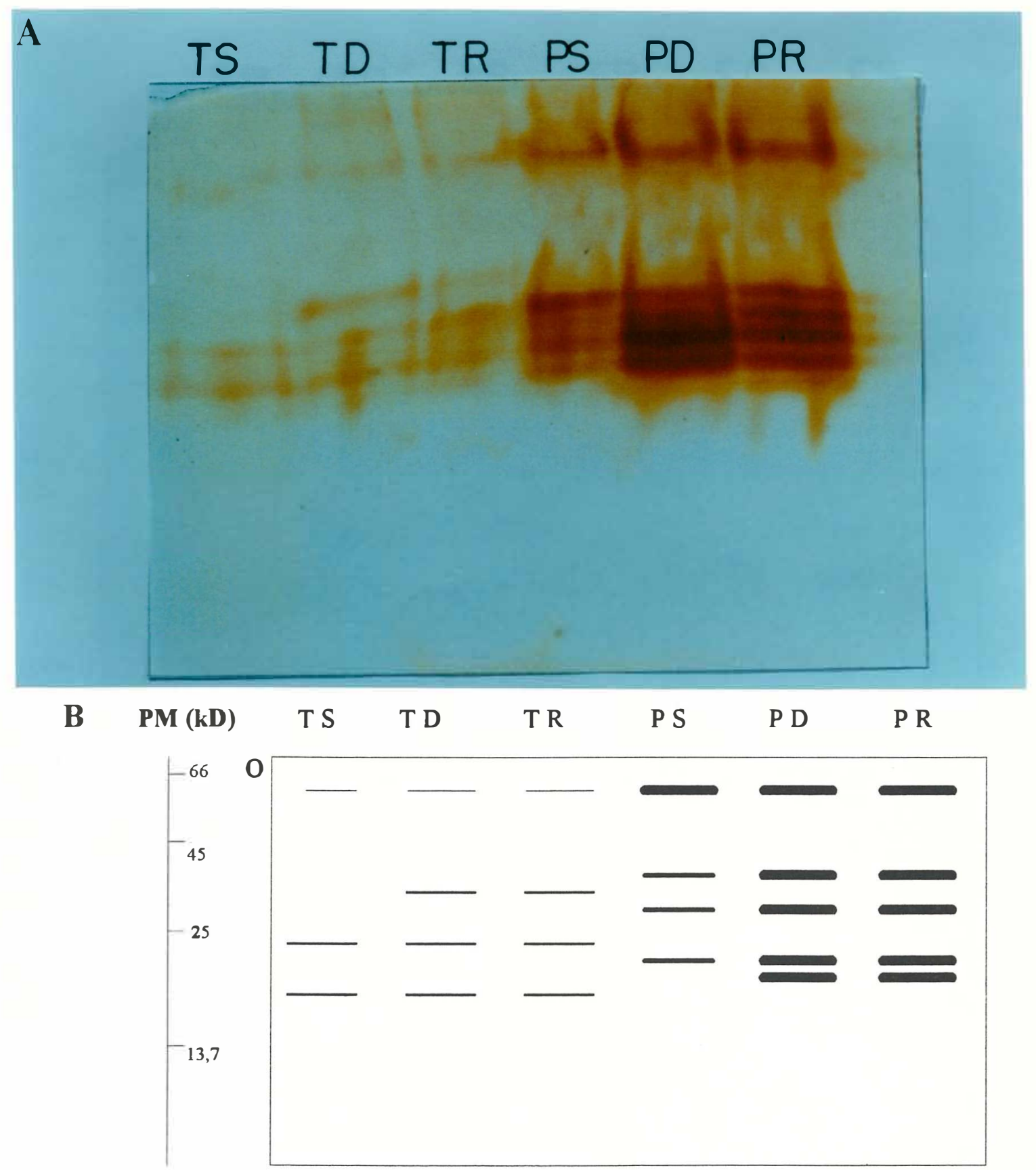

Figura 12 - (A) Perfis eletroforéticos em gel de poliacrilamida das isoperoxidases solúveis totais nos extratos de folha de tomate (Lycopersicon esculentum Mill.) e petúnia (Petunia hybrida Vilm.) e sua representação esquemática ( B ). TS - tomate sadio, TD - tomate infectado com VVCT, TR - tomate infectado e tratado com ribavirina, PS - petúnia sadia, PD - petúnia infectada com VVCT, PR - petúnia infectada com VVCT e tratada com ribavirina. O PM referencial está indicado ao lado. $\mathbf{O}$ indica a origem da eletroforese. 


\subsubsection{Shiquimato Desidrogenases}

As proteinas extraídas de material sadio de fumo e tomate não apresentaram nenhuma banda indicativa de atividade da shiquimato desidrogenase quando corridas em mini-géis $(10 \mathrm{~cm}$ de comprimento). No entanto, quando corridas em géis normais ( $15 \mathrm{~cm}$ de comprimento), o material proveniente de petúnia apresentou uma zona indistints, indicando provavelmente 3 ou 4 bandas unidas, uma banda mais distinta, com peso molecular mais elevado e outra com menor peso molecular (figura 15).

A coloração nos géis maiores foi negativa, ou seja, as bandas claras de atividade da enzima e o fundo com coloração arroxeada. Esta inversão de coloração foi observada todas as vezes em que foi usado um gel maior, mesmo quando as placas de vidro usadas foram outras (figura 15). Não se encontrou explicação satisfatória para este fato.

O perfil de atividade da shiquimato desidrogenase em petúnia apresentou uma banda no material sadio (PS), quando comparado com o doente e o doente tratado com ribavirina. Esta banda observada foi de alto peso molecular $(45 \mathrm{kD})$ e esteve distinta nos géis de tamanho pequeno $(10 \mathrm{~cm})$, como pode-se observar na figura 13 , mas não esteve presente no material com coloração negativa (figura 15).

Nos perfis de atividade desta enzima proveniente de proteínas de fumo, não observou-se nenhuma banda indicando isoformas ativas da shiquimato desidrogenase, tanto nos mini-géis quanto em géis normais.

Pôde-se observar, três bandas de atividade das isoshiquimato desidrogenases em tomate sadio, nos géis maiores (não apresentado). Sob condições de mini-gel, observa-se uma banda nítida e inteira para o material tratado com ribavirina e uma banda interrompida para o material sadio, mas como esta não se repetiu em nenhuma outra corrida, foi considerada como artefato, causado pelo extravasamento de material de uma canaleta para a outra, como observa-se na figura 14.

Não se observou, nas condições deste trabalho, associações da presença do VVCT e do tratamento com ribavirina com alterações nos perfis eletroforéticos de isoshiquimato desidrogenases para os hospedeiros utilizados. 


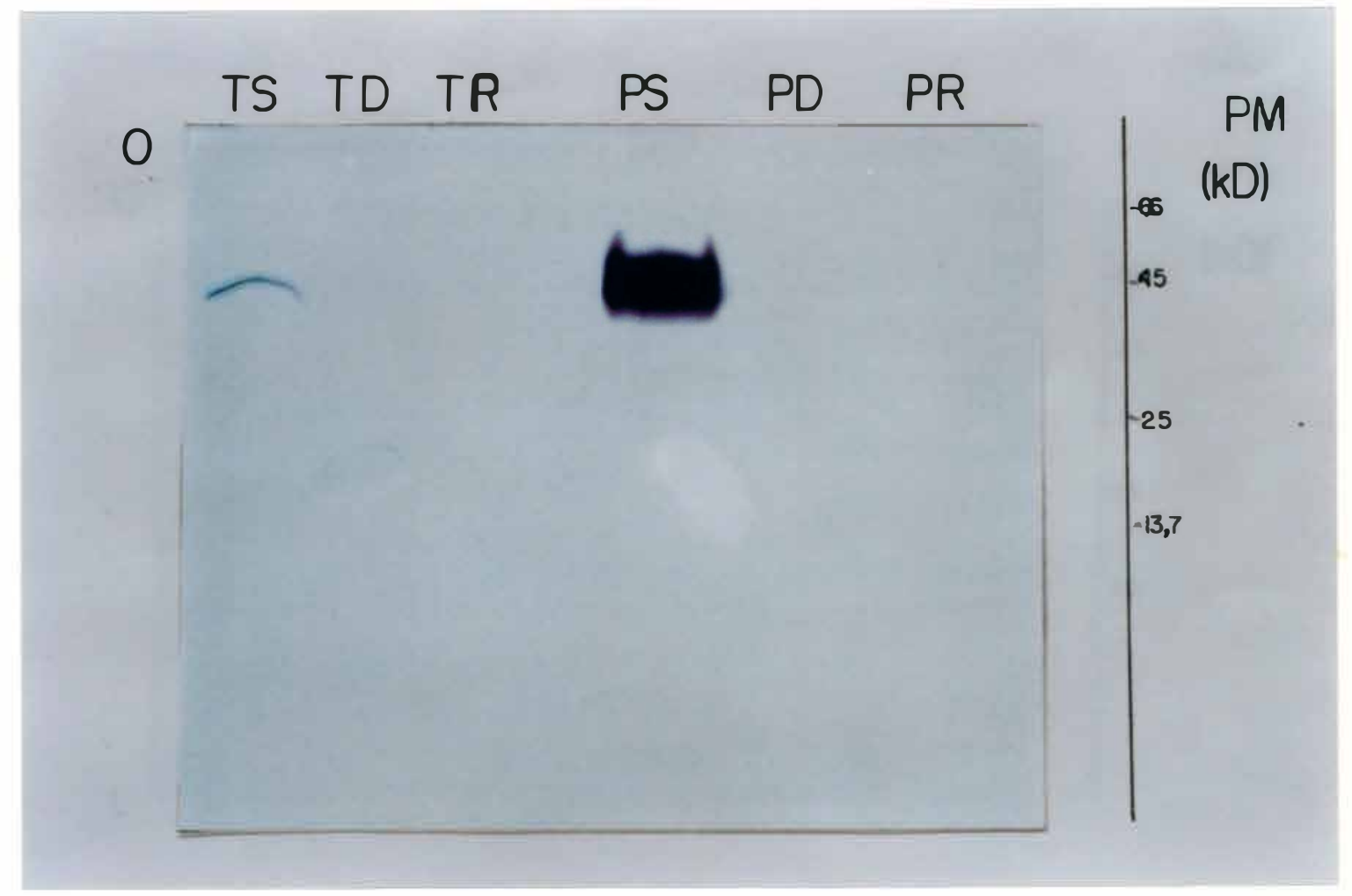

Figura 13 - Perfil eletroforético em gel de poliacrilamida de isoshiquimato desidrogenase solúveis totais nos extratos de folha de tomate (Lycopersicon esculentum Mill.) e petúnia (Petunia hybrida Vilm.).TS - tomate sadio, TD - tomate infectado com VVCT, TR - tomate infectado e tratado com ribavirina, PS - petúnia sadia, PD - petúnia doente e PR - petúnia doente tratada com ribavirina. O PM referencial está indicado ao lado. $\mathbf{O}$ indica a origem da eletroforese. 


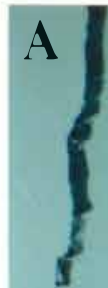

TS TD TR FS FD FR

B

$\begin{array}{llllll}\text { TS T D } & \text { TR } & \text { F S } & \text { F D } & \text { F R }\end{array}$

PM (kD)
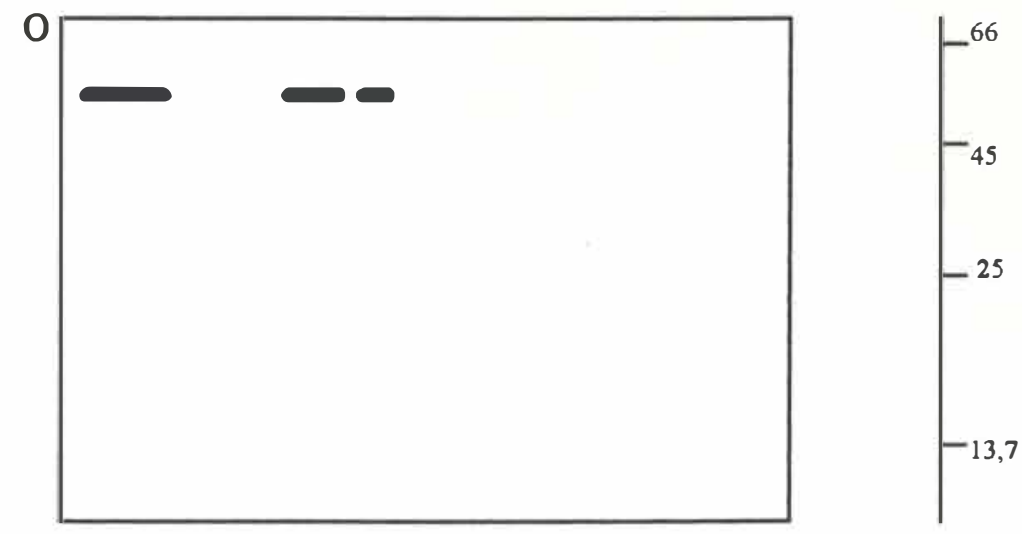

Figura 14 -(A) Perfil eletroforético em gel de poliacrilamida de isoshiquimato desidrogenases solúveis totais nos extratos de folha de tomate (Lycopersicon esculentum Mill.) e fumo (Nicotiana tabacum L.) e sua representação esquemática (B). TS - tomate sadio, TD - t tomate infectado com VVCT, TR - tomate infectado e tratado com ribavirina, FS - fumo sadio, FD - fumo infectado com VVCT e FR - fumo infectado e tratado com ribavirina. O PM referencial está indicado ao lado. $\mathbf{O}$ indica a origem da eletroforese. 


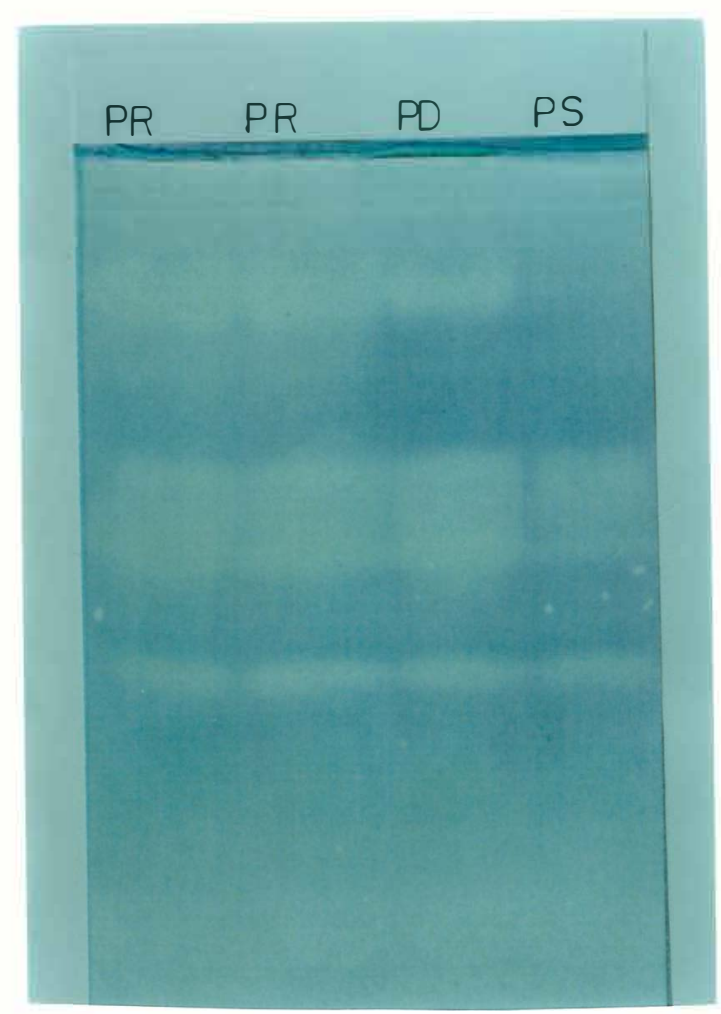

B

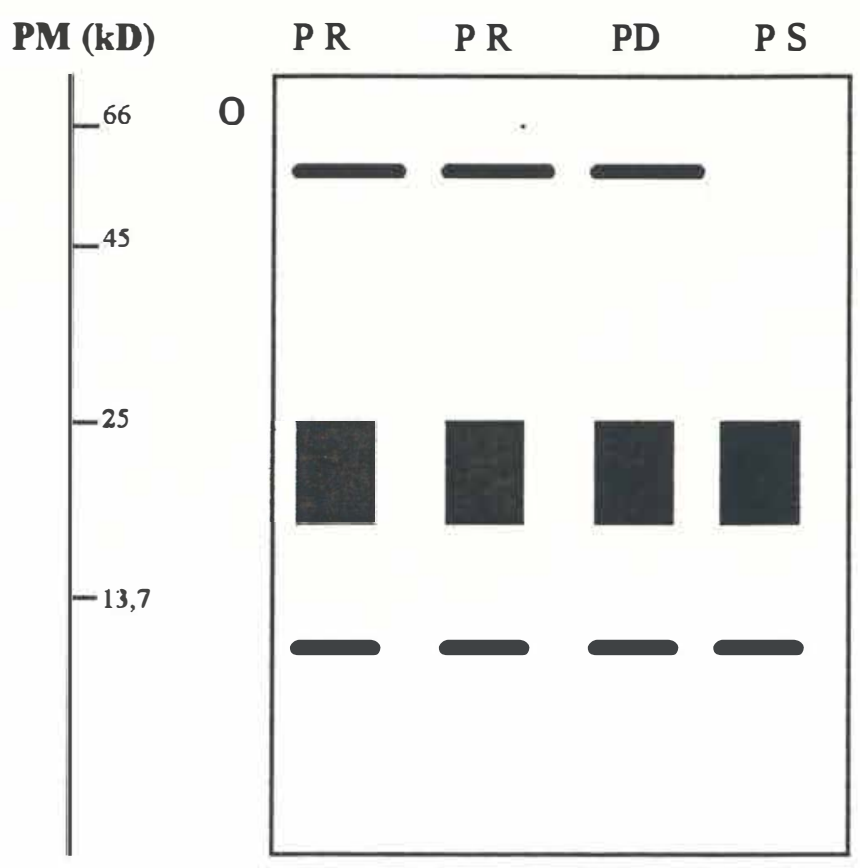

Figura 15 - (A) Perfil eletroforético em gel de poliacrilamida de isoshiquimato desidrogenases solúveis totais nos extratos de folha de petúnia (Petunia hybrida Vilm.) e sua representação esquemática (B). PS - petúnia sadia, PD - petúnia infectada com VVCT, PR - petúnia infectada com VVCT e tratada com ribavirina. O PM referencial está indicado ao lado. $\mathbf{O}$ indica a origem da eletroforese. 


\subsubsection{Amilases}

Os perfis eletroforéticos das isoamilases presentes nos extratos cru de folha de fumo (Nicotiana tabacum L.), tomate (Lycopersicon esculentum Mill.) e petúnia (Petunia hybrida Vilm.) apresentaram-se semelhantes nos ensaios realizados.

Mostraram apenas a presença de uma banda de peso molecular calculado de $63,1 \mathrm{kD}$ uniforme e presente em todos os ensaios, tanto em géis de $15 \mathrm{~cm}$ de comprimento (não apresentados) quanto nos mini-géis de $10 \mathrm{~cm}$ de comprimento (figuras 16 e 17).

No entanto, pôde-se observar diferenças quanto à intensidade da banda no caso de fumo e da petúnia tratados com ribavirina, como mostram as figuras 16 e 17. Mas como esta diferença foi apenas visual e não foi investigada quantitativamente, conclusões não podem ser tiradas a partir desta observação.

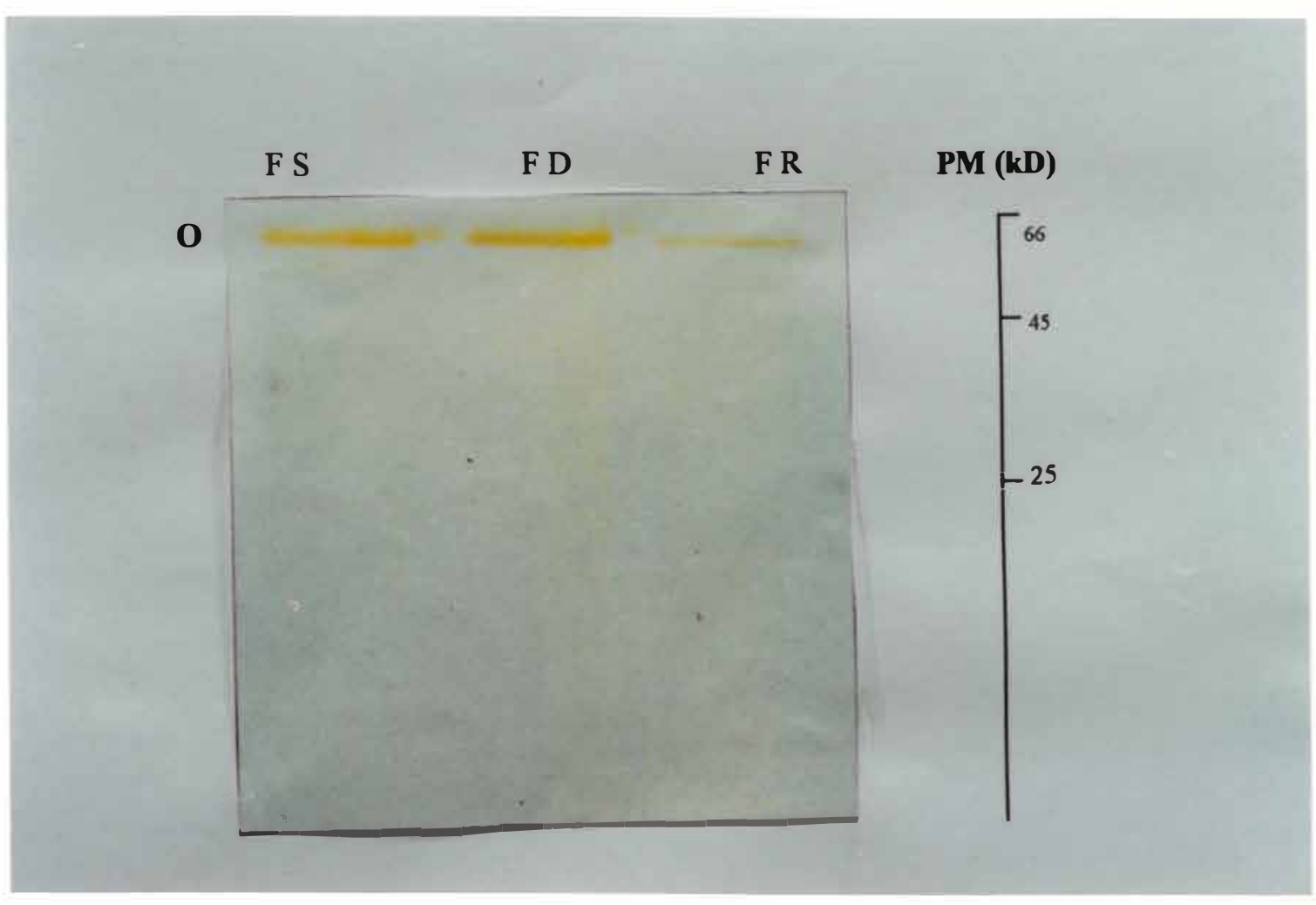

Figura 16- Perfil eletroforético em gel de poliacrilamida e amido de isoamilases solúveis totais nos extratos de folha de fumo (Nicotiana tabacum L.). FS - fumo sadio, FD - fumo doente e FR - fumo doente tratado com ribavirina. O PM referencial está indicado ao lado. $\mathbf{O}$ indica a origem da eletroforese. 


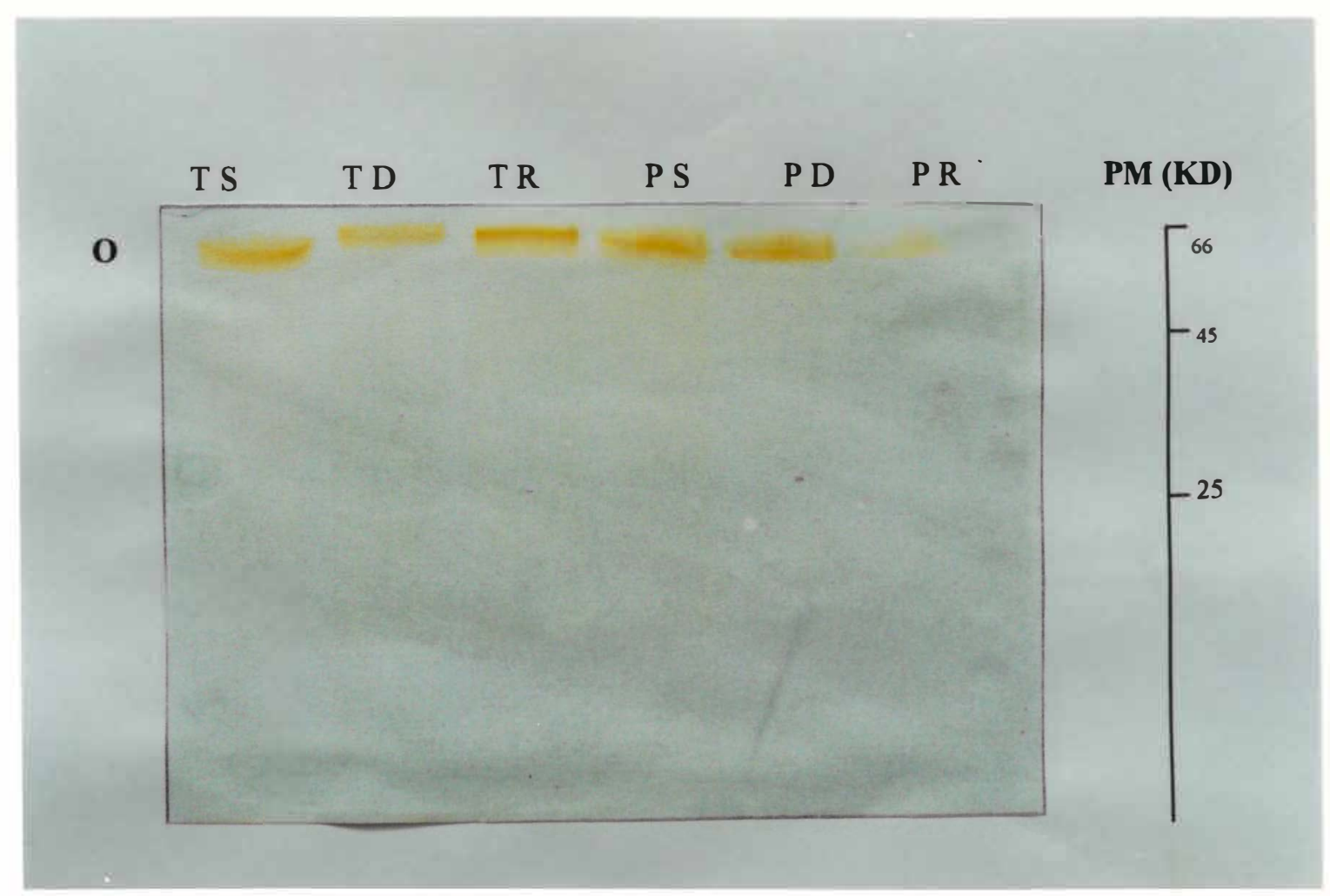

Figura 17-Perfil eletroforético em gel de poliacrilamida e amido de isoamilases solúveis totais nos extratos de folha de petúnia (Petunia hybrida Vilm.) e tomate (Lycopersicon esculentum Mill.) . PS - petúnia sadia, PD - petúnia infectada com VVCT, PR - petúnia infectada com VVCT e tratada com ribavirina, TS - tomate sadio, TD - tomate infectado com VVCT, TR - tomate infectado e tratado com ribavirina, O PM referencial está indicado ao lado. $\mathbf{O}$ indica a origem da eletroforese.

\subsection{Atividade de Peoxidases, Shiquimato Desidrogenases e Amilases nas Membranas de Nitrocelulose}

\subsubsection{Peroxidases}

Em folhas de petúnia, com reação de hipersensibilidade ao VVCT, impressas observou-se que os locais em que ocorrem lesões necróticas a atividade das peroxidases foi muito maior, inclusive sendo notada uma coloração de tonalidade diferente, tendendo mais ao cinza. Observase também que pontos cloróticos intensos também apresentam coloração mais forte (figura 18). 
Os sintomas sistêmicos observados em folhas de fumo, aparecem como zonas concêntricas de coloração mais escura nas bordas e mais clara no centro nos "blots" realizados. Algumas zonas de círculos concêntricos na membrana correspondem às nervuras da folha. 0 tecido verde sem sintomas aparece fracamente corado (figura 20).

Em tomate, sistemicamente infectado pelo VVCT, nota-se que a região central dos folíolos foi intensamente corada, mas permaneceu em sua tonalidade original, não chegando ao acinzentado observado em regiões necróticas das folhas de petúnia. Pode-se visualizar uma tendência a seguir a nervura central dos folíolos das zonas de cor mais intensa (figura 22).

As impressões de folhas sadias apresentaram apenas uma coloração semelhante à de fundo presente no material doente, sendo que em partes mais suculentas a transferência de proteínas para a membrana foi mais intensa, aumentando a intensidade da coloração de fundo (figuras 19, 21 e 23). 
$A$

$B$

Figura 18 - "Tissue blot" em membrana de nitrocelulose (B) de folha de petúnia (Petunia hybrida Vilm.) infectada com VVCT (A) para isoperoxidases. A posição da impressão na membrana é invertida. As lesões locais e as regiões correspondentes de maior atividade das isoperoxidases encontram-se indicadas por $\rightarrow$.

A

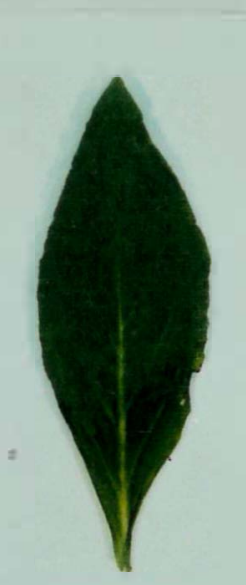

B

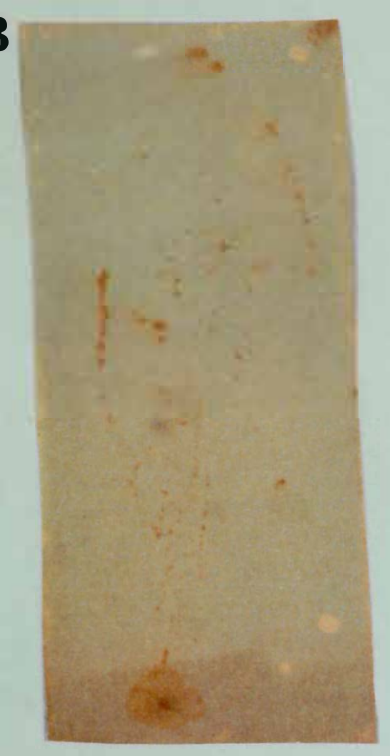

Figura 19 - "Tissue blot" em membrana de nitrocelulose (B) de folha sadia de petúnia (Petunia hybrida Vilm.) (A) corado para isoperoxidases. A posição da impressão na membrana é invertida. 


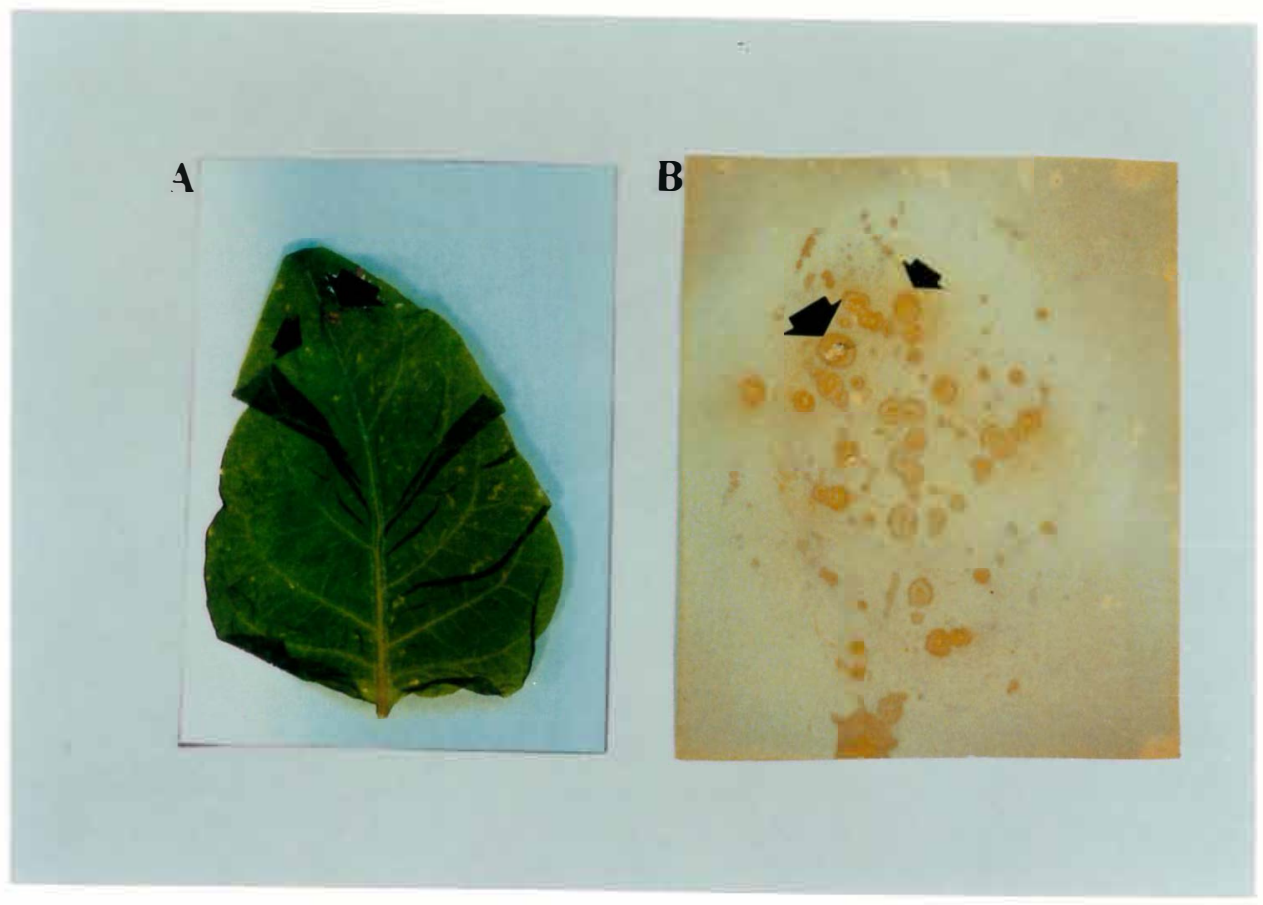

Figura 20 - "Tissue blot" em membrana de nitrocelulose (B) de folha de fumo (Nicotiana tabacum L.) infectada com VVCT (A) para isoperoxidases. A posição da impressão na membrana é invertida. Os locais indicados por $\rightarrow$ denotam lesões sistêmicas mais intensa e regiões correspondentes de atividade mais intensa de isoperoxidases.

A
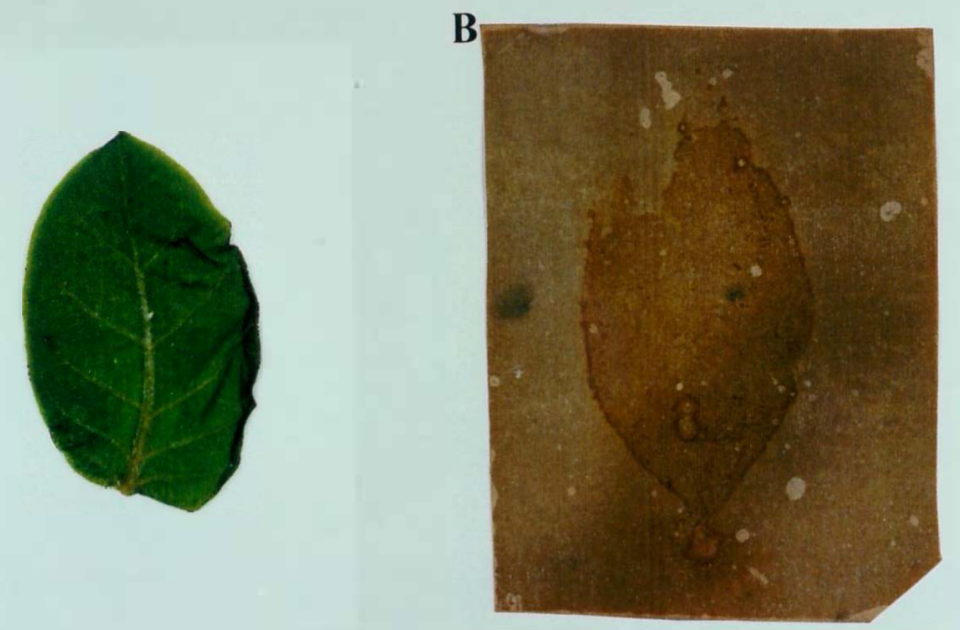

Figura 21 - "Tissue blot" em membrana de nitrocelulose (B) de folha sadia de fumo (Nicotiana tabacum L.) (A) para isoperoxidases. A posição da impressão na membrana é invertida. 

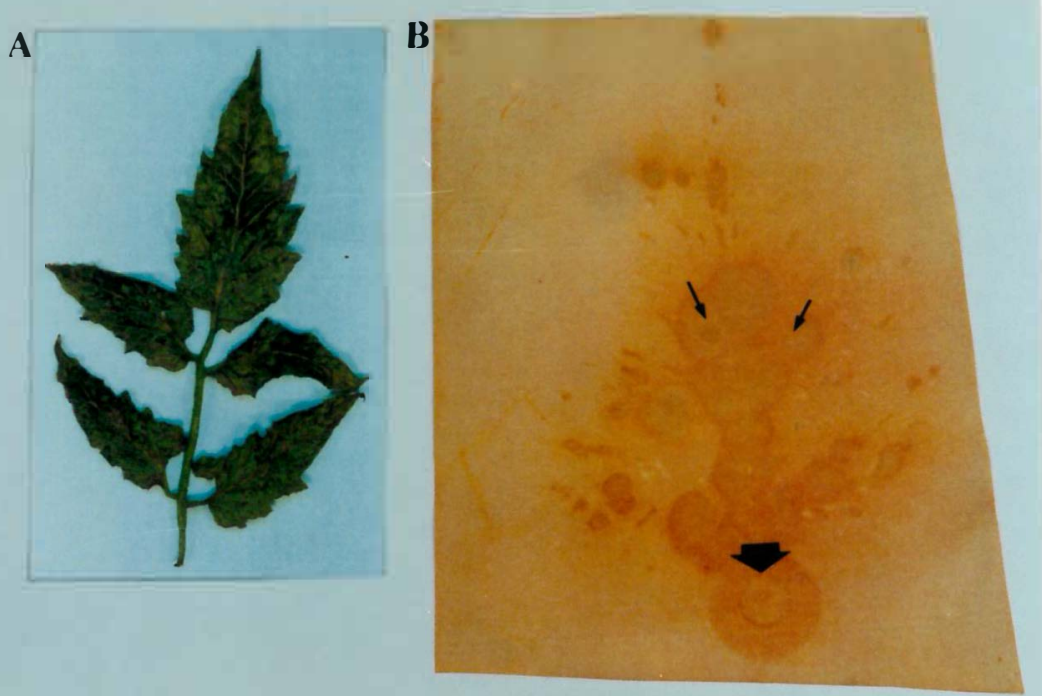

Figura 22- "Tissue blot" em membrana de nitrocelulose (B) de folha de tomate (Lycopersicon esculentum Mill.) infectada com VVCT (A) para isoperoxidases. A posição da impressão na membrana é invertida. As regiões de atividade mais intensa das isoperoxidases estão indicadas por $\rightarrow$.

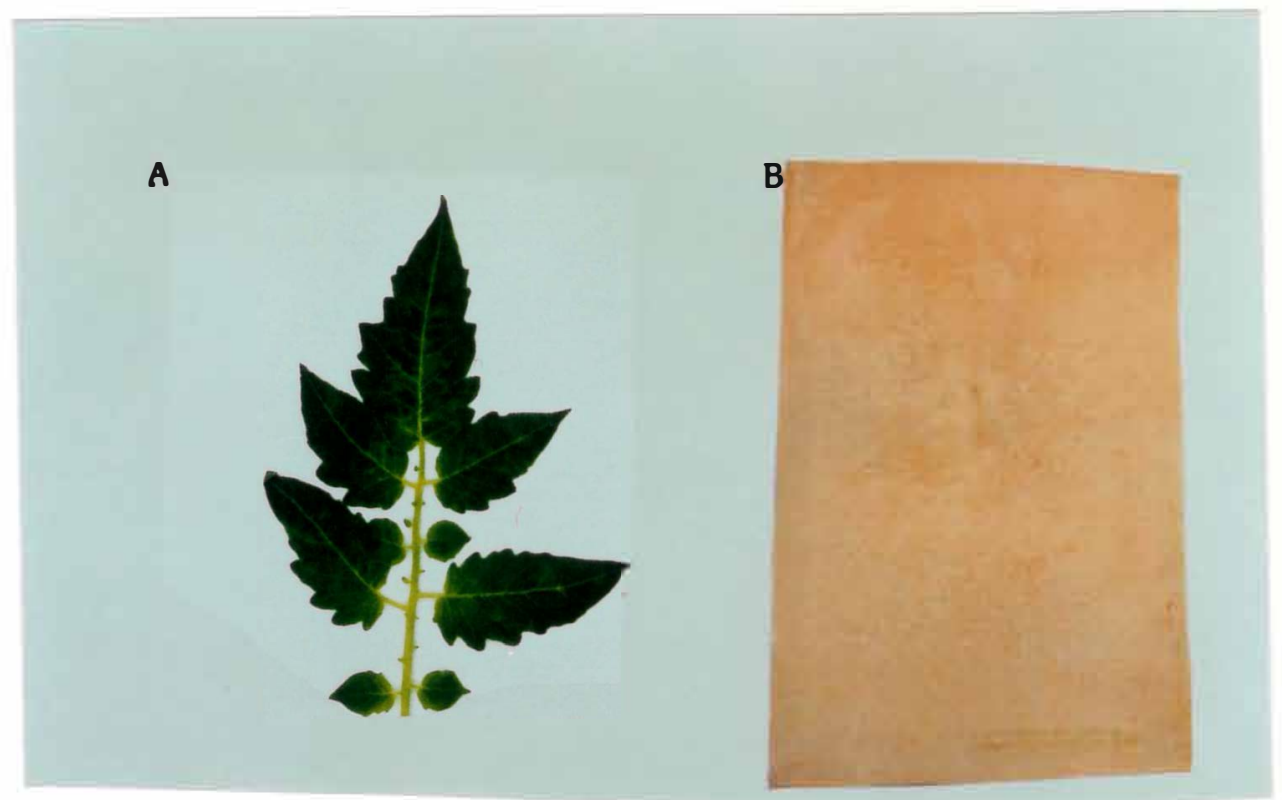

Figura 23- "Tissue blot" em membrana de nitrocelulose $(\mathbf{B})$ de folha sadia de tomate

(Lycopersicon esculentum Mill.) (A) para isoperoxidases. A posição da impressão na membrana é invertida 


\subsubsection{Shiquimato Desidrogenase}

Este material apresentou uma relativa dificuldade em provocar coloração adequada em membranas de nitrocelulose, sendo que um tempo de incubação maior (12 h.), no escuro, foi necessário, o que acabou por levar a um aumento na reação de fundo, dificultando a visualização.

No entanto, em folhas de petúnia pode-se visualizar zonas de coloração mais escuras, mas estas não correspondem aos sintomas necróticos ou cloróticos mais intensos (figura 24).

Em folhas de fumo e tomate não foi possível a observação de quaisquer diferenças provocadas por sintomas da presença do VVCT, isto foi devido à coloração muito intensa do fundo, possivelmente provocada pelo período de incubação longo. 

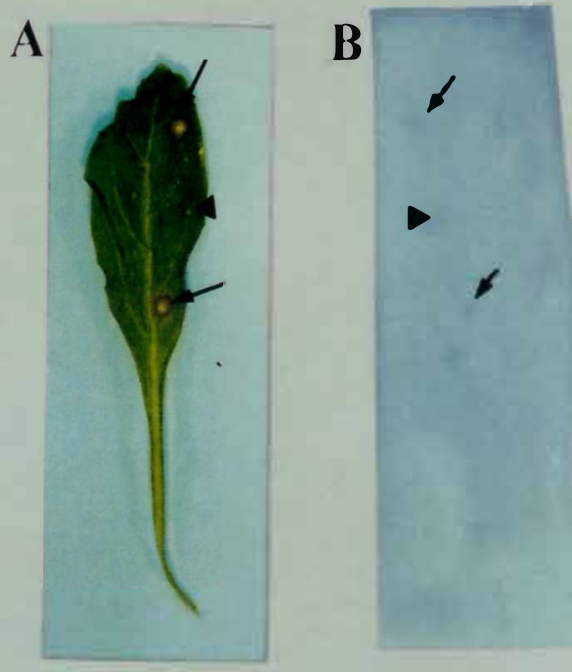

Figura 24 - "Tissue blot" em membrana de nitrocelulose (B) de follha de petúnia (Petunia hybrida Vilm.) infectada com VVCT (A) para isoshiquimato desidrogenases. A posição da impressão na membrana é invertida. As lesões locais e regiões correspondentes na membrana encontram-se indicadas por $\rightarrow$.

A

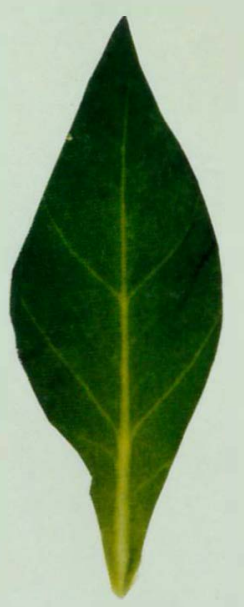

B

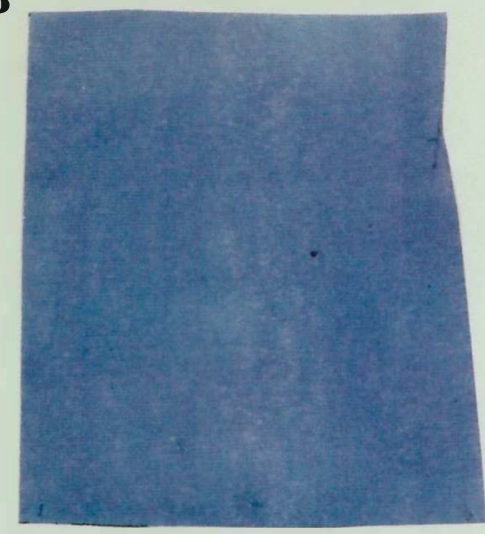

Figura 25 - "Tissue blot" em membrana de nitrocelulose (B) de folha sadia de petúnia (Petunia hybrida Vilm.) (A) para isoformas de shiquimato desidrogenase. A posição da impressão na membrana é invertida. 


\subsubsection{Amilase}

Semelhantemente ao que ocorre com géis de poliacrilamida contendo amido solúvel, mas membranas de nitrocelulose em que a atividade destas isoenzimas foi detectada a coloração é negativa, ou seja, as zonas mais clara indicam intensa atividade enzimática, enquanto que naquelas em que o azul é intenso a atividade é fraca.

No caso das isoformas da amilase, utilizando-se o procedimento proposto por WAGIH (1992), o que se pode notar foi que embora o contomo da folha impressa não tenha ficado muito nítido, não pode afirmar que existam áreas em que a atividade desta enzima é mais intensa. As regiões em que a coloração azul parece ser mais forte não correspondem a sintomas intensos de clorose ou necrose (figura 26)

A

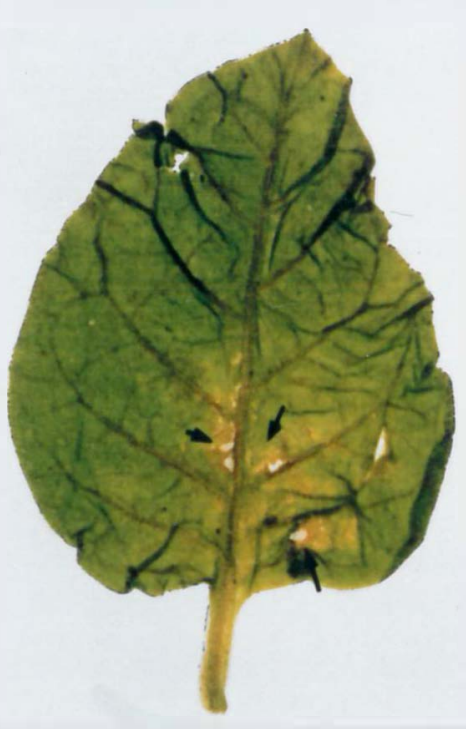

B

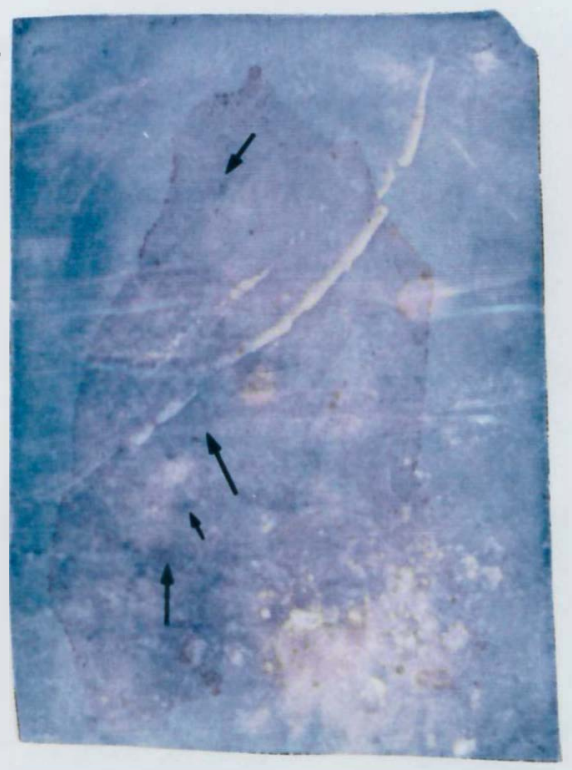

Figura 26- "Tissue blot" em membrana de nitrocelulose de folha de fumo (Nicotiana tabacum L.) para isoamilases, reveladas através do procedimento proposto por WAGIH (1992). A posição da impressão na membrana é invertida. As zonas de coloração mais intensa estão indicadas por $\rightarrow$ 
Com algumas alterações na metodologia proposta por VALLEJOS (1983), obteve-se formas mais nítidas na impressão sobre a membrana de nitrocelulose, mais ainda não possibilitou nenhuma associação entre os sintomas exibidos pelo material vegetal e a impressão correspondente embora possa observar-se zonas de coloração azul mais intensa na membrana, como pode-se notar na figura 27.

A

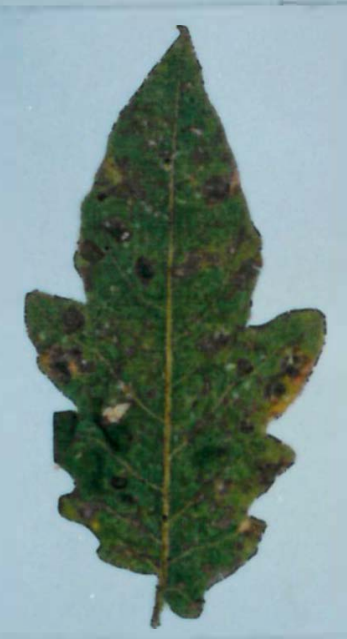

B

Figura 27- "Tissue blot" em membrana de nitrocelulose de folha de tomate (Lycopersicon esculentum Mill.) para isoamilases, reveladas através do procedimento proposto por VALLEJOS (1983). A posição da impressão na membrana é invertida. Os pontos de coloração azul mais intenso na membrana $(\rightarrow)$ indicam menor atividade das isoformas de amilase. 


\section{DISCUSSÃo}

5.1 Efeito da presença do VVCT e de Ribavirina sobre a cinética de crescimento de protoplastos em suspensão in vitro

\subsubsection{Métodos Indiretos}

\subsubsection{Densidade Óptica}

Não foi possível observar nenhuma correlação entre a densidade óptica do cultivo, medida a $\lambda=490 \mathrm{~nm}$, e o aumento de produção de biomassa, embora este procedimento já esteja bem estabelecido e seja eficiente em muitos outros casos semelhantes (PIRT, 1975; NOORDAM, 1981).

Isto foi provavelmente devido à : (1) presença de agregados estáveis de protoplastos que não se separam sob a leve agitação a que o cultivo foi submetido; (2) aderência de protoplastos às paredes de vidro do frasco erlenmeyer e (3) presença de algum componente do meio que possa ter interferido ou alterado as leituras das densidades ópticas, como 6-BAP (6-benzil aminopurina), que tende a deslocar o pico de absorção luminosa para $\lambda=290 \mathrm{~nm}$.

\subsubsection{Medida do valor $W$}

O método mostrou-se preciso, rápido, de fácil execução e não-destrutivo; sendo, portanto, indicado para a avaliação de cultivos em suspensão de vários tipos. No entanto, também tem a desvantagem de não levar em consideração os protoplastos viáveis, mas o volume total presente na suspensão. 
Apesar disto o método ainda mostrou-se suficientemente sensível para refletir o estado físiológico do material, uma vez que foi possível a detecção do efeito do vírus e da substância viricida presente.

Os resultados obtidos por leituras de $\mathrm{W}$ foram eqüivalentes aos obtidos pela contagem direta de protoplastos ao microscópio óptico ( método direto). A equivalência é dada pelo valor de VCP, que pode ser transformado em número de protoplastos usando-se o valor médio do diâmetro de uma célula do mesófilo da espécie utilizada.

$O$ efeito da presença do VVCT detectado por este método foi maior no $\mathrm{x}_{\mathbf{0}}$ (inóculo inicial A) e menor na velocidade de crescimento (B), fazendo com que no início do cultivo a presença do vírus fosse mais prejudicial e reduzindo seu impacto com a passagem do tempo.

Os protoplastos em cultivo foram originários de folhas com infecção sistêmica uniforme, mas mesmo assim, supõe-se que nem todas as células protoplastizadas na suspensão possuíssem partículas de vírus no seu interior. Assim, as células sadias provavelmente multiplicam-se mais rápido originando novas células igualmente livres do vírus, fazendo com que, com o passar do tempo estas predominem no cultivo e atinjam a mesma velocidade de crescimento de um cultivo totalmente sadio.

O fato dos protoplastos estarem isolados uns dos outros, devido à ação do meio como uma barreira fisica, impede a transmissão direta de partículas virótica de uma célula à outra. (COUTTS, 1975; SANDER \& MERTES, 1984)

A ribavirina, ao contrário do que se poderia esperar, alterou significativamente o crescimento dos protoplastos em suspensão. Observou-se que a presença desta substância teve maior efeito sobre a velocidade de crescimento dos protoplastos e um efeito secundário sobre $0 \mathbf{x}_{\mathbf{0}}$. 0 material doente e tratado com ribavinina teve a menor velocidade de crescimento e foi o que atingiu menor produção final de biomassa, mas isto foi devido à presença do patógeno e à ação da própria ribavirina sobre os protoplastos.

Nos trabalhos iniciais com este produto observou-se a sua capacidade de inibir a biossintese de guanosina monofosfato (GMP), provocando uma diminuição no "pool" de guanina para a replicação do material genético do virus. Apesar desta reação estar presente tanto no vírus quanto no hospedeiro, observou-se uma seletividade para o material genético viral, que não foi satisfatoriamente explicada (STREETER et al., 1973; LERCH, 1977). No entanto, este mecanismo é aceito para células animais, sendo que para vegetais acredita-se que seja um passo metabólico anterior (GOSWAMI et al., 1979; DAWSON \& LOZOYA-SALDANA, 1984). 
Assim, uma vez que o modo de ação da ribavirina em células vegetais não é perfeitamente conhecido, este produto pode também ter tido alguma influência sobre o metabolismo dos protoplastos, quer seja na síntese de GMP, quer em algum processo anterior da replicação de seu RNA, sem que se observasse a ação seletiva sobre a replicação viral anteriormente mencionada.

Em condições de protoplastos, o nível de síntese de material genético viral é provavelmente menor do que num tecido ímtegro, devido ao meio de cultura não ser perfeito para sustentar o seu crescimento e a proliferação e devido aos estresses físicos e químicos aos quais a célula é submetida durante a protoplastização. Segundo SHEPARD (1977) estes são os motivos pelos quais a ribavirina não é eficiente para eliminação de vírus de protoplastos.

SIMPKINS et al. (1981) também observaram uma redução na velocidade de crescimento de material vegetal incubado com ribavirina, mas notaram a influência de outros fatores como : (1) concentração de ribavirina aplicada; (2) espécie de hospedeiro e (3) tipo de tecido infectado a receber tratamento.

O efeito da ribavirina na velocidade de crescimento dos protoplastos sugere que em cultivos mais longos a biomassa produzida dificilmente poderia atingir a do material não-tratado, enquanto que o material infectado com VVCT mas não tratado com o antiviral, tende a igualar-se ao sadio, como anteriormente observado (QUECINI et al., 1994).

\subsubsection{Método Direto}

O método direto foi o mais sensível quanto ao efeito da presença do VVCT (TSWV) e de ribavirina no cultivo, sendo que as equações de cinética de crescimento dos protoplastos foram reflexos fiéis das condiçōes físiológicas do cultivo. No entanto, não houve nenhum efeito que não fosse igualmente detectado pelo método indireto da leitura do valor $W$, como proposto inicialmente (GILISSEN et al., 1983) e previamente observado (QUECINI et al., 1994).

O padrão de crescimento dos protoplastos seguiu uma curva bacteriana, com "fase lag", "fase log" e "fase de desaceleração" bem definidas.

As alterações provocadas pela presença do VVCT e de ribavirina no padrão normal de crescimento de protoplastos em suspensão foram equivalentes às anteriormente discutidas para o método indireto de leitura do valor $\mathrm{W}$. 
5.2 Efeito da presença do VVCT e de Ribavirina sobre isoformas de peroxidase, shiquimato desidrogenase e amilase.

\subsubsection{Peroxidases}

Em ambas as hospedeiras sistêmicas do VVCT investigadas observou-se um aumento no número de isoformas desta enzima associado à presença do vírus, sendo que o mesmo já havia sido anteriormente relatado ( CLARE et al., 1966; COUTTS, 1978; WAGIH \& COUTTS, 1982a e 1982b; LUSSO, 1989; SHERIF et al., 1989).

Em petúnia, hospedeira com resposta hipersensível ao VVCT, observou-se um número de isoperoxidases maior do que o presente nas hospedeiras com resposta sistêmica, como previsto anteriormente (LOEBENSTEN, 1972; BELL, 19881; BOWLES, 1990), indicando que a hipersensibilidade está associada a um maior número de isoformas desta enzima. Todos os tratamentos envolvendo esta hospedeira, ou seja, sadio (S), doente (D) e doente tratado com ribavirina (R) mostraram o mesmo perfil eletroforético para peroxidases. Evidenciando que a hipersensibilidade apresenta-se associada a alterações bioquímicas como anteriormente constatado em outros trabalhos ( SEEVERS et al., 1971; BIRECKA et al., 1975; CZEK-KOSLOWSKA \& KRZYWANSKY, 1984; LAGRIMINI \& ROTHSTEIN, 1987; BRUCE \& WEST, 1989; REIMERS et al., 1992; MALOLEPSZA \& URBANEK, 1994).

0 tratamento quimioterápico com ribavirina não produziu efeito algum sobre as isoformas de peroxidase presentes nos três hospedeiros utilizados, um vez que o perfil destas isoenzimas foi idêntico ao doente para o material tratado com ribavirina. Considerando-se que a ribavirina atua sobre a replicação viral, mesmo que esta seja prejudicada ou reduzida pelo agente terapêutico, o perfil de isoperoxidases mantém-se distinto do material sadio, com a presença de isoformas induzidas inicialmente no processo de infecção.

No caso de infecções viróticas, é provável que a principal fimção das peroxidases seja : (1) oxidar compostos aromáticos produzidos pela via das hexoses monofosfato (HMP); (2) oxidar NADH e (3) eliminar o peróxido de hidrogênio, uma vez que a replicação das partículas de vírus no interior das células vegetais interferem com estes processos. A passagem do estado redutor de uma célula sadia normal para o oxidativo encontrado no caso da presença de agentes patogênicos, leva ao acúmulo e maior produção de enzimas oxidativas. 
As impressões das folhas em membranas de nitrocelulose constituíram-se em um método eficaz de detectar-se regiões de atividade alterada desta enzima no próprio mesófilio foliar. As soluções usadas na coloração dos géis foram igualmente eficientes para as membranas.

Através desta metodologia foi possível observar alta atividade de peroxidases ao redor das lesões necróticas nas folhas. $\mathbf{O}$ mesmo também ocorreu com lesões sistêmicas do vírus no tecido, mas de forma menos nítida e mais difusa por todo o mesófilo. 0 mesmo foi observado por COUTTS \& WAGIH (1982a) para o tecido vizinho às lesões necróticas, no entanto no presente trabalho não foi observado comportamento semelhante em tecidos mais distantes. É provável que isto seja devido ao papel das peroxidases na necrogênese, associadas à peroxidação de lipídeos e alterações na permeabilidade das membranas.

Muitos processo comuns associados às isoperoxidases ocorrem tanto para injúria mecânica e senescência quanto para o ataque por fitopatógenos, como por exemplo a biossíntese de lignina e etileno. Tomando assim, mais dificil a identificação precisa da causa que pode levar ao aumento nas isoformas de peroxidases em tecidos vegetais como constatado por SEEVERS et al. (1971), BIRECKA et al. (1975), CZEK-KOSLOWSKA \& KRZYWANSKY (1984), LAGRIMINI \& ROTHSTEIN (1987) e MALOLEPSZA \& URBANEK (1994).

Observou-se uma correlação negativa entre a presença de isoformas de peroxidase nas folhas e severidade do sintoma, sendo que o material hipersensivel apresentou mais isoformas da enzima e o material sistêmico, com sintomas que culminam com a morte da planta, apresentou menos isoperoxidases detectáveis.

O aumento no número de isoformas de peroxidase pode estar relacionado ao dano mecânico provocado no mesófilo pela inoculação do vírus, uma vez que a presença destas isoenzimas está associada aos processos de senescência ou dano mecânico ( SEEVERS et al., 1971; BIRECKA et al., 1975; WAGIH \& COUTTS, 1982a e b; CZEK-KOSLOWSKA \& KRZYWANSKY, 1984; LAGRIMINI \& ROTHSTEIN, 1987; BRUCE \& WEST, 1989; LUSSO, 1989; REIMERS et al., 1992; MALOLEPSZA \& URBANEK, 1994).

Com base nos resultados obtidos, reforça-se a associação de isoperoxidases aos processos patogênicos ou de dano mecânico, mas sem que se possa afirmar sua especificidade para algum deles, por não se saber a relação causa-efeito das peroxidases em materiais vegetais com resposta hipersensível ou exibindo sintomas sistêmicos na infecção viral. 


\subsubsection{Shiquimato desidrogenase}

Em plantas de tomate e de fumo, não se observou nenhuma atividade de shiquimato desidrogenase associada à presença do VVCT no material doente e tratado com ribavirina, confirmando observações anteriores (NADASKA \& ENDELSKI, 1991). Devido a importância da biossíntese dos aminoácidos aromáticos e do papel-chave da enzima nesta via, podemos sugerir que as alterações causadas pela presença de patógenos manifestam-se apenas em passos finais da mesma, envolvendo preferencialmente a PAL (fenilalanina-liase) (LAMB et al., 1989; BOWLES, 1990) ou na deidroshiquimato hidroliase ou shiquimato : NADP oxidorredutase (URITANI, 1971).

As plantas de petúnia sadia apresentaram uma isoforma da shiquimato desidrogenase. Esta isoshiquimato desidrogenase não foi observada para o material doente ou doente tratado com ribavirina, indicando que a presença do víns possa inibi-la, possivelmente pelo acúmulo de algum intermediário comum da via do ácido shiquímico que daria origem à escopoletina acumulada pelo tecido infectado com VVCT, como observado por BHASKARAN et al. (1974).

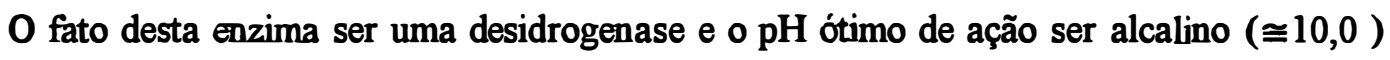
também são características que desfavorecem a sua participação direta na patogênese em que o estado celular geral é oxidativo (LOEBENSTEIN, 1972; BELL, 1981) e o pH, geralmente, ácido (BOWLES, 1990).

As impressões foliares em membranas de nitrocelulose não foram bem sucedidas para esta enzima, uma vez que a forte reação de fundo impediu uma detecção mais precisa de zonas com atividade alterada das isoshiquimato desidrogenases. No entanto, foi possível observar que existem diferenças de coloração na superficie do mesófilo impresso, sugerindo a presença de regiões com maior atividade desta enzima, embora a correlação com sítios lesionados não tenha sido nítida.

\subsubsection{Amilase}

Os padrões de isoamilases em fumo, tomate e petúnia obtidos não mostram efeito algum do VVCT nem da ação do agente quimioterápico utilizado, uma vez que tanto o material sadio quanto os outros tiveram o mesmo perfil eletroforético. 
Sugere-se, então, que a semelhança dos perfis obtidos tenha sido devida a : (1) pequena quantidade de amilase presente em mesófilos, (2) predominância das isoformas constitutivas e (3) alta especificidade das amilases associadas à patogenicidade (HEITZ et al., 1991) e não à falta de associação entre a presença de amilases e os processos patogênicos causados por vírus, uma vez que se tem relatado o acúmulo de amido (BELL, 1981) e aumento no consumo de carboidratos acumulados (URITANI, 1971), além de alterações na fotossíntese e respiração (DIENER, 1963) em tecidos vegetais doentes.

Os métodos de impressão de proteínas foliares em membranas de nitrocelulose não foram muito eficientes para a revelação da atividade de isoamilases, portanto não foram possíveis as conclusões relacionadas à atividade desta enzima e ao acúmulo/degradação de amido em tecidos vegetais atacados por vírus.

\subsection{Reutilização de enzimas líticas na obtenção de protoplastos}

0 reaproveitamento por duas vezes da solução de enzimas líticas na obtenção de protoplastos não teve efeito estatisticamente significativo sobre a cinética de crescimento dos mesmos em cultivo de suspensão. Portanto, podemos considerar nula a influência deste fator sobre os cultivos de protoplastos.

Observou-se que a "fase lag" ou de estabelecimento da cultura é um pouco mais lenta, sendo isto, provavelmente devido ao menor número de protoplastos viáveis produzidos pelas enzimas reutilizadas.

Segundo observações anteriores (FOWKE \& CONSTABEL, 1985) as soluções de enzimas líticas podem ser reaproveitadas até quatro vezes na obtenção de protoplastos, sem prejuízo algum ao crescimento e produção de biomassa da suspensão. No entanto, no presente trabalho, a partir da terceira reutilização da mesma solução de enzimas líticas observou-se uma acentuada redução no número de protoplastos obtidos, mesmo com uma compensação no tempo de incubação do material. Portanto, com uma redução no número de protoplastos o volume do cultivo teria que ser muito grande para que se alcançasse 0 valor de $\mathrm{x}_{0}$ (inóculo inicial) comparável ao obtido com enzimas usadas pela primeira vez. 
O aumento do tempo de incubação visando compensar a menor eficiência das enzimas líticas é limitado, uma vez que períodos muito longos (acima de 19 horas) implicam em alterações ambientais que podem influir no processo, uma vez que a temperatura e a iluminação afetam a hidrólise enzimática dos polímeros que compõem a parede celular vegetal. 


\section{CONCLUSÕES}

Os estudos realizados durante o presente trabalho permitiram chegar às seguintes conclusões :

1) A reutilização, por duas vezes, das enzimas líticas usadas para a obtenção de protoplastos do mesófilo foliar não apresenta nenhum prejuízo ao seu cultivo em suspensão, no que se refere à biomassa produzida e à velocidade de crescimento dos mesmos;

2) O método indireto de avaliação de crescimento proposto por GILISSEN et al. (1983) mostrou-se sensível o suficiente para detectar os efeitos testados de maneira equivalente ao método direto, além de ser rápido, de fácil utilização e não-destrutivo. Podendo, portanto, ser utilizado para cultivos de células e protoplastos em suspensão;

3) Houve correlação entre os estado fisiológico do cultivo e a sua cinética de crescimento, uma vez que os protoplastos infectados com VVCT (TSWV) tiveram menor produção de biomassa e menor velocidade de crescimento. $\mathbf{O}$ uso de uma substância viricida de amplo espectro de ação contra vírus de RNA e DNA - ribavirina - não foi eficaz para reverter esta situação no período de tempo avaliado, sendo que o efeito deste quimioterápico sobre a velocidade de crescimento do cultivo, observado na equação da cinética do material tratado, sugere que mesmo em cultivos mais extensos no tempo os valores de biomassa não possam se igualar ;

4) A impressão direta de tecidos ("tissue-blot") mostrou-se um método promissor para a detecção de alterações enzimáticas causadas por patógenos, uma vez que possibilitam uma avaliação in situ. No entanto, ainda são necessários novos testes para aprimorar a metodologia para alguns tipos de enzima; 
5) As isoperoxidases estão associadas ao desenvolvimento do processo patogênico provocado pela presença do VVCT ou às injúrias mecânicas causadas nos mesófilos foliares, uma vez que suas isoformas foram induzidas com a inoculação deste vírus em hospedeiros com resposta sistêmica, tomate (Lycopersicon esculentum Mill.) e fumo (Nicotiana tabacum L.). No entanto, não se pode sugerir a existência de espocificidade com base nos estudos realizados. Estas isoenzimas mostraram-se correlacionadas à hipersensibilidade ao vírus em petúnia (Petunia hybrida Vilm.);

6) Não observou-se correlações consistentes entre a presença de isoformas de shiquimato desidrogenase presente no tecido e infecção com VVCT;

7) Não se obteve relações entre o perfil eletroforético de isoamilases e a presença do VVCT no organismo do hospedeiro. 


\section{REFERÊNCIAS BIBLIOGRÁFICAS}

AGRAWAL, H.O. Plant virus replication. Indian Phytopathology, New Delhi, 42(3) : 369-387, 1989.

ALFENAS, A.C.; BRUNE,W.; BROMMOSCHENCKEL,S.H. Manual de eletroforese de proteínas $\mathrm{e}$ isoenzimas em géis de amido e poliacrilamida. Viçosa, Universidade Federal de Viçosa (UFV), 1987. 74p.

ALTHAUS, I.W.; CHOU, J.J.; GONZALES, A.J.; LeMAY, R.J.; DEIBEL, M.R.; CHOU, K.C.; KESDY, F.J.; ROMERO, D.L.; THOMAS, R.C.; ARISTOFF, P.A.; TARPLEY, W.G.; REUSSER,F. Steady-state kinetic studies with polysulfonate U-9843, an HIV reverse transcriptase inbibitor. Experientia, Basel, 50 (1) : 23-28, 1994.

AMINUDDIN \& SINGH,B.P. Petunia hybrida Hort. explant culture effect of virazole and certain dyestuff on Petunia MosaicVirus elimination. Indian Phytopathology, New Delhi, 38 (4) :692-694, 1985.

AMOROS, M.; SAUVAGER, F.; GIRRE, L.; CORMIER, M. In vitro antiviral activity of propolis. Apidologie, Paris, 23 (3) : 231-240, 1992.

ANDRAE, W.A. Effect of scopoletin on indolacetic acid metabolism. Nature, London, 170 (1) : 83-84, 1952.

ATABEKOV, J.G. \& MOROZOV, S.Y.U. Tranlation of plant virus messenger RNAs. Advances in Virus Research, San Diego, 25 :1-91, 1979. 
ÁVILA, A.C de Diversity of Tospovinus. Wageningen, 1992. 136p. (Doutorado Landbouwrniversiteit te Wageningen).

BALD, J.G. Cytological evidence for the production of plant virus ribonucleic acid in the nucleus. Virology, New York, 22 (2) : 377-387, 1964.

BALD, J.G. Citology of plant virus infections - tomato spotted wilt virus. Advances in Virus Research, San Diego, 12 : 103-122, 1966.

BALINSKY, D. \& DAVIES, D.D. Aromatic biosynthesis in higher plants. 1. Preparation and properties of dehydroshikimic reductase. Biochemistry Journal, Tokyo, 80 (2) : 292-296, 1961 a.

BALINSKY, D. \& DAVIES, D.D. Aromatic biosymthesis in higher plants. 2. Mode of attachment of shikimic acid and dehydroshikimic acid to dehydroshikinic reductase. Biochemistry Journal, Tokyo, 80 (2) : 296-300, 1961 b.

BALINSKY, D. \& DAVIES, D.D. Aromatic biosynthesis in higher plants. 3.

Preparation and properties of dehydroquinase. Biochemistry Journal, Tokyo, 80 (2) : 300-304, 1961c.

BALLS, A.K.; WALDEN, M.K.; THOMPSON, R.R. A crystallime $\beta$-amilase from sweet potatoes. Journal of Biological Chemistry, Baltimore, 173 (1) : 9-19, 1948.

BARACHO, I.R. Bases for the living process theory. Ciência e Cultura, Campinas, 37 (1) : 25-30, 1983.

BARRADAS, M.M.; ALEXANDRE, M.A.V.; VICENTE, M. Solanáceas silvestres como hospedeiros expenimentais de víns. IV Solanum fastigiatum Wield., $S$. grandiflorum R., S. sisymbrifolium Lam.. Arquivos do Instituto Biológico, São Paulo, 49 (114) : 43-49,1982. 
BARRADAS, M.M. \& FERRARI, J.T. Petunia integrifolia var. integrifolia, hospedeira experimental de virus. Arquivos do Instituto Biológico, São Paulo, $95(1 / 2)$ : 43-48, 1992.

BATES, G.W.; GAYNOR, J.J.; SHEKHAWAT, N.S. Fusion of plant protoplasts in electric fields. Plant Physiology, Rockville,72 (4) : 1110-1113, 1983.

BAUER, U.; KLUGE, S.; NUHM, P.; STENGER, P.; LETTAU, H. Enantioselective antiphytoviral activity of 1-(alphacarboxyalkil)-4,5-dimethyl 1 imidazol-3 oxides in sistematically infected host plants. Joumal of Phytopathology, Berlin, 137 (4) : 309-316, 1993.

BELDING, M.E. \& KLEBANOFF, S.J. Peroxidase-mediated virucidal systems. Science, New York, 167 (3915) : 195-196, 1970.

BELL, A.A. Biochemical mechanisms of disease resistance. Annual Review of Plant Physiology, Palo Alto, 32 : 21-81, 1981.

BEST, R.J. Tomato Spotted Wilt Virus. Advances in Virus Research, San Diego, 13 : 65-146, 1968.

BHASKARAN, R.; PURSHOTAMAN, D.; RANGANATHAN, K. Physiological changes in rose leaves infected by Diplocarpon rosae. Phytopathologische Zeitschrift, Berlin, 79 (3) : 231-236, 1974.

BIRECKA, H.; CATALFAMA, J.L.; GARRAWAY, M.O. Cell wall and protoplast isoperoxidases of com leaves in relation to cut injury and infection with Helminthosporium maydis. Plant Physiology, Rockville, 55 (4) : 607-610, 1975.

BLACK, L.M.; BRAKKE, M.K. VATTER, A.E. Purification and electron microscopy of Tomato Spotted Wilt Virus. Virology, New York, 20 (2) : 120-130, 1963.

BOITEUX, L.S.; CUPERTINO, F.P.; REIFSCHNEIDER, F.J.B. Capsicum chinense PI 159236 : a source of resistance to Phytophthora capsici and tomato 
spotted wilt virus (TSWV). Capsicum and Eggplant Newsletter, Lexingtom, 12 : 76, 1993.

BOITEUX, L.S.; NAGATA, T.; DUSI, A.N.; ÁVILA, A.C.de Natural occurence of two tospovirus species infecting Capsicum spp. in Brazil. Capsicum and Eggplant Newsletter, Lexington, 12 : 75,1993.

BOL, J.F.; RHEE, M.D. van de; BREDERODE, F.T.; LINTHORST, HJ.M. Expression of PR protein genes in response to virus infections and other stress conditions. In : FRITIG, B. \& LEGRAND, M. eds. Mechanisms of plant defense responses. Dordrecht, Kluwer Academic Publishers, 1993. 268-275p.

BOS, L. Introduction to Plant Virology. $2^{\text {a }}$ ed. London, Longman Group Limited. 1983. 160p.

BOWLES, D.J. Defense-related proteins in higher plants. Annual Review of Biochemistry, Palo Alto, 59 : 873-907, 1990.

BRADFORD, M.M. A rapid and sensitive method for the quantification of microgram quantities of protein utilizing the principle of protein-dye binding. Analytical Biochemistry, New York, 72 (4) : 248- 254, 1976.

BRAR, D.S.; RAMBOLD, S.; CONSTABEL, F.; GAMBORG, O.L. Isolation, fusion and culture of sorghum and corn protoplasts. Zeitschrift fur Pflanzenphysiologie, Berlin, 96 (2) : 269-275, 1980.

BROADBENT, A.B.; ALLEN, W.R.; FOOTIT,R.G. The association of Frankliniella occidentalis (Pergande) (Thysanoptera : Thripidae) with greenhouse crops and the tomato spotted wilt virus in Oitario. Canadian Entomologist, Ottawa, 119 (5) : 501-503, 1987.

BRUCE, R.J. \& WEST, C.A. Elicitation of lignin biosynthesis and isoperoxidase activity by pectic fragments in supension cultures of castor bean. Plant Physiology, Rockville, 91 (3) : 889-897, 1989. 
BYHAN, O.; KLUGE, S.; PUSTOWOIT, B.; PUSTOWOIT, W.; SCHUSTER,G. Effect of 1- $\beta$-D-ribofuranosyl-1,2,4-triazole-3-carboxamide (virazole) on synthesis and concentration of tobacco mosaic vinus RNA, host RNA and host proteins. Biochemie und Physiologie der Pflanzen, Jena, 173 (5) : 521-535, 1978.

CHEN, H.R.; HOSOKAWA, D.; WATANABE, M. Resistance to tobacco mosaic virus in tobacco cultivar Ambalema : multiplication of the virus in leaf tissues and mesophyll protoplasts. Annals of Phytopatological Society of Japan, Tokyo, 56 (1) : 5662, 1990.

CHO, J.J.; MAU, R.F.L.; HAMASAKI, R.T.; GONSALVES, D. Detection of tomato spotted wilt virus by enzyme-linked immunosorbent assay. Phytopathology, Lancaster, 78 (10) : 1348-1352, 1988.

CLARE, B.; WEBER, D.J.; STAHMANN, M.A. Peroxidase and resistance to Ceratocystis in sweet potato increased by volatile materials. Science, New York, 153 (3731) : 62-63, 1966.

COCKING, E.C. A method for the isolation of plant protoplasts and vacuoles. Nature, London, 187 (5) : 927-929, 1960.

COCKING, E.C. Plant cell protoplasts - isolation and development. Annual Review of Plant Physiology, San Diego, 23 : 29-50, 1972.

CORNUET, P. Éléments de Virologie Vegetale. Paris, INRA - Institut National de la Recherche Agronomique. 1987. 206p.

COSTA, A.S. \& SILVA, D.M. Origem do fumo TNN, planta-teste padrão na Seção de Virologia do Instituto Agronômico de Campinas. In : CONGRESSO PAULISTA DE FITOPATOLOGIA, 12., Araras, 1989. Resumo dos Trabalhos. Summa Phytopathologica, Jaguariúna, 15 (1) : 41, jan./mar., 1989. 
COUTTS, R.H.A. Suppression of virus-induced local lesions in plasmolysed leaf tissue. Plant Science Letters, Amsterdam, 12 (1) : 77-85, 1975

COUTTS, R.H.A. Alterations in the solubel protein pattems of tobacco and cowpea leaves following inoculation with tobbaco necrosis virus. Plant Science Letters, Amsterdam, 12 (2) : 189-197, 1978.

COUTTS, R.H.A. \& WAGIH, E.E. Alterations in RNA and protein metabolism in uninoculated half- leaves of cowpea adjacent to tobacco necrosis virus infected halves. Plant Science Letters, Amsterdam, 21 (1) : 51-59, 1981.

COUTTS, R.H.A. \& WAGIH, E.E. Induced resistance to viral infection and soluble protein alterations in cucumber and cowpea plants. Phytopathologische Zeitschrift, Berlin, 107 (1) : 57-69, 1983.

CULBREATH, A.K.; TODD, J.W. DEMSKI, J.W.; CHAMBERLIN, J.R. Disease progress of spotted wilt in peanut cultivars Flonmner and South Rumner. Phytopathology, Lancaster, 82 (7) : 766-771, 1992.

CUTT, J.R; \& KLESSIG, D.F. Pathogeneis-related proteins. In : BOLLER, T. \& MENS, F. eds. Genes involved in plant defense. Vienna, Springer-Verlag Publishers, 1992. 209-253p.

CZEK-KOZLOWSKA, M. \& KRZYWANSKI, Z. Phenolic compounds and the polyphenoloxidase and peroxidase activity in callus tissue culture pathogen combination of red raspberry and Didymella applanta (Niersl.) Sacc..

Phytopatolosgische Zeitschrift, Berlin, 109 (2) : 176-182, 1984.

DARGAN, D.J.; GALT, C.B.; SUBAK-SHARP, J.H.; The effect of cicloxolone sodium on the replication of vesicular stomatitis virus in B5C-1 cells. Journal of General Virology, London, 73(2) : 397-406, 1992 a. 
DARGAN, D.J.; GALT, C.B.; SUBAK-SHARP, J.H.; The effect of cicloxolone sodium on the replication in cultured cells of Adenovirus type 5, Reovinus type 3, Poliovirus type 1, two Bumyavirus and Semliki Forest virus. Journal of General Virology, London, 73 (2) : 407-411, $1992 \mathrm{~b}$.

DAVIES, J.W. Molecular Plant Virology. vol II (replication and gene expression). Boca Raton, CRC Press, 1985, 493p.

DAWSON, W.O. \& LOZOYA-SALDANA, H. Examination of the mode of action of ribavirm agaisnt tobbaco mosaic virus. Intervirology, Basel, 22 (1) : 77-84, 1984.

DIENER, T.O. Physiology of virus-infected plants. Annual Review of Phytopathology, Palo Alto, 1 : 197-218, 1963.

DIXON, R.A. Isolation and maintenance of callus and cell suspensions cultures. In : DIXON, R.A. ed. Plant cell culture : a practical approach. $2^{a}$ ed. Oxford, IRL Press, 1987, cap.1 p.1-20. (Practical Approach Series)

DMITRIEVA, N.N.; VINNIKOVA, N.V.; ERNAKOV, I.P.; MATVEEVA, N.P. Early response of chromatin to auxin in tobacco protoplasts. Soviet Plant Physiology, Moscow, 35 (5/1) : 673-680, 1988.

DUMAS, B.; JAECK, E.; SLINTZI, A.; RAUSTER, J.; KAUFFMANN, S.; GEOFFROY,P.; KOPP, M.; LEGRAND, M.; FRITIG, B. Plant genes involved in resistance to virus. In : PLANT MOLECULAR BIOLOGY 2., Elmau, 1990. Procedings. Elmau, NATO Advanced Study Institure, 1990. v.212. (NATO ASI Series)

ENYEDI, A.J.; YALPANI, N.; SILVERMAN, P.; RASKIN, I. Signal molecules in systemic plant resistance to pathogens and pests. Cell, Cambridge, 70 (5) : 879-886, 1992. 
ERIKSSON, B.; HELGSTRAND, E.; JOHANNSON, N.G.; LARSSON, A.; MISIORNY, A.; $\quad$ NOREN, J.O.; PHILIPSON, L.; STENBERG, K.; STENING, G.; STRIDIH, S.; OBERG, B. Inhibition of influenza ribonucleic polymerase. Antimicrobial Agents and Chemotherapy, Detroit, 11 (6) : 946-951, 1977.

ERIKSSON, T.R Protoplasts isolation and culture. In : FOWKE,L.C \& CONSTABEL, F. eds. Plant Protoplasts. Boca Raton, CRC Press, 1985. capl. p.1-19.

EVERAERT, L.; VRIJSEN, R.; BOEYÉ, A. Eclipse products of poliovinus after coldsynchronized infection of HeLa cells. Virology, New York, 171 (1) : 76-82, 1989.

FARMER, E.E. \& RYAN, C.A. Octadecanoid precursors of jasmonic acid activate the synthesis of wound-inducible proteinase inhibitors. The Plant Cell, Baltimore, 4 (2) : 129-134, 1992.

FÁZIO, G. de; CANER, J.; VICENTE, M. Inhibitory effect of virazole (ribavirin) on the replication of tomato white necrosis virus (VNBT). Archives of Virology, New York, 58 (2) : 153-156, 1978.

FÁZIO, G. de; CANER, J.; VICENTE, M. Effect of virazole (ribavirin) on tomato spotted wilt vinus in two systemic hosts, tomato and tobacco. Archives of Virology, New York, 63 (5) : 305-309, 1980a.

FÁZIO, G. de; KUDAMATSU, M.; VICENTE, M. Virazole pretreatments for the prevention of tomato spotted wilt vinus (TSWV) systemic infection in tobacco plants, Nicotiana tabacum L. White Burley. Fitopatologia Brasileira, Brasilia, 5 (3) : 343-349, $1980 \mathrm{~b}$.

FÁZIO, G. de; KUDAMATSU, M.; VICENTE, M. Efeito antiviral do ácido acetil-salicílico e do ácidoacrílico sobre o víns do vira-cabeça do tomateiro (Br. TSWV) em plantas de fumo. Fitopatologia Brasileira, São Paulo, 12 (1) : 53-57, 1987. 
FERRARI, T.E.; PALMER, J.E.; WIDHOLM, J. Monitoring protoplast production from plant cells. Plant Science Letters, Amsterdam, 4 (2) : 145-149, 1975.

FLEET, D.S. van Histochemistry and function of the endodermis. Botanical Reviews, New York, 27 (2) : 165-214, 1961.

FRANCKI, R.I.B. \& GRIVELL, C.J. An electron microscope study of the distribution of tomato spotted wilt virus in systemically infected Datura stramonium leaves. Virology, New York, 42 (4) : 969-978, 1970.

FRANCKI, R.I.B.; HATTA, T. Tomato spotted wilt virus. In : KURSTAK,E.(ed) Handbook of plant virus infections and comparative diagnosis. Amsterdam : Elsevier/North Holland Biomedical Press. 1987. cap.17, p.492511.

FOWKE, L.C. \& CONSTABEL, F.eds Plant Protoplasts. Boca Raton, CRC Press, 1985. 245p

GERA, A.; LOEBENSTEIN, G.; SALOMON, R.; FRANCK, A. Inhibitor of virus replication from protoplasts of a hypersensitive tobacco cultivar infected with tobacco mosaic virus in association with a $23 \mathrm{~K}$ protein species. Phytopatology, Lancaster, 80 (1) : 78-81, 1990.

GIELEN, J.J.L.; HAAN,P.de; KOOL, A.J.; PETERS, D.; GRINSVEN, M.Q.J.M.van; GOLDBACH, R.W. Engineered resistance to tomato spotted wilt virus, a negative strand RNA virus. Bio/Technology, Amsterdam, 9 (12) : 1363-1367, 1991.

GILISSEN, L.J.W.; HÄNISCH-TEN-CATE, C.H.; KEEN, B. A rapid method of determining growth characteristics of plant cell populations in batch suspensions. Plant Cell Reports, New York, 2 (3) : 232-235, 1983. 
GLIMELIUS, K.; WALLIN, A.; ERICKSSON, T.C. Agglutination effects of concavalin A on isolated protoplasts of Daucus carota. Physiologia Plantarum, Copenhagen, 31 (2) 225-231, 1974.

GLUND, K.; ABEL, S. Structural dynamics of the vacuolar system in cultured tomato cells : a direct isolation study. Journal of Plant Physiology, Washington, 135 (2) : 242- 244, 1989.

GOFFLOT, A. \& VERHOYEN, M. Speecty development of tomato spotted wilt virus infection transmitted by Frankliniella occidentalis in omamental greenhouse cultivars in Belgium. Parasitica, Bruxelles,46 (2-3) : 85-88, 1990.

GONZALES, J.P.; CORNET, J.P.; WILSON, M.L.; CAMICAS, J.L. Crimean-Congo haemorragic fever virus replication in adult Hyalomma truncatum and Amblyomma variegatum ticks. Research in Virology, Paris, 142 (0) : 483-488, 1991.

GOSWAMI, B.B.; BOREK, E.; SHARMA, O.K. The broad spectum antiviral agent ribavirin inhibits capping of mRNA. Biochemical and Biophysical Research Communications, New York, 89 (7) : 830-836, 1979.

GREEN, J.L.; ALLEN, T.C.; FISHER, S. Tomato spotted wilt virus in stephanotis in an Oregon greenhouse. Plant Disease, Saint Paul, 73 (10) : 92, 1988.

GRENECHE, M.; LALLEMAND, J.; MICHAUD,0. Comparation of different enzyme loci as a means of distinguishing ryegrass varieties by electrophoresis. Seed Science and Technology, Zurich, 19 (1) : 147-158, 1991.

GROSSET, J.; MEYER, Y.; CHARTIER, Y.; KAUFFMANN, S.; LEGRAND,M.; FRITIG, B. Tobacco mesophyll protoplasts synthetize 1,3- $\beta$-glucanase, chitinases and "osmotins" during in vitro culture. Plant Physiology, Rockville, 92 (2) : 520-527, 1990. 
HALL, R.D.; ROWENDAL, G.J.A.; KRENS, F.A. Asymetric somatic cell hybridization in plants. Molecular and General Genetics, London, 234 (3) :234-306, 315-324, 1992.

HALLIWELL, R.S. \& JOHNSON, J. Virus diseases of spinach in Texas winter gardens. Lexington, Texas Agriculture Experimental Station,. 1988. 4p.

HAMMERSCHMIDT, R.; NUCKLES, E.M.; KÚC, J. Association of enhanced peroxidase activity with induced systemic resistance of cucumber to Colletothricum lagenarium. Physiology of Plant Pathology, London, 20 (1) : 73$82,1982$.

HAAN, P. de; ÁVILA, A.C. de; KORMELINK, R.; WESTERBROEK, A.; GIELEN, J.J.L.; PETERS, D.; GOLDBACH, R. The nucleotide sequence of the SRNA of Impatiens necrotic spot virus, a novel tospovinus. FEBS Letters, Cambridge, 306 (1) : 27-32, 1992.

HAAN, P.de ; KORMELINK, R.; RESENDE, R.de O.; van POELWUK, F.; PETERS, D.; GOLDBACH, R. Tomato spotted wilt vinus LRNA encodes a putative RNA polymerase. Journal of General Virology, London, 72 (9) : 2207-2216, 1991.

HAAN, P. de; WAGEMAKER, L.; PETERS, D.; GOLDBACH, R. The S RNA segment of tomato spotted wilt virus has an ambisense character. Journal of General Virology, London, 71 (8) : 1001-1007, 1990.

HARMSEN, T.; VEENENDAAL, D.van; KRAAUEVELD, C.A. Inhibition of Semliki Forest vinus multiplication in L-cells by combination of imterferon and ribavirin as measured by plaque titration and direct enzyme immunoassay. Zentralblatt für Bakteriologie, Amsterdam, 280 (3) : 386-391, 1994.

HASHEMI, A.; ESTILAI, A.; EHDAIE,B. Inheritance of aconitase, shikimate dehydrogenase and phosphoghucose isomerase in guayole. Journal of the American Society of Horticultural Science, Geneva, 116 (4) : 737-739, 1991. 
HAUSBECK, M.K.; WELLIVER, R.A.; DERR, M.A.; GILDOW, F.E Tomato spotted wilt vinus survey among greenhouse ornamentals in Pennsylvania. Plant Disease, Saint Paul, 76 (8): 795-800, 1992.

HEITZ, T.; GEOFFROY, P.; FRITIG, B.; LEGRAND, M. Two apoplastic $\alpha$-amilases induced in tobbaco by virus infection. Plant Physiology, Rockville, $97(2)$ : 651-656, 1991.

HOKAMA, K.; TOKAHASHI, I. Yield loss of cucumber infected with tomato spotted wilt vinus. Procedings of the Association of Plant Protection of Kyushu, Kyushu, 33 : 39-41, 1987.

HORIBE, I.Y. Perfis eletroforéticos de proteínas e ácidos nucleicos totais de extratos de : Lycopersicon esculentum Mill., Lycopersicon pimpinellifolium Mill., Lycopersicon peruvianum Mill. infectados com o vírus "vira-cabeça" do tomateiro. Piracicaba, 1990. 147p. (Mestrado-Escola Superior de Agricultura "Luiz de Queiroz" / USP).

HU, J.S.; WANG, M.; FERREIRA, S.; OGATA, D. Tomato spotted wilt virus on Oncidium orchids in Hawaii. Plant Disease, Saint Paul, 76 (4): 426, 1992.

HURK, J.van den ; TAS, P.W.L.; PETERS, D. The ribonucleic acid of tomato spotted wilt virus. Journal of General Virology, London, 36 (1) : 81-91, 1977.

HUSSAIN, Z. \& MUHAMMAD, K. Effect of virazole on the replication of Newcastle disease virus in embryonated eggs. Pakistan Veterinary Journal, Tanbojām, 7 (3) : 92-94, 1987

HSU, H.T. \& LAWSON, R.H. Direct tissue blotting for detection of tomato spotted wilt virus in Impatiens. Plant Disease, Saint Paul, 75 (3) : 292-295, 1991.

IE, T.S. Electron microscopy of develomental stages of tomato spotted wilt virus in plant cells. Virology, New York, 43 (2) : 468-479, 1971. 
IE, T.S. A sap-transmissible, defective form of tomato spotted wilt virus. Journal of General Virology, London, 59 (2) : 387-391, 1982.

INBAR, J. \& CHET, I. Evidence that chitinase produced by Aeromonas caviae is involved in the biological control of soil-bome pathogens by this bacterium. Soil Biology and Biochemistry, Oxford, 23 (10) : 973-978, 1991.

ISHIKAWA,M.; MESHI,T.; OHNO,T.; OKADA,Y. Specific cessation of minusstrand RNA accumulation at an early stage of tobacco mosaic virus infection. Journal of Virology, Washington, 65 (2) : 861-868, 1991.

IWAKI, M.; HONDA,Y.; HANADA, K.; TACHIHARO, H.; YONAHA, T.; HOKAMA, K.; YOKOYAMA, T. Silver mottle disease of watermelon caused by tomato spotted wilt virus. Plant Disease, Saint Paul, 68 (11) : 1006-1008, 1984.

JAYASENA, K.W.; REDDY, D.V.R; RAJAPAKSE, R.HS. First report of tomato spotted wilt virus infecting peanut in Sri Lanka. Plant Disease, Saint Paul, 72 (10) : 912, 1988.

JUNG, J.L.; BOUZAUBAA, S.; GILMER, D.; HALME, G. Visualization of transgene expression at the single protoplast level. Plant Cell Reports, New York, 11 (7) : 346-350, 1992.

KAMMEN, A. van ; HENSTRA, S.; IE, T.S. Morphology of tomato spotted wilt virus. Virology, New York, 30 (2) : 574-577, 1966.

KANAI, R. \& EDWARDS, G.E. Purification of enzymatically isolated mesophyll protoplasts from $\mathrm{C} 3, \mathrm{C} 4$ and crassulaceam acid metabolism plants using an aqueous dextran polyethylene glycol two-phase system. Plant Physiology, Rockvile, 52 (2) : 484-490, 1973. 
KIM, J.W.; GERMAN, T.L.; SUN, S.S.M. Viral protection in transgenic tobbaco plants expressing theTSW virus N-gene-transgenic plant construction with virus disease resistance. Hortscience, Saint Joseph, 27 (๑) : 621, 1992.

KINO-OKA, M.; TAYA, M.; TONE, S. Evaluation of mhibitory effect of ammonium ion on cultures of plant hairy roots -Rubia tinctorum, bectroot and carrot hairy root. Culture medium optimization and kinetic model. Journal of Chemical Engeneering of Japan, Tokyo, 26 (5) : 578-580, 1993.

KITAJMA, E.W. Electron microscopy of vira-cabeça vinus (Brazilian Tomato Spotted Wilt Virus) within the host cell. Virology, New York, 26 (1) : 89-99, 1965.

KITAIMA, E.W.; RESENDE,R.de O.; ÁVILA, A.C.de; GOLDBACH, R.W.; PETERS, D. Immuno-lectron microscopical detection of tomato spotted wilt virus and its nulceocapsids in crude plant extracts. Journal of Virological Methods, Amsterdam, 38(3): 313-322, 1992a.

KITAJIMA, E.W.; RESENDE, R.de O.; ÁVILA, A.C.de; GOLDBACH, R.H.; PETERS, D. Comparative cytological and immunogold labelling studies on different isolates of tomato spotted wilt virus. Journal of Submicroscopical Cytology and Pathology, Zurich, 4 (1) : 1-14, 1992 b.

KOBATAKE, H.; OSAKI, T.; INOYE, T. The vector and reservoirs of tomato spotted wilt virus in Nora Perfecture. Annals of the Phytopathological Society of Japan, Tokyo, 50 (4) : 541-544, 1984.

KORMELINK, R.; HAAN, P de ; MEURS, C.; PETERS, D.; GOLDBACH, R. The nucleotide sequence of the M RNA segment of tomato spotted wilt virus : a plantinfecting bunyavirus with two ambisense RNA segments. Journal of General Virology, London, 73 (11) : 2795-2804, 1992c. 
KORMELINK, R; HAAN, P. de ; PETERS, D.; GOLDBACH, R Viral synthesis in tomato spotted wilt virus-infected Nicotiana rustica plants. Journal of General Virology, Londan, 73 (3) : 687-693, 1992a.

KORMELINK, R; POELWIJK, F. van ; PETERS, D.; GOLDBACH, R Non-viral heterogenous sequences at the 5' ends of tomato spotted wilt virus (TSWV) mRNAs. Journal of General Virology, London, 73 (8) : 2125-2128, $1992 \mathrm{~b}$.

KORMELINK, R; STORMS, M.; LENT, J. van ; PETERS, D.; GOLDBACH, R Expression and subcellular location of the NSm protein of tomato spotted wilt virus (TSWV) a putative viral moviment protein. Virology, New York, 200 (1) : 56-65, 1994.

LAEMMLI, U.K. Cleavage of structural proteins during the assembly of the head of Bacteriophage T4. Nature, London, 227 (5) : 680-685, 1970.

LAGRIMINL, L.M. \& ROTHSTEIN, S. Tissue specificity of tobacco peroxidase isozymes and their induction by wounding and tobacco mosaic virus infection. Plant Physiology, Rockville, 84 (2) : 438-442, 1987.

LAMB, G.J.; LAWTON, M.A.; DRON, M.; DIXON, RA. Signals and transtuction mechanisms for activation of plant defenses against microbial attack. Cell, Cambridge, 56 (1): 215-244, 1988.

LARKIN, P.J.; YOUNG, M.J.; GERLACH, W.L.; WATERHOUSE, P.M. The Yd2 resistance gene to barley yellow dwarf virus is effective in barley plants bu not in their leaf protoplasts. Annals of Applied Biology, New York, 118 (1) : 115-125, 1991.

LEAL, D.P.; ISLA, M.I.; VATTUONE, M.A.; SAMPIETRO, A.R Production of plant protoplasts by enzymes from selected wood-destroying fungi. Applied Microbiology and Biotechnology, Vienna, 41 (1) : 58-61, 1994. 
LENT, J.van; STORMS, M.; MEER, F.van der; WELLINK, J.; GOLDBACH, R.W. Tubular sturctures involved in movement of cowpea mosaic virus are also formed in infected cowpea protoplasts. Journal of General Virology, London, 72 (11) : 2615-2653, 1991.

LERCH,B. Inhibition of the bisynthesis of potato vinus $\mathrm{X}$ by ribavirin.

Phytopathologische Zeitschrift, Berlin, 89 (1) : 44 49, 1977.

LIMA, M.L.R.Z. da C. \& SOUZA, V.B.V.de Ocorrência do vírus do vira-cabeça do tomateiro em culturas de abobrinha no município de Colombo-PR.. Revista do Setor de Ciências Agrárias, Curitiba,10 (1-2) : 171-173, 1988.

LINDGRUN, P.B.; JAKOBEK, J.L.; SMITH, J.A. Molecular analysis of plant defense responses to plant pathogens. Journal of Nematology, Riverside, 24 (3) : 330-33, 992.

LOEBENSTEIN, G. Localization and induced resistance in vinus infected plants. Annual Review of Plant Pathology, Kew, 10 : 177-206, 1972.

LOEBENSTEIN, G.; GERA, A.; BARNETT, A.; SHABATI, S.; COHEN, J. effect of 2,4dichlorophenoxyacetic acid on multiplication of tobacco nosaic virus in protoplasts from local-lesion and systemic-responding tobaccos. Virology, New York, 100 (1) : 110-115, 1980.

LOI, J.S.; LEE, S.M.; LAM-CHAN, I.T.; FAN, S.; YIANG, W.H. Eradication of orchid viruses in Dendrobium sonia using virazole. Singapore Journal of Primary Industries, Singapore, 19 (1) : 16-22, 1991.

LOTAN, T. \& FLUHR, R. Xylanase, a novel elicitor of pathogenesis-related proteins in tobacco, uses a non-thylene pathway for induction. Plant Physiology, Rockville, 93 (2) : 811-817, 1990. 
LU, W.; MANOLIKAKIS, G.; ANDRIEU, J.M. Relationship between frequency of infectious human immunodefiency virus typel harbouring cells and kinetics of viral replication : a simple procedure for quantification of infectious viruscarrying cells in blood samples. Journal of Clinical Microbiology, London, 30 (10) : 2535-2538, 1992.

LUCY, J.A. Do hydrophobic sequences cleaved from cellular polypeptides induce membrane fusion reactions in vivo ? FEBBS Letters, Cambridge, 166 (2) : 223-231, 1984.

LUSSO, M.F. de G. Alterações na atividade e no perfil eletroforético da enzima peroxidase em mesocótilos e folhas de milho (Zea mays $\mathrm{L}$.) em resposta à inoculação com Helminthosporium mayydis Nisik. \& Miy., raça 0, Helminthosporium carbonum Ullstrup, raça 1 e à injúria mecânica. Piracicaba, 1989. 109p. (Mestrado - Escola Superior de Agricultura "Luiz de Queiroz" / USP).

MAISS, E.; IVANOVA, L.; BEYEL, E.; ADAM, G. Cloning and sequencing of the S RNA from a Bulgarian isolate of tomato spotted wilt virus. Journal of General Virology, London, 72 (2) : 461-464, 1991.

MALOLEPSZA, U. \& URBANEK, H. Changes in peroxidase activity in bean suspension cultures after B.cinerea and elicitor treatment. Journal of Phytopathology, Berlin, 141 (3) : 314-322, 1994.

MANDELSTAM, J.; McQUILLEN, K; DAWES, I. eds. Biochemistry of bacterial growth. $3^{a}$ ed. Oxford, Blackwell Scientific Publications, 1982. 449p.

MAOKA,T. \& USUGI, T. Epidemiology of tomato spotted wilt virus of cucumber in vinyl house culture in Ishigaki Island. Proceedings of the Association of Plant Protection of Kyushu, Kyushu, 37 : 42-46, 1991. 
MARCHOUX, G. Interactions entre virus ou entre virus et leurs satellites chez un hôte commun. II. Interférences positives : synergie, complementation et assistance. Agronomie, Paris, 8 (๑) : 471-490, 1988.

MARIS, P. Étude de l'activité virucide in vitro des desinfectant au moyen de deux méthodes. Annales des Recherches Veterinaires, Paris, 17 (2) : 115-122, 1986.

MATTIONI, J.A.; ALLEN, W.R.; BROADBENT, A.B. Tomato spotted wilt virus in greenhouse crops in Ontario. Plant Disease, Saint Paul, 72 (9) : 801, 1988.

METRAUX, J.P.; GOY, P.A.; STAUB, T. SPEICH, J.; STEINEMANN,A.; RYALS, J.; WARD, E.Induced systemic resistance in cucumber in response to 2,6-dichloro-isonicotinic acid and pathogens. In : INTERNATIONAL SYMPOSIUM ON THE MOLECULAR GENETICS OF PLANT-MICROBE INTERACTIONS, 5. Interlaken, 1990. Proceedings. Dordrecht., Kluwer Academic Publishers, 1991. 432-439p.

MILNE, R.G. An electron microscope study of tomato spotted wilt virus in sections of infected cell and negative stain preparations. Journal of General Virology, London, 6 (2) : 267-276, 1970.

MILNE, R.G. \& FRANCKI, R.I.B. Should tomato spotted wilt virus be considered as a possible member of the family Bunyaviridae ? Intervirology, Basel, 22 (2) : 72-76, 1984.

MOHAMED, N.A. Isolation and characterization of subviral structures from tomato spotted wilt virus. Journal of General Virology, London, 53 (1) : 197-206, 1981.

MOHAMED, N.A.; RANDLES, J.W.; FRANCKI, R.I.B. Protein composition of tomato spotted wilt virus. Virology, New York, 56 (1) : 12-21, 1973.

MURASHIGE , T. \& SKOOG, F. A revised medium for rapid growth and bioassay with tobacco tissue culture. Physiologia Plantarum, Copenhagen, 15 (4) : 473497, 1962. 
NADASKA, M.; \& ENDELSKI, K. PAL e SDH-specific activity in elicitor treated callus cultures of Papower somminiferum $\mathrm{L}$. during a growth period. Biologia, Copenhagen, 46 (7) : 577-582, 1991.

NAGATA, T. \& TAKEBE, I. Cell wall regeneration and cell division in isolated tobacco mesophyll protoplasts. Planta, Berlin,92 (2) : 301-308, 1970.

NOGUEIRA, N.L. \& SILVA, D.M. Autoradiographic localization of the synthetic sites of tomato spotted wilt virus and potato virus Y. Energia Nulcear $e$ Agricultura, Piracicaba, 6 (2) : 71-81, 1982.

NOGUEIRA, N.L.; SILVA, D.M.; MERZEL, J. Exame ao microscópio eletrônico de citoradiografía de follhas de fumo afetadas pelo virus "vira-cabeça" do tomateiro e do “anel do pimentão". Revista de Agricultura, Piracicaba, 47 (3,4) : 197-198, 1972.

NOORDAM, D. Identification of plant viruses : methods and experiments. Wageningen, Pudoc Press. 1973. 207p.

OBANNI, M.; HIPSKIND, J.; TSAI, C.Y.; NICHOLSON, R.L. \& DUNKLE, L.D. Phenylpropanoid accuroulation and sympton expression in the lethal leaf spot mutant mayze. Physiology and Molecular Plant Pathology, New York, 44 (5) : 379-388, 1994.

OBI, T.U. \& McCULLOUGH, K.C. Identification of epitope expression on the intemal proteins of ninderpest virus which is dependent upon virion maturation events. Journal of Virological Methods, Amsterdam, 41 (1) : 113-124, 1993.

OTSUKI, Y.; SHIMOMURA, T.; TAKEBE, T. Tobacco mosaic vinus multiplication and expression of the $\mathbf{N}$ gene in necrotic responding tobacco varieties. Virology, New York, 50 (2) : 45-50, 1972. 
PANG, S.Z.; SLIGHTOM, J.L.; GONSALVES, D. The biological properties of a distinct tospovirus and sequence analysis of its SRNA. Phytopathology, Lancaster, 83 (7) : 728-733, 1993.

PATTERSON, R.G.; SCOTT, S.J.; GERGERICH, R.C. Resistance in 2 Lycopersicon species to an Arkansas isolate of tomato spotted wilt virus. Euphytica, Wageningen, 43 (1-2) : 173-178, 1989.

PEBERDY, J.F. Fungal protoplasts : isolation, reversion and fusion. Annual Review of Microbiology, Oxford, 33 : 21-39, 1979.

PETERS, D.; ÁVILA, A.C. de; KITAIMA, E.W.; RESENDE, R de O.; de HAAN, P.; GOLDBACH, R. An overview of tomato spotted wilt virus. In : VIRUSTHRIPS-PLANT INTERACTIONS OF TSWV. Beltsville, 1991.

Proceerlings of USDA workshop, Springfield, National Technology Infomation Service, 1991, pp.1-14

PIRT, S.J. Principles of Microbe and Cell Cultivation. $2^{\mathrm{a}}$ ed.. Oxford, Blackwell Scientific Publishers, 1975. 274p.

PIRT, S.J. \& KUROWSKI, W.M. An extension of the theory of the chemostat with feedback of organisms. Its experimental realisation with a yeast culture. Journal of General Microbiology, London, 63 (3) : 357-366, 1970.

POWER, J.B.; CUMMINGS, S.E.; COCKING, E.C. Fusion of isolated plant protoplasts. Nature, London, 225 (10) : 1016-1018, 1970.

PRITCHARD, R.H. \& TEMPEST, D.W. Growth : Cell and Populations. In : MANDELSTAM, J.; McQUILLEN, K.; DAWES, I.W. eds. Biochemistry of bacterial growth. $3^{\mathrm{a}}$ ed. Oxford, Blackwell Scientific Publications, 1982. cap.2, p.99-123. 
QUECINI, V.M.; SILVA, D.M.da; LOPES, M.L.; PACHECO, F.T.H. Efeitos do vírus do vira-cabeça do tomateiro (VVCT) e de virazole sobre a cinética de crescimento de protoplastos do mesófilo de fumo. In : CONGRESSO BRASILEIRO DE FITOPATOLOGLA, 27, Itajaí, 1994. Resumo dos Trabalhos, Fitopatologia Brasileira, Brasília, 19 (suplemento) : 313, 1994.

RAJ, S.K.; AMINUDDIN; ASLAM, M.; SINGH, B.P. Elimination of eggplant mottled crinckle virus using virazole in explant cultures of Solanum melanogena L.. Indian Journal of Experimental Botany, New Delhi, 29 (6) : 594-595, 1991.

RAO, R.D.V.J.P.; CHAKRABORTY, S.K.; RAJESWARI, R.; REDDY, A.S. Occurence of tomato spotted wilt virus in cowpea (Vigna unguiculata (L.) Warp.); chili (Capsicum annum L.) and brinjal (Solanum melanogena L.). Indian Journal of Plant Protection, New Delhi, 15 (1) : 117-119, 1987.

REDDY, B.B.; HADDEN, C.H.; BOST, S.C. NEWMANN, M.A. First report of tomato spotted wilt virus in Tennesse. Plant Disease, Saint Paul, 71 (4) : 376, 1987.

REDDY, D.V.R; WIGHTMAN, J.A.; BESHEAR, R.J.; HIGHLAND, B.; BLACK, M.; SREENIVASUTU, P.; DWIVEDI, S.L.; DEMSK, J.W.; McDONALD, D.M; SMITH Jr. J.W.; SMITH, D.H. Bud Necrosis : a disease of groundnut cause by tomato spotted wilt virus. Information Bulletin no 31. Patancheru; ICRISAT, 1991. 20p.

REIMERS, P.J.; GUO, A.; LEACH, J.E. Increased activity of a cationic peroxidase associated with an incompatible interaction betwen Xanthomonas oryzae pv oryzae and rice (Oryza sativa). Plant Physiology, Rockville, 99 (3) : 1044-1050, 1992.

RESENDE, R. de O. Generation and characterization of mutants of tomato spotted wilt virus. Wageningen,1993.115p.( Doutorado - Landboumuniversiteit te Wageningen). 
ROSEMBERG, M.; MENANCIO, D.I.; HYMOWITZ, T. Isozymes as predictors of ploidy level in Glycine tabacina (Labill.) Benth.. Soybean Genetics Newsletter, Kew, $14: 267: 268,1987$.

SAKAGUCHI, S.; KATAMINE, N.; YAMAHOUCHI, K.; KISHIKAWA, M.; MORIUCHI, R.; YASUKAWA, N.; DOI, T.; MIYAMOTO, T. Kinetics of infectivity are dissociated from PrP accumulation in salivary glands of Creutzfeldt-Jakob disease agent-inoculated mice. Journal of General Virology, London, 74 (10) : 2117-2123, 1993.

SANDER, E. \& MERTES, G. Use of protoplasts and separate cells in plant virus research. Advances in Virus Research, San Diego, 29 : 215-259, 1984.

SAXEMA, P.K.; FOWKE, L.C.; KING, J. An efficient procedure for isolation of nuclei from plant protoplasts. Protoplasma, Berlin, 128 (1) : 184-189, 1985.

SCHENK, R.U. \& HILDEBRANDT, A.C. Production of protoplasts from plant cells in liquid culture using purified commercial cellulases. Crop Science, Ames, 9 (4) : 629-631, 1969.

SCHUSTER, G.L. \& HALLIWELL, R.S. Six new hosts of tomato spotted wilt virus in Texas. Plant Disease, Saint Paul, 78 (1) : 100, 1994.

SCHWIMMER, S. \& BALLS, A.K. Isolation and properties of crystalline $\alpha$-amylase from germmated barley. Journal of Biological Chemistry, Baltimore, 179 (1) : 1063 - 1069, 1949.

SEEVERS, P.M.; DALY, J.M.; CATEDRAL, F.F. The role of peroxidase isozymes in resistance to wheat stem nust disease. Plant Physiology, Rockville, 48 (3) : 353$360,1971$.

SEGEL, L.A. Modeling dynamic phenomena in molecular and cellular biology. $1^{\text {a }}$ ed. Cambridge, Cambridge University Press, 1984. 298p. 
SEHGAL, O.P. Pathogenesis-related proteins in lima bean leaves infected with tobacco ningspot virus and their distribution within and around local lesions. Plant Cell Reports, New York, 12 (1) : 55-59, 1992.

SELA, I. Plant-virus interactions related to resistance and localization of viral infections. Advances in Virus Research, SanDiego, 26 : 201-237, 1981.

SHARMA, J.P. \& CHAWLA, H.S. Ribonuclease isozyme at early germination stages in leaf-rust resistant isolines of wheat. Current Science, Uttar Pradesh, 58 (3) : 144-145, 1989.

SHAW, C.R. Electrophoretic variation in enzymes. Science, New York, 149 (3687) : 936-943, 1965.

SHAW, J.G. Early events in plant virus infections. In : DAVIES, J.W. ed. Molecular plant virology. vol II (replication and gene expression). Boca Raton, CRC Press Inc., 1985. 493p.

SHEPARD, J.F. Regeneration of plants from protoplasts of potato virus X-infected tobacco leaves. Virology, London, 78 (1) : 261-266, 1977.

SHERIF, S.E.; El-GHAMRY, M.A.; MOSTAFA, E.E. Oxidative enzymes in wheat cultivars inoculated with Erysiphe graminis f.sp. tritici. Journal of Agricultural Science, Assiut, 20 (3) : 273-278, 1989.

SIDWELL, R.W.; MUFFMANN, J.H.; BARNETT, B.B.; PIFAT, D.Y. In vitro and in vivo phlebovirus inhibition by ribavirin. Antimicrobial Agents and Chemotherapy, Washington, 32 (3) : 331-336, 1989.

SIMPKINS, I.; WALKEY, D.G.A.; NEELY, H.A. Chemical suppression of virus in cultured plant tissue. Annals of Applied Biology, Reading, 99 (2) : 161-169, 1981. 
SILVA, D.M. \& NOGUEIRA, N.L. Autoradiografia e microscopia eletrônica na determinação do local de sintese do vírus "vira-cabeça"do tomateiro. In : CONGRESSO BRASILEIRO DE BIOLOGIA CELULAR, 2.; COLÓQUIO BRASILEIRO DE MICROSCOPIA ELETRÔNICA, 7., Rio de Janeiro, 1980. Resumos. p.64-65.

SMEE, D.F.; COOMBS, J.; HUFPMANN, J.H.; HUGGINS, J.W.; SIDWELL, R.W. Combination chemotherapy of Punta Toro virus infections in mice using ribavirin and 7-thia-8-oxoguanosine. Antiviral Chemistry and Chemotherapy, Detroit, 2 (2) : 93-97, 1991.

SOCK, J.; ROHRINGER, R; KANG, Z. Extracellular $\beta$-1,3-glucanase in stem rust affected and abiotically stressed wheat leaves. Immunocythochemical localization of the enzime and detection of multiple forms in gels by activity staining with dye-labeled laminanin. Plant Physiology, Rockville, 94 (3) : 1376-1389, 1990.

STANBURY, P.F. \& WHITAKER, A. eds Principles of fermentation technology. $2^{\mathrm{a}}$ ed. Oxford, Pergamon Press, 1986. 255p.

STREETER, D.G.; WITKOWSKI, J.T.; KHARE, G.P.; SIDWELL, RW.; BAUER, R.J.; ROBINS, R.K.; SIMON, L.N. Mechanism of action of $1-\beta-D-$ ribofuranosyl-1,2,4triazole- 3-carboxamide (virazole), a new broad spectrum antiviral agent. Proceedings of the Academy of Sciences of the United States of America, Washington, 70 (2) : 1174-1178, 1973.

TAKEBE, I. The use of protoplasts in plant virology.Annual Review of Microbiology, Oxford, 13 : 105-125, 1975.

TAS, P.W.L.; BOERJAN, M.L.; PETERS, D. The structural proteins of tomato spotted wilt virus. Netherlands Journal of Plant Pathology, Wageningen, 83 (1) :61-72, 1977. 
TAVANTZIZ, S.M. Coat-protein and protease activity as in vitro translation products of potato carlavirus mRNA. Archives of Virology, New York, 120 (3/4) : 241-252, 1991.

TEMPLAAR ,M. J.\& JONES, M.G.K. Fusion characteristics of plant protoplasts in eletric fields. Planta, Berlin, 165 (2) : 205-216, 1985.

THEODOROPOULOS, P.A. \& ROUBELAKIS ANGELAKIS, K.A. Progress in leaf protoplast isolation and culture from vinus-free axenic shoot cultures of Vitis vinifera L.. Plant Cell, Tissue and Organ Culture, Dordrecht, 20 (1) : 15-23, 1990.

TOUSSAINT, A.; KUMMERT, J.; MAROQUIN, C.; LEBRUN, A.; ROGGEMANS, J. Use of virazole $\mathbf{R}$ to eradicate odontoglossum ringspot virus from in vitro cultures do Cymbidium Sw.. Plant Cell, Tissue and Organ Culture, Amsterdam, 32 (3) : 303-309, 1993.

TRAD, J.; PENA, L.; SERRA, M.T.; LOPES-ABELLA, D.; DIAZ-RUIZ, J.R. Properties of two pepper isolates of tomato spotted wilt virus (TSWV) : a serious problem in Spain. In : CONFERENCE ISHS VEGETABLE VIRUS WORKING GROUP, 7., Athens, Greece, July 12-16, 1992. Recent Advances in Vegetable Virus Research. Volos, Ores Publishing, 1992. p6365.

TSIQUAYE, K.N. \& BARNARD, J. Chemical desinfection of duck hepatitis B virus : a model for inactivation of infectivity of hepatitis B virus. Journal of Antimicrobial Chemotherapy, London, 32 (3), 313-323, 1993.

TSUDA, S.; HANADA, K.; HIDAKA, S.; MINOBE, Y.; KAMEYA-IWAKI, N.; TOMARU, K. The presence of three pairs of possibly complementary RNA species in isolated nucleocapsid material of tomato spotted wilt virus. Annals of the Phytopathological Society of Japan, Tokyo, 58 (3) : 393-404, 1992. 
ULRICH, T.H.; CHOWDHURY, J.B.; WIDHOLM, J.M. Callus and root formation from mesophyll protoplasts of Brassica rapa. Plant Science Letters, Amsterdam, 19 (2) : 347.354,1980.

URITANI, I. Protein changes in diseased plants. Annual Review of Phytopathology, Palo Alto, 9 : 211-234, 1971.

VAIRA, A.M.; LISA, V.; LUISONI, E. The spread of two strams of tomato spotted wilt virus in Liguria. Informatore Fitopatològico, Torino, 42 (2) : 56-63, 1992.

VAIRA, A.M.; ROGGERO, P.; LUISONI, E.; MASENGA, V.; MILNE, R.G.; LISA, V. Characterization of two tospovirus in Italy : tomato spotted wilt vinus and impatiens necrotic spot. Plant Pathology, London, 42 (4) : 530-542, 1993.

VALLEJOS, C.E. Enzyme activity staining. In : TANKSLEY, S.P. \& ORTON, T.J. eds. Isozyme in plant genetics and breeding. New York, Elsevier Publishers, 1983. p.469-516, vol.A.

VERKLEIJ, F.N. \& PETERS, D. Characterization of defective forms of tomato spotted wilt virus. Journal of General Virology, London, 64 (2) : 677-686, 1983.

VOS, P.; JAEGLE, M.; WELLINK, J.; VERVER, J.; EGGEN, R.; KAMMEN, A .van; GOLDBACH, R.W. Infectious RNA transcripts derived from full length DNA copies of the genomic RNAs of cowpea mosaic virus. Virology, New York, 165 (1) : 33-41, 1988.

WAGIH, E.E. Amylase activity may play a role in the "Pathosmosis" throught to develop in areas of virus localization in plants. Journal of Phytopathology, Berlin, 134 (1) : 22-26, 1992.

WAGIH, E.E. \& COUTTS, R.H.A. Similarities in the soluble profiles of leaf tissue following either a hypersensitive reaction to vinus infection or plasmolysis.

Plant Science Letters, Amsterdam, 21 (1) : 61-70, 1981. 
WAGIH, E.E. \& COUTTS, R.H.A. Peroxidase, polyphenoloxidase and ribonuclease in tobacco necrosis virus infected or mannitol osmotically stressed cowpea and cucumber tissue. 1.Quantitative alterations. Phytopathologische Zeitschrift, Berlin, 104 (1) : 1-12, 1982a.

WAGIH, E.E. \& COUTTS, R.H.A. Peroxidase, polyphenoloxidase and ribonuclease in tobacco necrosis virus infected or mannitol osmotically stressed cowpea and cucumber tissue. 2.Qualitative alterations. Phytopathologische Zeitschrift, Berlin, 104 (1) : 124-137, $1982 \mathrm{~b}$.

WAGIH, E.E. \& COUTTS, R.H.A. Comparison of virus-elicited and other stresses on the soluble protein fraction of cucumber cotyledons. Phytopathologische Zeitschrift, Berlin, 104 (3) : 364-374, 1982c.

WAGIH, E.E.; RAFTOPOULOS, A.E.; ARCHER, S.A.; COUTTS, R.H.A. Characterization of an apparently novel soluble protein fraction found in pathogen and osmotically-stressed cucumber cotyledons. Phytopathologische Zeitschrift, Berlin, 107 (3) : 233-243, 1983.

WALLIN, A.; GLIMELIUS, K.; ERICKSSON, T. The induction of aggregation and fusion of Daucus carota protoplasts by polyethylene glycol. Zeitschrift fur Pflanzenphysiologie, Berlin, 74 (1) : 64-80, 1974.

WANG, M.; MITCHELL, C.J.; HU, J.S.; GONSALVES, D.; CALISTER, C.H. Determination of whether tomato spotted wilt virus replicates in Toxonhynchites amboenensis mosquitoes and the relatedness of this virus to phleboviruses (Family Bunyaviridae). Intervirology, Basel, 33 (1) : 32-40, 1992.

WEISS, R.C. \& DOSTROM-RAM, T. Inhibitory effects of ribavirin alone or combined with human $\alpha$-interferon on feline infctious peritonitis virus replication in vitro. Veterinary Microbiology, Amsterdam, 20 (3) : 255-265, 1989. 
WEISS, R.C.; COX, N.R.; BOUDREAUX, M.K. Toxicologic effects of ribavirin in cats. Journal of Veterinary Pharmacology and Therapeutics, London, 16 (3) : 301-316, 1993.

WELLINK, J.; LENT, J.W.M. van; VERVER, J.; SIJEN, T.; GOLDBACH, R.; KAMMEN, A.van The cowpea mosaic virus mRNA-encoded $48 \mathrm{Kda}$ protein is responsible for induction of tubular structures in protoplasts. Journal of Virology, Washington, 67 (6) : 3660-3664, 1993.

WESTPHAL, L. \& WRICKE, G. Genetic and linkage analysis of isozyme loci in Daucus carota L.. Euphytica, Wageningen, 56 (3) : 259-267, 1991.

WUKAMP, I.; LENT, J. van ; KORMELINK, R.; GOLDBACH, R.; PETERS, D. Virus-vector interactions during the transmission of tospovirus by thrips. Proceedings of Experimental and Applied Entomology, Amsterdam, 4 (2) : 193-199, 1993.

WOOD, K.R. Tissue culture methods in phytopathology. I - viruses. In : DIXON, R.A. ed. Plant cell culture : a practical approach. $2^{\mathrm{a}}$ ed. Oxford, IRL Press, 1987. cap. 9, 193-214. (Practical Approach Series)

YALPANI, N.; ENYEDI, A.J.; LEON, J.; RASKIN, I. Ultraviolet light and ozone stimulate accumulation of salicylic acid, pathogenesis-related proteins and virus resistance in tobacco. Planta, Berlin, 193 (3) : 373-376, 1994.

YALPANI, N.; SHUALAEV, V.; RASKIN, I. Endogenous salicylic acid levels correlate with accumulation of pathogenesis-related proteins and virus resistance in tobacco. Phytopathology, Lancaster, 83 (7) : 702-708, 1993.

YANIV, H. \& GILWARD, C. Aromatic biosynthesis. XIV-5-dehydroshikimic reductase. Journal of Biological Chemistry, Baltimore, 213 (2) : 787-795, 1955. 
YASHIKAWA, M.; NAKAMURA S.; EHARA, Y. General properties of pathogenesis-related proteins produced in cowpea leaves infected with cucumber mosaic vinus. Annals of the Phytopathological Society of Japan, Tokyo, 59 (2) : 196-199, 1993.

YOSHIDA, F.; YANAME, T.; NAKAMOTO, K. Fed-batch hydrocarbon fermentation with colloidal emulsion feed. Biotechnology and Bioengineering, New York, 15 (2) : 257-270, 1973.

YOUNG, M.J.; LARKIN, P.J.; MILLER, W.A.; WATERHOUSE, P.M.; GERLACH, W.L. Infection of Triticum monococcum protoplasts with barley yellow dwarf virus. Journal of General Virology, London, 70 (8) : 2245$2251,1989$.

YOU-YING, F.; SHI-RONG, J.; YUN, L. Plant regeneration from mesophyll protoplast culture of cabbage (Brassica oleracea var "capitata"). Theoretical and Applied Genetics, London, 71 (4) : 495-499, 1985.

ZIMMER R.C. \& HABER, S. First report of tomato spotted wilt virus in Manitoba and of Lathyrus satirus as a host. Plant Disease, Saint Paul, 76 (7) : 753, 1992.

ZIMMERMANN, U.\& SCHEURICH, P. High frequency fusion of plant protoplasts by electric fields. Planta, Berlin, 5 (1) : 26-32, 1981. 


\section{APÊNDICE 1}


Soluções usadas para obtenção e cultivo de protoplastos

1. Solução-Mãe Concentrada 10 vezes (solução de macroelementos)

$\begin{array}{ll}\mathrm{NaH}_{2} \mathrm{PO}_{4} \text { (Reagen) } & 12,50 \mathrm{mM} \\ \mathrm{KNO}_{3} \text { (Reagen) } & 0,25 \mathrm{M} \\ \left(\mathrm{NH}_{4}\right)_{2} \mathrm{SO}_{4} \text { (Reagen) } & 10,00 \mathrm{M} \\ \mathrm{CaCl}_{2} .2 \mathrm{H}_{2} \mathrm{O} \text { (Riedel-de Haën) } & 10,00 \mathrm{M} \\ \mathrm{H}_{2} \mathrm{O} \text { deionizada } & \text { q.s.p. } 1000 \mathrm{~mL}\end{array}$

2. Sulfato de Magnésio Heptahidratado 10 vezes concentrado
$\mathrm{MgSO}_{4}$. $7 \mathrm{H}_{2} \mathrm{O}$ (Merck)
$10,00 \mathrm{mM}$
$\mathrm{H}_{2} \mathrm{O}$ deionizada
q.s.p. $100 \mathrm{~mL}$

3. Solução de Microelementos 10 vezes concentrada
$\mathrm{MnSO}_{4}$. $2 \mathrm{H}_{2} \mathrm{O}$ (Merck)
$0,50 \mathrm{mM}$
$\mathrm{H}_{3} \mathrm{BO}_{3}$ (Cinética Química)
$0,50 \mathrm{mM}$
$\mathrm{ZnSO}_{4}, 7 \mathrm{H}_{2} \mathrm{O}$ (Reagen)
$0,07 \mathrm{mM}$
$\mathrm{H}_{2} \mathrm{O}$ deionizada
q.s.p. $100 \mathrm{~mL}$

4. Solução de Microelementos 100 vezes concentrada

$\begin{array}{ll}\mathrm{Na}_{2} \mathrm{MoO}_{4} \cdot 2 \mathrm{H}_{2} \mathrm{O} \text { (Merck) } & 0,100 \mathrm{mM} \\ \mathrm{CuSO}_{4} \text { (Merck) } & 0,015 \mathrm{mM} \\ \mathrm{CaCl}_{2} \cdot 6 \mathrm{H}_{2} \mathrm{O} \text { (Riedel-de Haën) } & 0,017 \mathrm{mM} \\ \mathrm{KI} \text { (Química Modema) } & 0,450 \mathrm{mM} \\ \mathrm{H}_{2} \mathrm{O} \text { deionizada } & \text { q.s.p. } 100 \mathrm{~mL}\end{array}$

5. Solução de Vitaminas

$\begin{array}{ll}\text { Ácido nicotínico (Merck) } & 0,080 \mathrm{mM} \\ \text { Tiamina-HCl (Merck) } & 0,300 \mathrm{mM} \\ \text { Piridoxina- } \mathrm{HCl} \text { (Merck) } & 0,050 \mathrm{mM} \\ \text { Mesoinositol (Merck) } & 4,600 \mathrm{mM} \\ \mathrm{H}_{2} \mathrm{O} \text { deionizada } & \text { q.s.p. } 100 \mathrm{~mL}\end{array}$


6. Soluções de Hormônios Vegetais

2,4 D (Sigma)

ANA (Sigma)

6-BAP (Sigma)

7. Solução de Fe-EDTA

$\mathrm{Na}_{2}$ EDTA (Química Modema)

$\mathrm{FeSO}_{4} \cdot 7 \mathrm{H}_{2} \mathrm{O}$ (Mallinderodt)

$\mathrm{H}_{2} \mathrm{O}$ deionizada
$2 \mathrm{mg} / 100 \mathrm{~mL}$ de água deionizada

$2 \mathrm{mg} / 100 \mathrm{~mL}$ de água deionizada

$2 \mathrm{mg} / 100 \mathrm{~mL}$ de água deionizada

Obs.: Todas as soluções mencionadas foram feitas com água destilada e, quando mencionado, deionizada.

Foram mantidas em local fresco e protegido da luz direta.

\section{Meios de Cultura para Protoplastos}

1. Meio de Maceração

Solução-Mãe $10 \mathrm{x}$ concentrada

$10 \%$

Sol. $\mathrm{MgSO}_{4} \cdot 7 \mathrm{H}_{2} \mathrm{O} 10 \times$ concentrada

$1 \%$

Sol. Fe-EDTA

$0,5 \%$

Sol. Microelementos $10 \mathrm{x}$ concentrada

$1 \%$

Sol. Microelementos $100 \mathrm{x}$ concentrada

$0,1 \%$

Sol. Vitaminas $10 \times$ concentrada

$1 \%$

Manitol

$0,5 \mathrm{M}$

Sol. 2,4 D

$1 \%$

Sol. ANA

$0,5 \%$

Sol. 6-BAP

$0,5 \%$

$\mathrm{H}_{2} \mathrm{O}$ deionizada

q.s.p. $1000 \mathrm{~mL}$

Obs. : As quantidades estão apresentadas como porcentagens de volume (v/v), exceto quando indicado outra unidade. 
2. Meio de Cultura (ou Meio Completo)

idem ao anterior, apenas acrescentando-se :

Sacarose (Ecibra)

$30 \mathrm{mM}$

Glicose (Ecibra)

$28 \mathrm{mM}$

$\mathrm{H}_{2} \mathrm{O}$ deionizada

q.s.p. $1000 \mathrm{~mL}$

\section{Meio Sólido}

idem ao anterior, apenas acrescentando :

Ágar (Difco)

$1 \%(\mathrm{p} / \mathrm{v})$

$\mathrm{H}_{2} \mathrm{O}$ deionizada

q.s.p. $1000 \mathrm{~mL}$

Obs. : Todos os meios tiveram o pH ajustado para 5,8. Foram mantidos em frascos escuros e sob refrigeração constante.

\section{Enzimas Hidrolíticas para Obtenção de Protoplastos}

Para cada $10 \mathrm{~mL}$ de meio de maceração (aproximadamente $1 \mathrm{~g}$ de material vegetal) foram utilizadas :

Celulase (Yakult Onozuka R10)

Driselase (Kyowa Hakko Kogyo)

Macerozima (Serva obtida de Rhizopus sp.)

Pectinase (Sigma obtida de $A$. niger)

Hemicelulase (Yakult)
240 unidades

3 unidades

6 unidades

70 unidades

6 unidades

Obs.: A solução de enzimas dissolvida no meio de maceração foi esterilizada por filtração a vácuo com filtros de nitrocelulose com poros de $0,22 \mu \mathrm{m}$ de diâmetro (Milipore). Após a maceração do material por 16 horas, a solução de enzimas foi retirada e refiltrada em nitrocelulose com poro de $0,45 \mu \mathrm{m}$ (Milipore) e conservada em congelador a $-20^{\circ} \mathrm{Cpara}$ posterior reutilização, quando o procedimento de esterilização por filtragem foi repetido. 
APÊNDICE 2 
Tampão para a Extração de Proteínas Armazenadas sob Congelamento

$\begin{array}{ll}\text { TRIS - } \mathrm{HCl} \text { (Synth) } & 63 \mathrm{mM} \\ \text { 2- Me (Merck) } & 2 \%(\mathrm{v} / \mathrm{v}) \\ \text { Glicerol (Merck) } & 10 \%(\mathrm{v} / \mathrm{v})\end{array}$

Obs. : $О$ pH foi ajustado para 6,8 e o tampão foi filtrado e mantido em frasco escuro a $4^{\circ} \mathrm{C}$. 


\section{APÊNDICE 3}


Tabela 7 : Logarítmo do número de protoplastos viáveis/ $\mathrm{mL}$ presentes no cultivo em suspensão obtidos através da contagem direta ao microscópio óptico com Câmara de Neubauer e parâmetros estatísticos da correlação linear com transformação logarítmica.

\begin{tabular}{|c|c|c|c|c|}
\hline dia & Sadio & Sadio+Ribavirina & Doente & Doente+Ribavirina \\
\hline $\mathbf{0}$ & $0,85 \cdot 10^{-6}$ & $3,45 \cdot 10^{-7}$ & $5,50 \cdot 10^{-6}$ & $3,45 \cdot 10^{-6}$ \\
\hline $\mathbf{1}$ & $2,34 \cdot 10^{-5}$ & $9,84 \cdot 10^{-6}$ & $1,19 \cdot 10^{-5}$ & $7,86 \cdot 10^{-6}$ \\
\hline $\mathbf{3}$ & $3,47 \cdot 10^{-5}$ & $1,57 \cdot 10^{-5}$ & $1,46 \cdot 10^{-5}$ & $1,33 \cdot 10^{-5}$ \\
\hline $\mathbf{5}$ & $5,59 \cdot 10^{-5}$ & $1,95 \cdot 10^{-5}$ & $4,19 \cdot 10^{-5}$ & $1,53 \cdot 10^{-5}$ \\
\hline $\mathbf{7}$ & $1,78 \cdot 10^{-4}$ & $9,24 \cdot 10^{-5}$ & $1,30 \cdot 10^{-4}$ & $8,12 \cdot 10^{-5}$ \\
\hline $\mathbf{9}$ & $2,99 \cdot 10^{-3}$ & $1,96 \cdot 10^{-4}$ & $2,37 \cdot 10^{-3}$ & $1,39 \cdot 10^{-4}$ \\
\hline $\mathbf{1 1}$ & $7,79 \cdot 10^{-2}$ & $1,77 \cdot 10^{-3}$ & $5,70 \cdot 10^{-2}$ & $1,43 \cdot 10^{-5}$ \\
\hline $\mathbf{1 3}$ & $1,05 \cdot 10^{-1}$ & $1,31 \cdot 10^{-3}$ & $1,24 \cdot 10^{-1}$ & $2,43 \cdot 10^{-2}$ \\
\hline $\mathbf{1 5}$ & $2,58 \cdot 10^{-1}$ & $1,40 \cdot 10^{-2}$ & $3,35 \cdot 10^{-1}$ & $5,11.10^{-2}$ \\
\hline $\mathbf{1 7}$ & $2,67 \cdot 10^{-1}$ & $2,89 \cdot 10^{-2}$ & $4,60 \cdot 10^{-1}$ & $6,27 \cdot 10^{-2}$ \\
\hline $\mathbf{1 9}$ & $8,14 \cdot 10^{-1}$ & $3,06 \cdot 10^{-1}$ & $9,13 \cdot 10^{-1}$ & $3,02 \cdot 10^{-2}$ \\
\hline $\mathbf{A}$ & $-5,455929161$ & $-5,89408069$ & $-5,757377828$ & $-5,895730411$ \\
\hline $\mathbf{B}$ & 0,309896207 & 0,265067952 & 0,334226375 & 0,27177719 \\
\hline $\mathbf{s}$ & 2,073092 & 1,757334 & 2,1774073 & 1,828729 \\
\hline $\mathbf{s}^{2}$ & 4,297714 & 3,0882249 & 4,7411027 & 3,344251 \\
\hline $\mathbf{n}$ & $11 \times 7$ & $11 \times 7$ & $11 \times 7$ & $11 \times 7$ \\
\hline
\end{tabular}

A representa o termo independente da equação, $\mathbf{B}$ a tangente do ângulo $\alpha$ formado pela reta com o eixo $\mathrm{x}, \mathbf{n}$ representa o número de dados analisados estatisticamente multiplicado pelo número de repetições, $s$ representa o desvio padrão da população e $\mathrm{s}^{2}$ a variância estatística da população. A equação de regressão utilizada foi : $\log \mathbf{y}=\mathbf{A}+\mathbf{B x}$, onde $\mathbf{y}=$ número de protoplastos viáveis / $\mathrm{mL}$ e $\mathbf{x}=$ tempo (dias). 
Tabela 8 : Comprimento da corda $\mathbf{W}(\mathrm{cm})$ formada pelos protoplastos precipitados no cultivo de suspensão e parâmetros estatísticos da correlação linear .

\begin{tabular}{|c|c|c|c|c|}
\hline dia & Sadio & Sadio+Ribavirina & Doente & Doente+Ribavirina \\
\hline $\mathbf{7}$ & 2,913 & 3,524 & 2,482 & 3,167 \\
\hline $\mathbf{9}$ & 4,133 & 4,203 & 3,442 & 3,774 \\
\hline $\mathbf{1 1}$ & 4,542 & 5,134 & 4,088 & 4,490 \\
\hline $\mathbf{1 3}$ & 4,958 & 5,390 & 4,533 & 4,960 \\
\hline $\mathbf{1 5}$ & 5,490 & 5,380 & 5,020 & 4,950 \\
\hline $\mathbf{1 7}$ & 6,810 & 5,700 & 6,590 & 5,158 \\
\hline $\mathbf{1 9}$ & 7,351 & 5,920 & 7,400 & 5,420 \\
\hline $\mathbf{A}$ & $-1,330246088$ & $-10,57188111$ & 1,165557655 & $-9,927566806$ \\
\hline $\mathbf{B}$ & 2,771248757 & 4,680801410 & 2,4688155127 & 5,028132699 \\
\hline $\mathbf{s}$ & 1,536020034 & 0,861746372 & 1,7227754600 & 0,813679795 \\
\hline $\mathbf{s}^{2}$ & 2,359397546 & 0,7426068090 & 2,9679552860 & 0,662074809 \\
\hline $\mathbf{n}$ & $\mathbf{7 \times 7}$ & $7 \times 7$ & $7 \times 7$ & $7 \times 7$ \\
\hline
\end{tabular}

A representa o termo independente da equação, B a tangente do ângulo $\alpha$ formado pela reta com o eixo $\mathbf{x}, \mathbf{n}$ representa o número de dados analisados estatisticamente multiplicado pelo número de repetições, $s$ representa o desvio padrão da população e $\mathrm{s}^{2}$ a variância estatística da população. A equação de regressão utilizada foi : $\mathbf{y}=\mathbf{A}+\mathbf{B x}$, onde $\mathbf{y}=$ comprimento da corda W (cm) e $\mathbf{x}=$ tempo (dias). 
Tabela 9 : Densidade óptica do cultivo medida em espectrofotômetro a $\lambda=490 \mathrm{~nm}$, descontando-se o valor da dispersão luminosa de acordo com NOORDAM (1973) e parâmetros estatísticos.

\begin{tabular}{|c|c|c|c|c|c|}
\hline$\overline{\text { Dia }}$ & Meio & Sadio & $\mathbf{S + R}$ & Doente & $\overline{\mathbf{D}+\mathbf{R}}$ \\
\hline $\mathbf{0}$ & 0,040 & 0,041 & 0,040 & 0,041 & 0,041 \\
\hline 1 & 0,040 & 0,079 & 0,112 & 0,100 & 0,131 \\
\hline 3 & 0,042 & 0,095 & 0,080 & 0,100 & 0,100 \\
\hline 5 & 0,040 & 0,141 & 0,094 & 0,098 & 0,098 \\
\hline 7 & 0,041 & 0,162 & 0,096 & 0,079 & 0,087 \\
\hline 9 & 0,040 & 0,200 & 0,095 & 0,080 & 0,097 \\
\hline 11 & 0,040 & 0,271 & 0,120 & 0,110 & 0,178 \\
\hline 13 & 0,044 & 0,300 & 0,142 & 0,055 & 0,138 \\
\hline 15 & 0,041 & 0,357 & 0,253 & 0,098 & 0,187 \\
\hline 17 & 0,040 & 0,387 & 0,241 & 0,087 & 0,186 \\
\hline \multicolumn{2}{|c|}{ sx } & 0,1203800 & 0,068493389 & 0,021892667 & 0,048547914 \\
\hline \multicolumn{2}{|c|}{$\mathrm{s}^{2} \mathrm{x}$} & 0,014491344 & 0,004691344 & 0,000479228 & 0,002356900 \\
\hline \multicolumn{2}{|c|}{$\overline{\mathbf{A}}$} & 0,038900287 & 0,047162032 & 0,080445829 & 0,071136145 \\
\hline \multicolumn{2}{|c|}{ B } & 0,02029626 & 0,00989357622 & 0,000537552 & 0,0065634388 \\
\hline \multicolumn{2}{|c|}{$\mathbf{r}$} & 0,904130096 & 0,851699065 & 0,144778233 & 0,797154291 \\
\hline \multicolumn{2}{|c|}{ sy } & \multicolumn{4}{|c|}{5,89632654} \\
\hline \multicolumn{2}{|c|}{$\mathbf{s}^{2} y$} & \multicolumn{4}{|c|}{34,76666667} \\
\hline
\end{tabular}

A representa o termo independente da equação, B a tangente do ângulo $\alpha$ formado pela reta com o eixo $x, s$ representa o desvio padrão da população e $s^{2}$ a variância estatística da população, para os valores de $\mathrm{x}$ e $\mathrm{y}$ analisados, onde $\mathrm{x}=$ densidade óptica a $\lambda=490 \mathrm{~nm}$, descontando-se a dispersão luminosa e $\mathbf{y}=$ tempo (dias). 
Tabela 10 : Análise de variância de regressões para os valores de densidade óptica do cultivo medida em espectrofotômetro a $\lambda=490 \mathrm{~nm}$, descontando-se o valor da dispersão luminosa de acordo com NOORDAM (1973) .

\begin{tabular}{|c|c|c|c|c|c|}
\hline \multicolumn{2}{|c|}{ Regressão } & S & S + R & D & D + R \\
\hline linear & $95 \%$ & $*$ & n.s. & n.s. & n.s. \\
\cline { 2 - 6 } & $99 \%$ & n.s. & n.s. & n.s. & n.s. \\
\hline logarítmica & $95 \%$ & n.s. & n.s. & n.s. & n.s. \\
\cline { 2 - 6 } & $99 \%$ & n.s. & n.s. & n.s. & n.s. \\
\hline exponencial & $95 \%$ & n.s. & n.s. & n.s. & n.s. \\
\cline { 2 - 6 } & $99 \%$ & n.s. & n.s. & n.s. & n.s. \\
\hline
\end{tabular}

Tabela 11 : Coeficiente de variação e intervalo de confiança para as contagens médias do logarítmo número de protoplastos viáveis / $\mathrm{mL}$ presentes no cultivo, para o material sadio.

\begin{tabular}{|c|c|c|c|c|}
\hline Dia & Contagem & I.C. (95\%) & I.C. (99\%) & C.V. (\%) \\
\hline $\mathbf{O}$ & $0,85 \cdot 10^{-6}$ & 0,16 a $2,86 \cdot 10^{-6}$ & 0,392 a $5,62 \cdot 10^{-6}$ & 4,32 \\
\hline $\mathbf{1}$ & $2,34 \cdot 10^{-5}$ & 1,30 a $4,36 \cdot 10^{-5}$ & 2,28 a $7,12 \cdot 10^{-5}$ & 6,27 \\
\hline $\mathbf{3}$ & $3,47 \cdot 10^{-5}$ & 1,45 a $5,48 \cdot 10^{-5}$ & 1,30 a $8,24 \cdot 10^{-5}$ & 3,26 \\
\hline $\mathbf{5}$ & $5,59 \cdot 10^{-5}$ & 3,57 a $7,60.10^{-5}$ & 0,81 a $10,36 \cdot 10^{-5}$ & 3,15 \\
\hline $\mathbf{7}$ & $1,78 \cdot 10^{-4}$ & 1,37 a $3,79 \cdot 10^{-4}$ & 2,99 a $6,55 \cdot 10^{-5}$ & 4,63 \\
\hline $\mathbf{9}$ & $2,99 \cdot 10^{-3}$ & 0,75 a $5,00 \cdot 10^{-3}$ & 1,78 a $7,76 \cdot 10^{-3}$ & 1,71 \\
\hline $\mathbf{1 1}$ & $7,79 \cdot 10^{-2}$ & 3,49 a $12,10.10^{-2}$ & 0,29 a $21,89 \cdot 10^{-2}$ & 1,13 \\
\hline $\mathbf{1 3}$ & $1,05 \cdot 10^{-1}$ & 0,25 a $5,33 \cdot 10^{-1}$ & 0,04 a $1,51 \cdot 10^{-1}$ & 1,75 \\
\hline $\mathbf{1 5}$ & $2,58 \cdot 10^{-1}$ & 1,24 a $4,56 \cdot 10^{-1}$ & 0,89 a $5,37 \cdot 10^{-1}$ & 3,82 \\
\hline $\mathbf{1 7}$ & $2,67 \cdot 10^{-1}$ & 1,30 a $4,69 \cdot 10^{-1}$ & 0,76 a $5,43 \cdot 10^{-1}$ & 1,09 \\
\hline
\end{tabular}


Tabela 12 : Coeficiente de variação e intervalo de confiança para as contagens médias do logarítmo do número de protoplastos viáveis / $\mathrm{mL}$ presentes no cultivo, para o material doente.

\begin{tabular}{|c|c|c|c|c|}
\hline Dia & Contagem & I.C. (95\%) & I.C. (99\%) & C.V. (\%) \\
\hline$\overline{0}$ & $0,55.10^{-6}$ & 0,02 a $1,56.10^{-6}$ & 0,04 a $3,23 \cdot 10^{-6}$ & 8,96 \\
\hline 1 & $1,19 \cdot 10^{-5}$ & 0,08 a $1,23 \cdot 10^{-5}$ & 0,05 a $1,56 \cdot 10^{-5}$ & 6,04 \\
\hline 3 & $1,14 \cdot 10^{-5}$ & 0,52 a $1,47.10^{-5}$ & 0,31 a $6,23.10^{-5}$ & 2,21 \\
\hline 5 & $4,19 \cdot 10^{-5}$ & 3,31 a $4,52 \cdot 10^{-5}$ & 1,47 a $6,98 \cdot 10^{-5}$ & 4,08 \\
\hline 7 & $1,30 \cdot 10^{-4}$ & 1,12 a $2,33 \cdot 10^{4}$ & 0,99 a $2,85.10^{-5}$ & 1,87 \\
\hline 9 & $2,37 \cdot 10^{-3}$ & 2,09 a $3,87.10^{-3}$ & 1,28 a $5,76 \cdot 10^{-3}$ & 2,31 \\
\hline 11 & $5,70 \cdot 10^{-2}$ & 3,56 a $6,81 \cdot 10^{-2}$ & 2,29 a $9,89 \cdot 10^{-2}$ & 3,10 \\
\hline 13 & $1,24 \cdot 10^{-1}$ & 1,01 a $2,08 \cdot 10^{-1}$ & 0,01 a $5,52.10^{-1}$ & 1,06 \\
\hline 15 & $3,35 \cdot 10^{-1}$ & 3,67 a $6,45 \cdot 10^{-1}$ & 0,76 a $6,37 \cdot 10^{-1}$ & 1,73 \\
\hline 17 & $4,11 \cdot 10^{-1}$ & 3,67 a $6,45 \cdot 10^{-1}$ & 1,16 a $7,43 \cdot 10^{-1}$ & 5,23 \\
\hline
\end{tabular}


Tabel a13 : Coeficiente de var iaçãoe inter vab de confiança par aas contagens médias do 1 gar ítmodo número de protopl astes viáveis / $\mathrm{mL}$ presentes no cultivo, par ao mater ialdoente tratado com ribavir ina

\begin{tabular}{|c|c|c|c|c|}
\hline Dia & Contagem & I.C. ( 95\%) & I.C. (99\%) & C.V. (\%) \\
\hline$\overline{0}$ & $0,34 \cdot 10^{-6}$ & 0,18 a $2,5410^{-6}$ & 0,31 a $3,85.10^{-6}$ & 12,17 \\
\hline 1 & $0,78 \cdot 10^{-5}$ & 0,14 a $2,98 \cdot 10^{-5}$ & 0,27 a $4,2810^{-5}$ & 4,17 \\
\hline 3 & $1,33 \cdot 10^{-5}$ & 0,87 a $3,53.10^{-5}$ & 0,22 a $4,83.10^{-5}$ & 5,11 \\
\hline 5 & $1,53 \cdot 10^{-5}$ & 0,69 a $3,73.10^{-5}$ & 0,19 a $5,03.10^{-5}$ & 3,63 \\
\hline 7 & $0,81 \cdot 10^{-4}$ & 0,15 a $3,17 \cdot 10^{-4}$ & 0,32 a $4,84.10^{-5}$ & 3,85 \\
\hline 9 & $1,39 \cdot 10^{-3}$ & 1,05 a $3,84.10^{-3}$ & 0,29 a $5,71.10^{-3}$ & 3,59 \\
\hline 11 & $1,43 \cdot 10^{-2}$ & 1,02 a $3,87 \cdot 10^{-2}$ & 0,28 a $5,74 \cdot 10^{-2}$ & 3,00 \\
\hline 13 & $2,43 \cdot 10^{-2}$ & 1,4 a $4,88 \cdot 10^{-2}$ & 0,18 a $6,75.10^{-1}$ & 6,71 \\
\hline 15 & $5,11 \cdot 10^{-2}$ & 2,33 a $7,89 \cdot 10^{-2}$ & 0,48 a $10,71 \cdot 10^{-1}$ & 4,33 \\
\hline 17 & $6,27 \cdot 10^{-2}$ & 2,56 a $9,45 \cdot 10^{-2}$ & 1,18 a $13,72 \cdot 10^{-1}$ & 2,19 \\
\hline 19 & $3,02 \cdot 10^{-1}$ & 2,01 a $4,89 \cdot 10^{-1}$ & 0,76 a $7,85.10^{-1}$ & 1,17 \\
\hline
\end{tabular}


Tabela 14 : Coeficiente de variação e intervalo de confiança para as contagens médias do logarítmo do número de protoplastos viáveis / $\mathrm{mL}$ presentes no cultivo, para o material sadio tratado com ribavirina.

\begin{tabular}{|c|c|c|c|c|}
\hline Dia & Contagem & I.C. ( 95\%) & I.C. (99\%) & C.V. (\%) \\
\hline $\mathbf{0}$ & $0,34 \cdot 10^{-6}$ & 0,18 a $2,57 \cdot 10^{-6}$ & 0,11 a $4,53 \cdot 10^{-6}$ & 12,17 \\
\hline $\mathbf{1}$ & $0,98 \cdot 10^{-5}$ & 0,12 a $3,21 \cdot 10^{-5}$ & 0,17 a $1,92 \cdot 10^{-5}$ & 4,17 \\
\hline $\mathbf{3}$ & $1,57 \cdot 10^{-5}$ & 0,24 a $4,17 \cdot 10^{-5}$ & 1,02 a $5,63 \cdot 10^{-5}$ & 5,11 \\
\hline $\mathbf{5}$ & $1,95 \cdot 10^{-5}$ & 0,14 a $3,28 \cdot 10^{-5}$ & 1,52 a $7,78 \cdot 10^{-5}$ & 3,63 \\
\hline $\mathbf{7}$ & $0,92 \cdot 10^{-4}$ & 0,14 a $3,23 \cdot 10^{-4}$ & 1,02 a $3,85 \cdot 10^{-5}$ & 3,85 \\
\hline $\mathbf{9}$ & $1,96 \cdot 10^{-3}$ & 0,40 a $4,33 \cdot 10^{-3}$ & 1,57 a $4,96 \cdot 10^{-3}$ & 3,59 \\
\hline 11 & $1,77 \cdot 10^{-2}$ & 0,59 a $2,13 \cdot 10^{-2}$ & 1,09 a $11,07 \cdot 10^{-2}$ & 3,00 \\
\hline 13 & $1,13 \cdot 10^{-2}$ & 1,05 a $3,48 \cdot 10^{-2}$ & 0,02 a $5,95 \cdot 10^{-1}$ & 6,71 \\
\hline 15 & $1,40 \cdot 10^{-2}$ & 1,13 a $3,49 \cdot 10^{-2}$ & 0,43 a $7,26 \cdot 10^{-1}$ & 4,33 \\
\hline 17 & $2,89 \cdot 10^{-2}$ & 1,54 a $3,18 \cdot 10^{-2}$ & 1,06 a $8,19 \cdot 10^{-1}$ & 2,19 \\
\hline 19 & $3,06 \cdot 10^{-1}$ & 1,56 a $3,89 \cdot 10^{-1}$ & 2,02 a $7,47 \cdot 10^{-1}$ & 1,17 \\
\hline
\end{tabular}

Tabela 15 : Coeficiente de variação e intervalo de confiança para as medidas médias do valor $\mathbf{W}(\mathrm{cm})$ do cultivo, para o material sadio.

\begin{tabular}{|c|c|c|c|c|}
\hline Dia & W (cm) & I.C. (95\%) & I.C. (99\%) & C.V. (\%) \\
\hline 7 & 2,913 & 0,466 a 5,360 & $-1,404$ a 7,230 & 19,43 \\
\hline 9 & 4,133 & 1,686 a 6,580 & $-0,184$ a 8,450 & 15,95 \\
\hline 11 & 4,542 & 1,971 a 7,113 & 0,510 a 8,574 & 9,48 \\
\hline 13 & 4,958 & 2,387 a 7,529 & 0,926 a 8,990 & 16,61 \\
\hline 15 & 5,490 & 1,187 a 9,793 & $-8,600$ a 9,793 & 4,64 \\
\hline 17 & 6,810 & 2,5733 a 8,240 & $-2,476$ a 7,863 & 10,01 \\
\hline
\end{tabular}


Tabela 16 : Coeficiente de variação e intervalo de confiança para as medidas médias do valor W (cm) do cultivo, para o material doente.

\begin{tabular}{|c|c|c|c|c|}
\hline Dia & W (cm) & I.C. (95\%) & I.C. (99\%) & C.V. (\%) \\
\hline 7 & 2,482 & $-0,089$ a 5,053 & $-1,835$ a 6,799 & 26,19 \\
\hline 9 & 3,442 & 0,871 a 6,013 & $-0,875$ a 7,759 & 20,79 \\
\hline 11 & 4,088 & 1,517 a 6,659 & $-0,228$ a 8,405 & 17,90 \\
\hline 13 & 4,533 & 1,962 a 7,104 & 0,216 a 8,850 & 17,12 \\
\hline 15 & 5,020 & 0,717 a 9,323 & $-9,069$ a 19,109 & 10,42 \\
\hline 17 & 6,590 & 1,533 a 8,491 & $-5,346$ a 18,385 & 12,37 \\
\hline
\end{tabular}

Tabela 17 : Coeficiente de variação e intervalo de confiança para as medidas médias do valor $\mathbf{W}(\mathrm{cm})$ do cultivo, para o material sadio tratado com ribavirina.

\begin{tabular}{|c|c|c|c|c|}
\hline Dia & W (cm) & I.C. (95\%) & I.C. (99\%) & C.V. (\%) \\
\hline 7 & 3,524 & 1,262 a 6,150 & $-0,166$ a 7,214 & 17,34 \\
\hline $\mathbf{9}$ & 4,203 & 1,838 a 6,568 & 0,174 a 8,232 & 17,42 \\
\hline 11 & 5,134 & 2,687 a 7,581 & 0,817 a 9,451 & 6,97 \\
\hline 13 & 5,389 & 2,819 a 7,961 & 0,617 a 10,163 & 8,79 \\
\hline 15 & 5,379 & 1,076 a 9,682 & $-8,710$ a 19,469 & 0,55 \\
\hline 17 & 5,700 & 2,768 a 6,413 & $-6,589$ a 17,321 & 3,71 \\
\hline 19 & 5,920 & 2,535 a 8,713 & $-7,893$ a 18,445 & 10,21 \\
\hline
\end{tabular}


Tabela 18 : Coeficiente de variação e intervalo de confiança para as medidas médias do valor W (cm) do cultivo, para o material doente tratado com ribavirina.

\begin{tabular}{|c|c|c|c|c|}
\hline Dia & W (cm) & I.C. (95\%) & I.C. (99\%) & C.V. (\%) \\
\hline 7 & 3,167 & 0,905 a 5,429 & $-0,523$ a 6,857 & 16,57 \\
\hline $\mathbf{9}$ & 3,774 & 1,152 a 6,036 & 0,084 a 7,464 & 18,84 \\
\hline 11 & 4,490 & 2,184 a 6,796 & 0,658 a 8,322 & 9,20 \\
\hline 13 & 4,960 & 2,654 a 7,266 & 1,128 a 8,792 & 11,89 \\
\hline 15 & 4,950 & 2,379 a 7,521 & 0,177 a 9,723 & 3,37 \\
\hline 17 & 5,158 & 0,855 a 9,461 & $-8,931$ a 19,247 & 4,98 \\
\hline 19 & 5,420 & 1,317 a 8,393 & $-6,529$ a 13,155 & 3,74 \\
\hline
\end{tabular}

